Yordanka Medina Armenteros

\title{
AVALIAÇÃO DA RESPOSTA IMUNE CONTRA AS PROTEÍNAS L E G DO VÍRUS RESPIRATÓRIO SINCICIAL HUMANO
}

Tese apresentada ao programa de Pós-graduação em Microbiologia, do Instituto de Ciências Biomédicas da Universidade de São Paulo, para a obtenção do Título de Doutor em Microbiologia. 


\section{AVALIAÇÃO DA RESPOSTA IMUNE CONTRA \\ AS PROTEÍNAS L E G DO \\ VÍRUS RESPIRATÓRIO SINCICIAL HUMANO}

Tese apresentada ao programa de Pósgraduação em Microbiologia, do Instituto de Ciências Biomédicas da Universidade de São Paulo, para a obtenção do Título de Doutor em Microbiologia.

Área de concentração: Microbiologia

Orientador: Prof. Dr. Armando Morais Ventura

Versão original

São Paulo

2012 
DADOS DE CATALOGAÇÃO NA PUBLICAÇÃO (CIP)

Serviço de Biblioteca e Informação Biomédica do

Instituto de Ciências Biomédicas da Universidade de São Paulo

reprodução não autorizada pelo autor

Medina-Armenteros, Yordanka.

Avaliação da resposta imune contra as proteínas $L$ e $G$ do vírus respiratório sincicial humano / Yordanka Medina Armenteros. -- São Paulo, 2012.

Orientador: Prof. Dr. Armando Morais Ventura.

Tese (Doutorado) - Universidade de São Paulo. Instituto de Ciências Biomédicas. Departamento de Microbiologia. Área de concentração: Microbiologia. Linha de pesquisa: Virologia molecular

Versão do título para o inglês: Evaluation of the immune response against $L$ and $G$ proteins from human respiratory syncytial virus.

1. Virologia 2. Vírus de RNA 3. Vacinas 4. Epítopos I. Ventura, Prof. Dr. Armando Morais II. Universidade de São Paulo. Instituto de Ciências Biomédicas. Programa de Pós-Graduação em Microbiologia III. Título. 
Candidato(a): $\quad$ Yordanka Medina Armenteros.

Título da Tese: $\quad$ Avaliação da resposta imune contra as proteínas $L$ e $G$ do vírus respiratório sincicial humano.

Orientador(a): $\quad$ Prof. Dr. Armando Morais Ventura.

A Comissão Julgadora dos trabalhos de Defesa da Tese de Doutorado, em sessão pública realizada a considerou

\section{( ) Aprovado(a) ( ) Reprovado(a)}

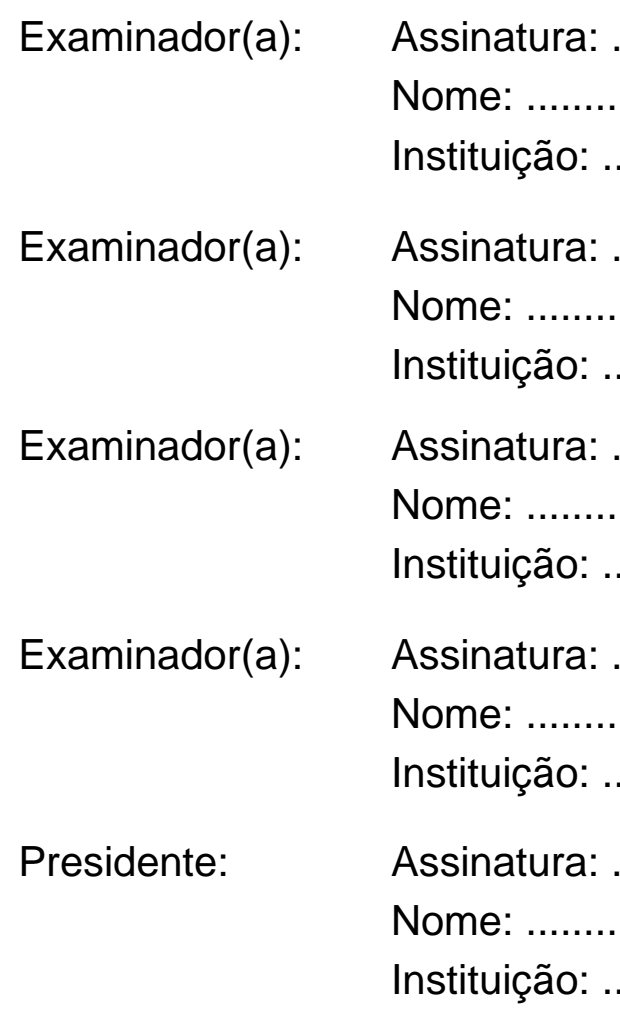




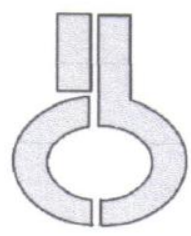

\section{Certificado}

Certificamos que o protocolo registrado sob $\mathrm{n}^{\circ} 018$ nas fls. 42 do livro 2 para uso de animais em experimentação, sob a responsabilidade de Armando Morais Ventura Coordenador(a) da Linha de pesquisa "Avaliação da capacidade imunoprotetora de um peptideo da glicoproteína G do Vírus Respiratório Sincicial Humano" do qual participou(aram) o(s) alunos Yordanka Medina Armenteros, está de acordo com os Principios Éticos de Experimentação Animal adotado pelo Colégio Brasileiro de Experimentação Animal (COBEA) e foi aprovado pela COMISSÃO DE ÉTICA EM EXPERIMENTAÇÃO ANIMAL (CEEA) em 27.02.2007.

São Paulo, 27 de fevereiro de 2007.

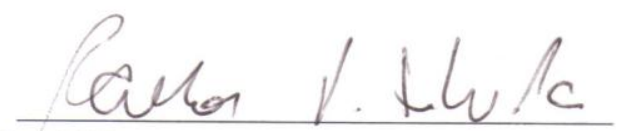

Prof. Dr. Carlos Pelleschi Taborda Vice - Coordenador da CEEA - ICB/USP

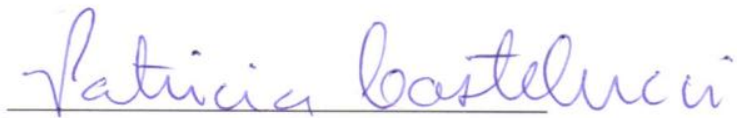

Profa. Dra. PATRÍCIA CASTELUCCI

Secretária da CEEA - ICB/USP 
A minha mãe 


\section{AGRADECIMENTOS}

Agradeço, em primeiro lugar, a Deus que me deu a força para seguir em frente e me tem acompanhado em todos os momentos, bons e ruins, durante minha estadia no Brasil.

A minha família: minha mãe Elisa, minha avo, minhas tias Eva e Lina, minha irmã Ludmila, meu pai Ricardo, Tatá, meus primos Yoan e Anorys, e tem mais... A cada um deles, lhes agradeço por ter me educado, pelos valores passados, por me ensinar a viver, pelo apoio incondicional e pelo amor. Sem todos esses elementos, não estaria hoje onde estou.

A minha irmã Ludmila pela sua ternura e ser minha maior confidente.

Ao Tomás, a Maria Rosa, e sua família pelo apoio e o amor oferecido, e por se tornarem uma parte importante de minha vida.

A Russell por ser esse amigo maravilhoso e pai postiço; pelas lições de vida e pelo carinho sincero que oferece. Muito obrigada amigo, de coração!

Aos meus amigos da salsa, só gente bonita! A eles por me "suportarem" toda quinta, por tornar minhas semanas mais felizes, por sua amizade, pela cumplicidade. A todos os que estão e aos que passaram, muito obrigada!

A Cristina, por sua compreensão e apoio, por seu carinho e por ter esse dom de psicóloga disfarçado em amizade.

Aos irmãos da igreja Butantã.

Aos professores Mario Politi e Elizabete Vicente, pessoas especiais com uma grande sensibilidade.

Ao Prof. Dr. Armando Morais Ventura por ter me dado a oportunidade de formar parte do seu grupo de pesquisa, pelas experiências e o ensino transmitido, pela paciência, a compreensão e sua amabilidade constante; enfim, por todo o apoio oferecido desde o primeiro dia, muito obrigada!

Aos meus colegas do laboratório Cassiano, Tamura, Fernando, Fabiana, Andressa e Paulo. Obrigada pela convivência, as experiências transmitidas e o apoio.

Ao meu "querido uruguayo", Luis: colega, amigo, confidente, irrmaozão. Obrigada pela parceria, pela confidência, por cada momento que você me dedicou e facilitou a minha vida. Por estar sempre atencioso e disposto para ouvir, aconselhar, discordar, elogiar ou criticar. Sem dúvida, uma das melhores pessoas que conheci na minha vida. 
Ao Prof. Dr. Luis Carlos de Souza Ferreira e seu grupo de pesquisa. Em especial a Cariri, Mariana, Rafael, Juliana, Wilson, Robert, Jaime e Loren. Muito obrigada por cada ajuda, dúvida tirada, sorriso ou comentário sem noção capaz de deixar o dia mais errático, um pouco menos triste.

A Catarina pela ajuda no desenvolvimento dos experimentos, pelas experiências transmitidas, a ajuda incondicional; e, sobretudo, por ser amiga.

Ao pessoal do laboratório do Prof. Dr. Carlos F. M. Menck e seu grupo de pesquisa.

Ao nosso técnico Dino, e Carlos do biotério, pelo apoio e as ajudas constantes.

As agências finanaciadoras CNPq e FAPESP.

Ao pessoal da biblioteca, em especial a Tereza e a Eva pela amabilidade e a soliedaridade.

Aos meus amigos cubanos aqui no Brasil e lá em Cuba.

Com certeza vou deixar alguém de fora; para esses, também muito obrigada! 
"Os ventos que às vezes tiram algo que amamos, são os mesmos que trazem algo que aprendemos a amar... Por isso não devemos chorar pelo que nos foi tirado e sim, aprender a amar o que nos foi dado; pois tudo aquilo que é realmente nosso, nunca se vai para sempre...” 


\section{RESUMO}

Medina-Armenteros Y. Avaliação da resposta imune contra as proteínas L e G do Vírus Respiratório Sincicial Humano [tese (Doutorado em Microbiologia)]. São Paulo: Instituto de Ciências Biomédicas da Universidade de São Paulo; 2012.

O desenvolvimento de vacinas pediátricas contra o Vírus Respiratório Sincicial Humano, HRSV (do inglês, Human Respiratory Syncytial Virus), tem sido problemático devido à população alvo envolvida e a dificuldades para atingir um balanço entre atenuação viral e imunogenicidade. Tanto a imunização com a glicoproteína G do HRSV, proteína de ligação ao receptor celular e alvo para a resposta de anticorpos neutralizantes e protetores, quanto a primeira vacina testada inativada com formalina, encontram-se associadas com a indução de eosinofilia pulmonar mediada por uma resposta de células TCD4+ Th2 após exposição ao HRSV selvagem. Foi identificado um peptídeo da proteína $G$, dentro do ectodomínio conservado (aa 184 a 198), que predispõe para essa resposta Th2, sendo que a introdução de mutações eliminou a capacidade desse peptídeo predispor camundongos a desenvolver eosinofilia. Esse achado torna essa seqüência uma ferramenta atraente para o direcionamento da resposta imune protetora contra o vírus HRSV. Células T CD8+ específicas para o epítopo imunodominante encontrado na proteína M2-1 (aa 82 a 90) de HRSV reduzem a resposta Th2 e mediam resistência contra desafio com HRSV quando administrado por via intranasal em camundongos. Em humanos, existe uma relação entre a resposta de linfócitos $\mathrm{T}$ citotóxicos (LTC) contra HRSV e redução dos sintomas clínicos. Assim, a busca de novos epítopos nas proteínas estruturais do vírus é importante. Neste trabalho identificamos epítopos de células TCD8+ na proteína L, a polimerase viral, altamente conservada e a menos estudada nesse aspecto. Essa identificação foi feita por predição utilizando ferramentas de bioinformática, síntese dos peptídeos correspondentes e avaliação da resposta imune celular contra eles, tendo sido demonstrado que L apresenta epítopos de células T restritos pelo H-2 ${ }^{\mathrm{d}}$. Resta caracterizar sua capacidade de proteção frente a desafio com HRSV. Uma segunda abordagem na busca de imunógenos efetivos contra HRSV, consistiu na construção de vacinas de DNA inserindo a sequiência nucleotídica do peptídeo da proteína G mutado (GM, aa164 a 204), mencionado acima. Isso foi feito em vetores de expressão eucariótica em fusão com a seqüência sinal do ativador de plasminogenio tecidual, e com a subunidade B da toxina colérica (CTB), um potente adjuvante de mucosa. Também expressamos e purificamos o peptídeo GM em fusão com CTB, a partir de um vetor bacteriano. A caracterização da resposta imune contra HRSV estimulada por esses vetores eucarióticos e peptídeos purificados revelou que o plasmídio pTGMCTB, bem como as proteínas GM e GMCTB foram capazes de induzir resposta de anticorpos contra GM. Esses anticorpos, porém, não se mostraram neutralizantes de HRSV, como era nossa expectativa. A capacidade de proteção frente a desafio com HRSV não foi demonstrada, porém nenhum destes imunógenos induziu esosinofilia pulmonar. Concluímos que o peptídeo GM não adquire uma conformação adequada capaz de gerar anticorpos neutralizantes, quando está em fusão com a proteína CTB, tanto na forma de proteína, quanto como vacina de DNA.

Palavras-chave: Vírus Respiratório Sincicial Humano (HRSV). RNA polimerase. Epítopos de células TCD8+. Predição de epítopos. Glicoproteína G de ligação. Eosinofilia pulmonar. FI-HRSV. Vacina de DNA. 


\begin{abstract}
Medina-Armenteros Y. Evaluation of the immune response against $\mathrm{L}$ and $\mathrm{G}$ proteins from human respiratory syncytial virus [PhD thesis (Microbiology)]. São Paulo: Instituto de Ciências Biomédicas da Universidade de São Paulo; 2012.
\end{abstract}

The development of pediatric vaccines against human respiratory syncytial virus (HRSV) infection has been controversial due to the target population and difficulties in achieving a balance between viral attenuation and immunogenicity. The attachment glycoprotein $\mathrm{G}$ (target for the neutralizing and protective antibody response), as well as a virus formalin-inactivated vaccine, have been associated with pulmonary eosinophilia induction after natural HRSV infection; mediated by an exaggerated TCD4+ Th2 response. A peptide in G protein (aa 184 to 198) within the $G$ conserved ectodomain, was identified as a major contributor for that response since specific mutations on it abrogated the pulmonary eosinophilia. This finding makes that sequence an interesting target to develop a protective immune response against HRSV infection. CD8+ T cells specific to M2-1 (aa 82 to 90), an immunodominant epitope from the second matrix protein, reduce the Th2 response in mice, and mediate protection against HRSV challenge, intranasally administrated. In humans, there is a relationship between HRSV specific cytotoxic T lymphocytes (CTL) and symptom-reduction. Thus, searching for new epitopes in the structural proteins is very important. In the present work, we identified $\mathrm{CD} 8+\mathrm{T}$ cell epitopes in the structural L protein; the viral polymerase, highly conserved among different strains, and less studied. The identification was made by epitope prediction using bioinformatics; the peptides were synthesized and the cellular immune response against them was tested. It was demonstrated that $\mathrm{L}$ protein contains $\mathrm{H}-2^{\mathrm{d}}$-restricted epitopes. The evaluation of the capacity of these epitopes to protect against HRSV challenge remains to be done. A second approach searching for effective immunogens against HRSV infection was the construction of DNA vaccines. The nucleotide sequence of a peptide derived from $\mathrm{G}$ mutated (GM, aa 164 to 204), mentioned above, was cloned in eukaryotic vectors fused to the tissue plasminogen activator plus the cholera toxin B subunit, a potent mucosal adjuvant. We also expressed and purified the GM peptide in fusion with CTB from a bacterial vector. The characterization of the immune response against HRSV induced by those eukariotic vectors and purified peptides showed that the pTGMCTB plasmid, as well as GM and GMCTB proteins were able to elicit antibodies against GM. These antibodies, however, were not able to neutralize the virus. The protective capacity against HRSV challenge was not demonstrated; however, none of these immunogens induced pulmonary eosinofilia. We conclude that GM peptide did not acquire the proper folding to induce the raising of neutralizing antibodies when fused to CTB, presented as a protein or as a DNA vaccine.

Keywords: Human Respiratory Syncytial Virus (HRSV). RNA polymerase. TCD8+ cells eptitopes. Epitope prediction. Attachment G glycoprotein. Pulmonary eosinofilia. FI-HRSV. DNA vaccine. 


\section{LISTA DE ILUSTRAÇÕES}

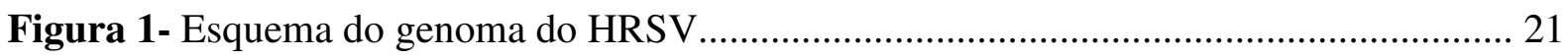

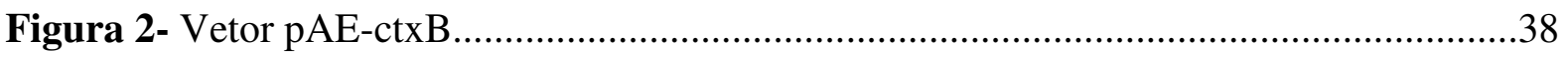

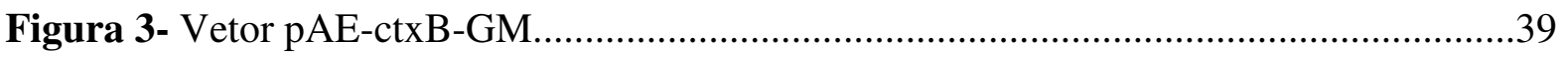

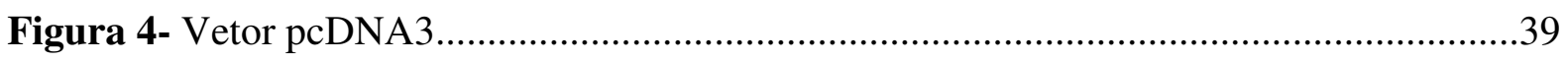

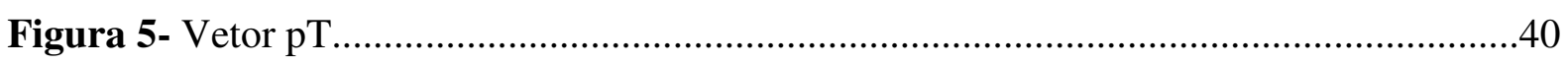

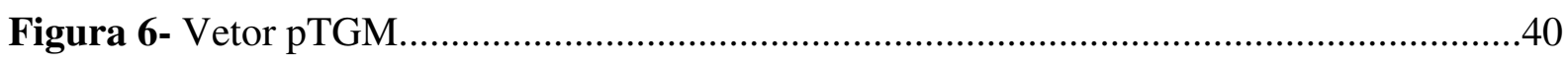

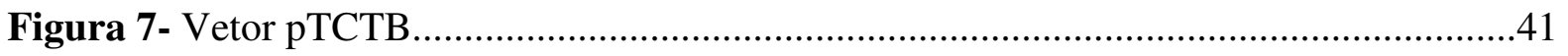

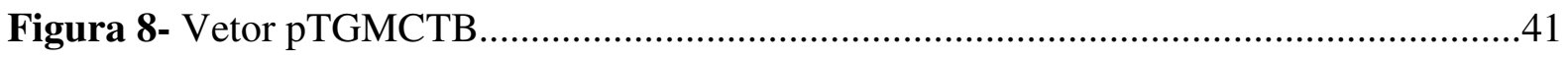

Figura 9- Esquema de ensaio de imunização com peptídeos................................................53

Figura 10- Esquema de ensaio de imunização intraperitoneal............................................61

Figura 11- Esquema de ensaio de imunização intranasal..................................................62

Figura 12- Esquema de imunização com DNA................................................................63

Figura 13- Imunofluorescência de células HEp-2 infectadas.............................................67

Figura 14- Esquema da distribuição das seqüências selecionadas

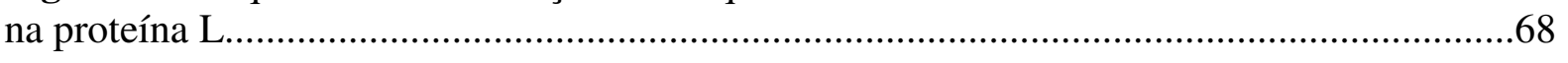

Figura 15- Resposta de liberação de IFN- $\gamma$ após imunização com peptídeos.........................70

Figura 16- Análise da replicação viral por Western Blot ...................................................71

Figura 17- Resposta de liberação de IFN- $\gamma$ no baço.........................................................72

Figura 18- Resposta de liberação de IFN- $\gamma$ nos pulmões...................................................73

Figura 19- Resposta de IFN- $\gamma$ nos ensaios ELISPOT e ICS, após imunização com os peptídeos escolhidos

Figura 20- Resposta de liberação de IFN- $\gamma$ após imunização com peptídeos de 9- mer. 
Figura 21- Resposta de liberação de IFN- $\gamma$ na infecção viral contra os peptídeos de 9-mer.

Figura 22- Análise das proteínas CTB e GMCTB purificadas.

Figura 23- SDS-PAGE das proteínas CTB e GMCTB concentradas.

Figura 24- ELISA dos soros de animais imunizados via intraperitoneal com as proteínas baseadas em GM.

Figura 25- ELISA dos soros de animais imunizados via intranasal com as proteínas baseadas em GM.

Figura 26- ELISA da saliva de animais imunizados via intranasal com as proteínas baseadas em GM.

Figura 27- Ensaio de neutralização do HRSV.

Figura 28- Carga viral em animais imunizados via intraperitoneal com proteínas baseadas em GM.

Figura 29- Histopatologia de pulmões de animais imunizados via intraperitoneal com proteínas baseadas em GM, após desafio

Figura 30- Obtenção do plasmídio pT

Figura 31- Obtenção dos plasmídios pTGM, pTCTB e pTGMCTB

Figura 32- Detecção das proteínas recombinantes por imunofluorescência..

Figura 33- ELISA anti-GM dos soros de animais imunizados com vacinas de DNA.

Figura 34- ELISA anti-CTB dos soros de animais imunizados com vacinas de DNA.

Figura 35- Carga viral em animais imunizados via intramuscular com vacinas de DNA.

Figura 36- Histopatologia de pulmões de animais imunizados com vacinas de DNA após desafio. 


\section{LISTA DE TABELAS}

Tabela 1 - Lista das seqüências da proteína L utilizadas...................................................52

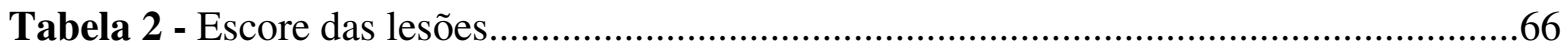

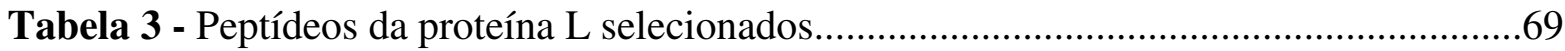

Tabela 4 - Peptídeos de 9-mer dentro das seqüências selecionadas.....................................77

Tabela 5 - Histopatologia dos pulmões de animais imunizados

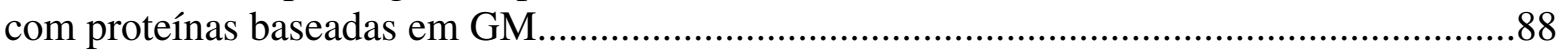

Tabela 6 - Histopatologia de pulmões de animais imunizados com plasmídios .96

Tabela 7 - Escore de ligação ao MHC-I dos epítopos de células TCD8 identificados. 


\section{LISTA DE ABREVIATURAS E SIGLAS}

aa - aminoácidos

Amp - Ampicilina

APC - célula apresentadora de antígeno

ATCC - American Type Culture Collection

BSA - Albumina de soro bovino

CD - células dendríticas

CFA - adjuvante completo de Freund

CMV - Citomegalovírus

CTB - subunidade B da toxina colérica

C-terminal - carboxilo terminal

DAB - 3’3'diaminobenzidina

DEPC - Dietilpirocarbonato

DNA - Deoxyribonucleic Acid

cDNA - DNA complementário

dNTPs - desoxirribonucleotídeos trifosfatos

DO - Densidade óptica

EDTA - ácido etilenodiaminotetracético

ELISA - Enzyme-Linked ImmunoSorbent Assay

ELISPOT- Enzyme-Linked ImmunoSpot

FI-HRSV - Vacina contra HRSV inativada com formalina

GM - peptídeo GM

GM1- receptor gângliosídeo GM1

GMCTB - proteína de fusão, peptídeo GM e a subunidade B da toxina colérica

$\mathrm{h}-$ hora

$\mathrm{H}-2^{\mathrm{d}}$ : haplotipo da molécula MHC-I do camundongo Balb/c

His - histidina

HRSV - Vírus respiratório sincicial humano

ICS - Intracellular cytokine staining

IFA - adjuvante incompleto de Freund

IFN - Interferon

IgG - Imunoglobulina $\mathrm{G}$

IL - interleucina

IPTG - isopropil-beta-D-tiogalactopiranosídeo 
LTC - Linfócitos T CD8+ citotóxicos

MEM- Modified Eagle Medium

MHC-I - major histocompatibility complex class I

MHC-II - major histocompatibility complex class II

min - minutos

MOI - multiplicidade de infecção

$\mathrm{N}$-terminal - extremo amino terminal

$\mathrm{ON}$ - overnight

OPD - ortophenilendiamina

ORF- Open Reading Frame

PAGE- Polyacrylamide gel electrophoresis

$\mathrm{pb}$ - pares de bases

PBS- Phosphate buffered saline

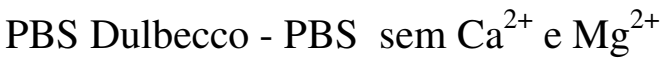

PCR-Polymerase Chain Reaction

RNA - Ribonucleic Acid

rpm - revoluções por minuto

$\mathrm{RT}$ - transcriptase reversa

SDS - duodecil sulfato de sódio

seg - segundos

SFB - soro fetal bovino

SV 40 - Simian virus 40

TA - Temperatura ambiente

TBE - tampão Tris-borato-EDTA

Th1 - T helper 1

Th2 - T helper 2

TLRs - Toll like receptors

TpA - ativador de plasminogênio tecidual

Tris - Tris(hidroximetil)aminometano

rVV-G - vírus vaccinia recombinante expressando a glicoproteína $\mathrm{G}$ 


\section{LISTA DE SÍMBOLOS}

\section{AMINOÁCIDOS}

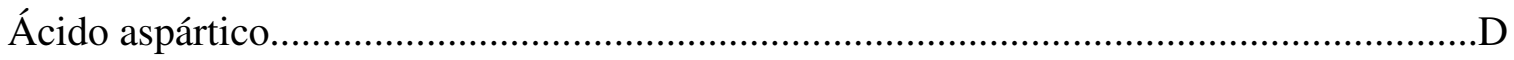

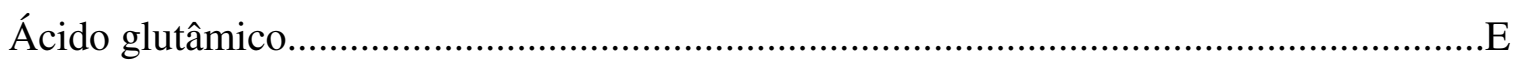

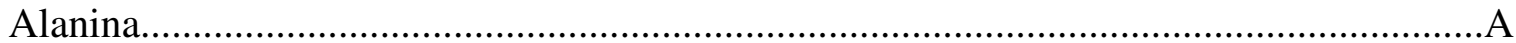

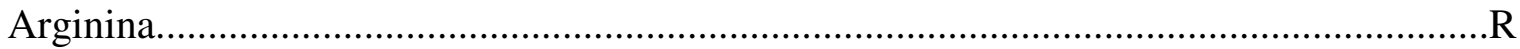

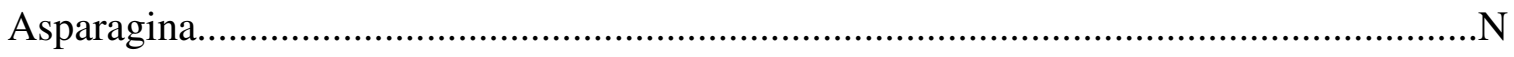

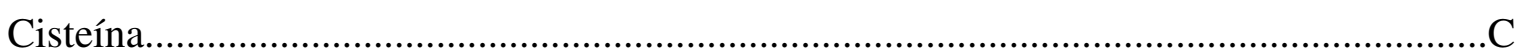

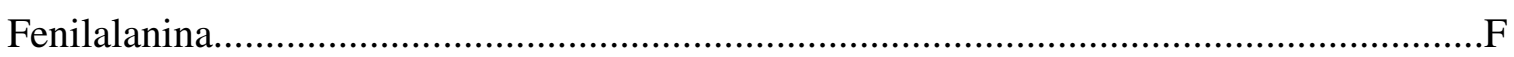

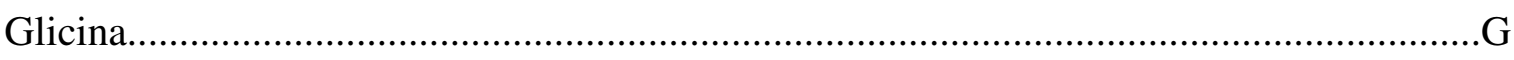

Glutamina

Histidina

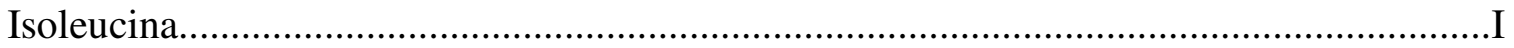

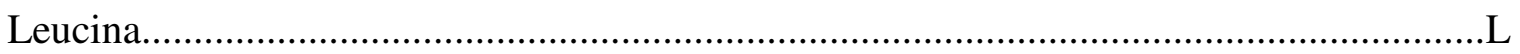

Lisina

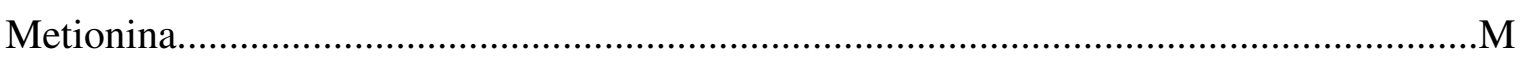

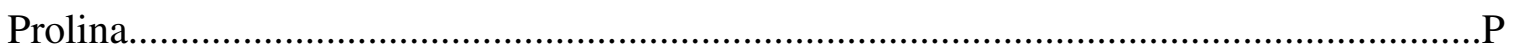

Serina

Tirosina

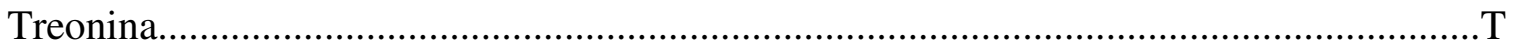

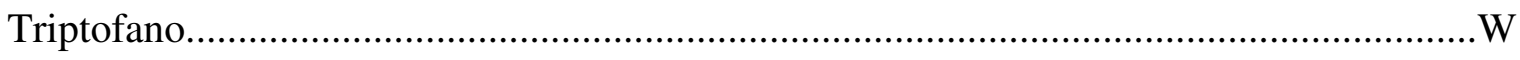

Valina

\section{BASES NITROGENADAS}

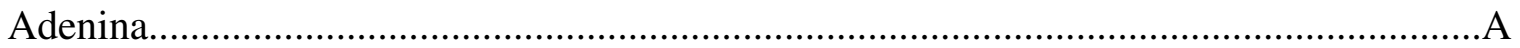

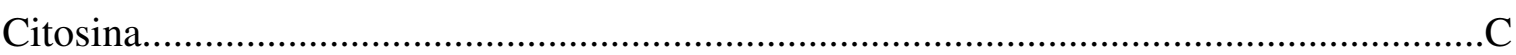

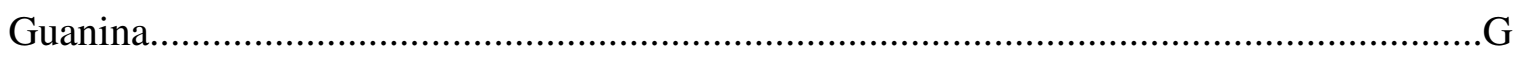

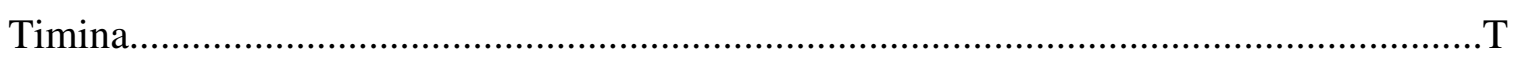




\section{SUMÁRIO}

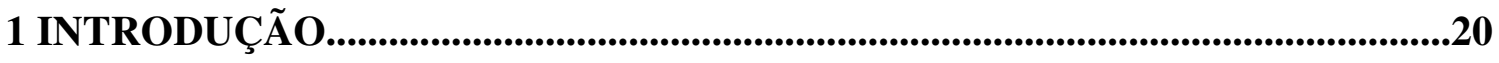

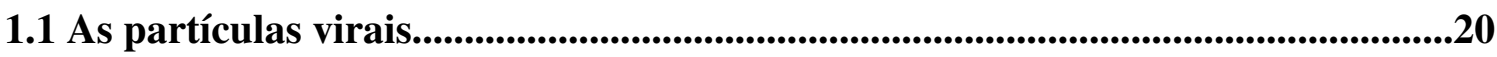

1.2 Genôma do HRSV .............................................................................................................................21

1.3 A glicoproteína G.......................................................................................................22

1.4 RNA polimerase RNA dependente (proteína L).....................................................23

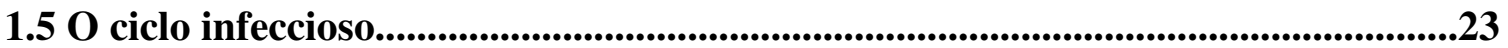

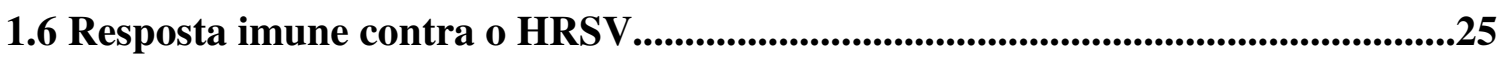

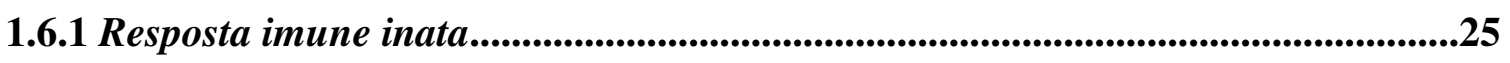

1.6.2 Resposta imune adquirida ...........................................................................................26

1.6.2.1 Resposta imune humoral...............................................................................................27

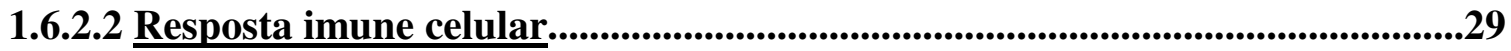

1.7 Papel da resposta imune na patogênese da infecção pelo HRSV ............................32

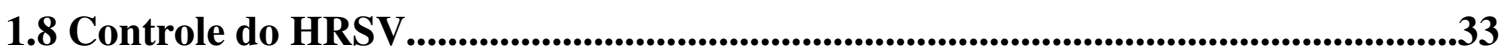

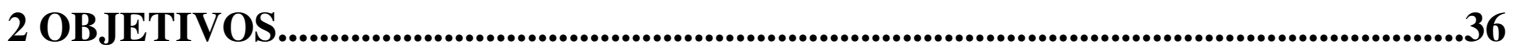

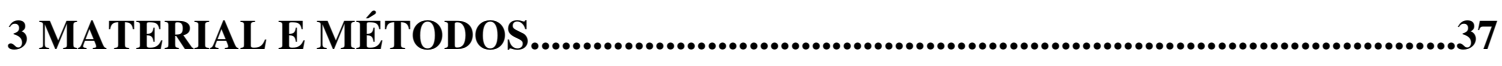

3.1 Metodología Geral............................................................................................................37

3.1.1 Linhagens celulares bacterianas....................................................................................37

3.1.2 Linhagens celulares eucariotas............................................................................37

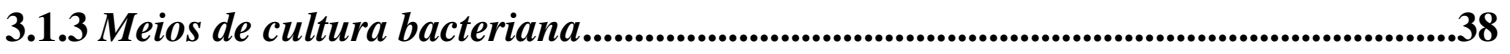

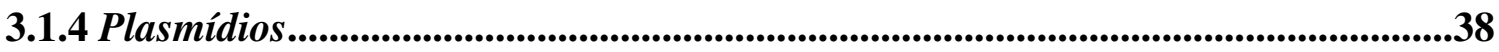

3.1.4.1 Vetores de expressão bacterianos.....................................................................38

3.1.4.2 Vetores de expressão em eucariotos....................................................................................39

3.1.5 Oligonucleotídeos................................................................................................................................42

3.1.6 Preparo de células eletro competentes....................................................................43

3.1.7 Eletro transformação de bactérias competentes......................................................44

3.1.8 Extração de plasmídio em pequena escala (Mini-preparação)..............................44

3.1.9 Purificação de DNA plasmidial em grande escala ....................................................45

3.1.10 Reação em cadeia da polimerase (PCR)..........................................................46

3.1.11 Protocolo de precipitação de DNA........................................................................................46

3.1.12 Seqüenciamento..............................................................................................................47

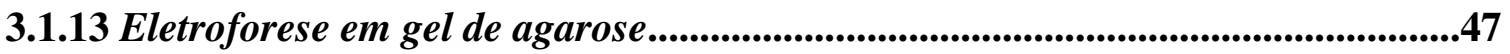


3.1.15 Ensaio Western Blot.............................................................................................48

3.1.16 Obtenção de pó cetônico.........................................................................................49

3.1.17 Adsorção de soros.........................................................................................................................49

3.1.18 Imunofluorescência.......................................................................................................49

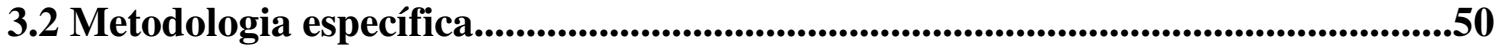

3.2.1 Amplificação dos estoques virais e titulação................................................................50

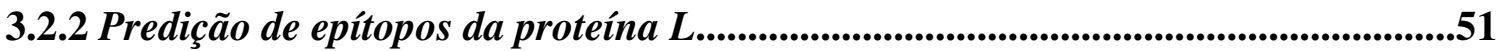

3.2.3 Avaliação da resposta imune celular....................................................................52

3.2.3.1 Imunização de camundongos...............................................................................52

3.2.3.2 Isolamento do vírus do pulmão............................................................................................53

3.2.3.3 Obtencão de células do baco..........................................................................................54

3.2.3.4 Obtencão de células do pulmão $\ldots$..............................................................................54

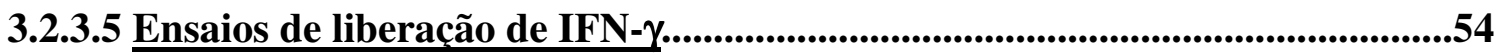

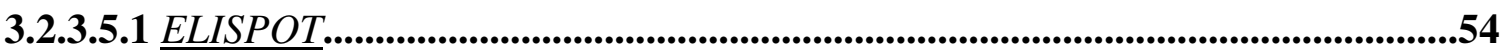

3.2.3.5.2 Marcação intracelular de citocina......................................................................55

3.2.4 Produção de proteínas recombinantes........................................................................56

3.2.4.1 Expressão e purificacão de proteínas.......................................................................56

3.2.4.2 Deteccão de proteínas por Western Blot.................................................................57

3.2.4.3 Análise da funcionalidade de CTB e GMCTB....................................................57

3.2.4.4 Concentração de proteínas.............................................................................................58

3.2.5 Obtenção das vacinas de DNA .....................................................................................58

3.2.5.1 Obtenção do plasmídio pT.................................................................................58

3.2.5.2 Obtencão dos plasmídios pTGM, pTCTB e pTGMCTB.....................................59

3.2.5.3 Ensaio de transfecção

3.2.6. Esquemas de imunização............................................................................................60

3.2.6.1 Imunizacão com proteína...........................................................................................60

3.2.6.1.1 Via intraperitoneal............................................................................................60

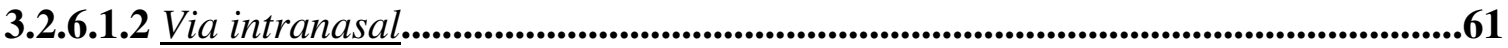

3.2.6.2 Imunizacão com vacinas de DNA...................................................................62

3.2.7 ELISA ..........................................................................................................................63

3.2.8 Ensaio de neutralização ..........................................................................................64

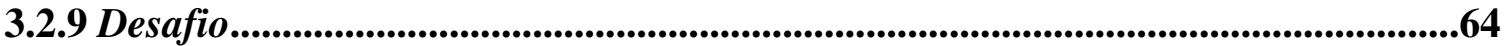

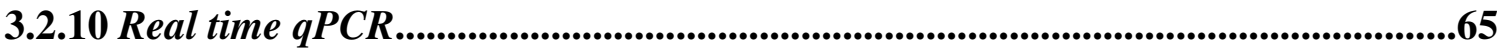


3.2.10.1 Extracão de RNA......................................................................................................65

3.2.10.2 Síntese de cDNA....................................................................................................65

3.2.10.3 Reacão de real time QPCR .....................................................................................66

3.2.11 Análise histopatológica...........................................................................................66

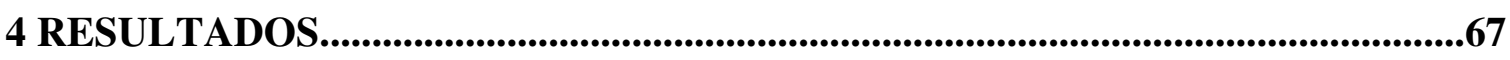

4.1 Obtenção dos estoques de HRSV..................................................................................67

4.2 Seleção de epítopos por predição....................................................................................68

4.3 Análise da resposta imune celular contra os peptídeos da proteína L...................69

4.3.1 Resposta imune celular contra $L$ imunizando com peptídeos...................................69

4.3.2 Resposta imune celular no contexto da infeç̧ão viral................................................70

4.4 Expressão das proteínas recombinantes.......................................................................79

4.4.1 Purificação e análise de CTB e GMCTB..................................................................79

4.4.2 Preparação de proteínas para imunização ...................................................................81

4.5 Análise da imunogenicidade das proteínas baseadas no peptídeo GM...................82

4.5.1 Resposta imune humoral............................................................................................82

4.5.2 Resposta imune protetora...............................................................................................85

4.5.2.1 Ensaio de neutralização........................................................................................85

4.5.2.2 Carga viral.............................................................................................................85

4.5.2.3 Análise histopatológica...................................................................................................88

4.6 Obtenção das vacinas de DNA (pT, pTGM, pTCTB e pTGMCTB)........................89

4.6.1 Análise da expressão dos vetores plasmidiais pTGM, pTCTB $e$

pTGMCTB ............................................................................................................................92

4.6.2 Análise da imunogenicidade das vacinas de DNA...................................................93

4.6.2.1 Resposta imune humoral.........................................................................................93

4. 6.2.2 Resposta imune protetora............................................................................................94

4. 6.2.2.1 Carga viral ................................................................................................99

4. 6.2.2.2 Análise histopatológica.......................................................................................95

5 DISCUSSÃO

5.1 Predição de epítopos na proteína L............................................................................97

5.2 Análise da resposta imune celular contra as seqüências da proteína L.................98

5.3 Análise da resposta imune contra o peptídeo GM...................................................100

6 CONCLUSÕES....................................................................................................................104

REFERÊNCIAS............................................................................................105 


\section{INTRODUÇÃO}

O HRSV é o principal patógeno viral respiratório em crianças e bebês mundialmente. A infecção pode causar sintomas leves como resfriado comum, otite ou rinite; ou mais graves como bronquiolite, traqueobronquite e pneumonia (Paramore et al., 2004). Estima-se que 50\% das crianças contraem o HRSV durante o primeiro ano de vida, e que $100 \%$ delas experimentou pelo menos uma infecção antes dos três anos de idade. A infecção provocada pelo vírus não induz imunidade protetora vitalícia, sendo que as reinfecções são freqüentes em todas as idades (CDC, 2004; Falsey et al., 2005).

O HRSV é um vírus envelopado classificado na ordem Mononegavirales, família Paramixoviridae, subfamília Pneumovirinae, gênero pneumovírus (Collins et al., 2001). O HRSV foi isolado pela primeira vez de um chimpanzé com coriza e dois anos mais tarde de duas crianças com doença respiratória (Chanock et al., 1957). O HRSV subdivide-se em dois grupos antigênicos, A e B (Anderson et al., 1985; Mufson et al., 1985), que se correlacionam com vírus diferentes geneticamente (Cristina et al., 1990).

\subsection{As partículas virais}

As partículas virais de HRSV são heterogêneas em tamanho e forma. Quando observadas no microscópio eletrônico, são identificados dois tipos: (i) arredondadas ou em forma de rim de 150-250nm, e (ii) filamentosas de até $10 \mu \mathrm{m}$ de comprimento (Bâchi e Howe, 1973).

As partículas virais são envoltas por uma bicamada lipídica (envelope) derivada da membrana plasmática da célula hospedeira, na qual são inseridas três glicoproteínas: a glicoproteína G, responsável pela ligação do vírus ao receptor celular (Levine et al., 1987); a glicoproteína F que media a fusão das membranas celular e viral (Walsh e Hruska, 1983); e a proteína hidrofóbica SH. As glicoproteínas F e G formam as espículas características observadas à microscopia eletrônica, enquanto a SH é expressa abundantemente na superfície de células infectadas com o vírus, mas é incorporada apenas em baixas quantidades nas partículas virais (Collins e Mottet, 1993). Logo abaixo do envelope há uma camada de revestimento formada pela proteína $\mathrm{M}$ (de matriz) viral.

No interior da partícula viral, encontramos o nucleocapsídeo que consiste do RNA genômico fortemente ligado à nucleoproteína $\mathrm{N}$, e outras proteínas: a L, subunidade principal 
da polimerase viral; a P, uma fosfoproteína que é subunidade da polimerase; e a M2-1, um fator de anti terminação de transcrição.

O genoma de HRSV codifica três proteínas não estruturais (NS1, NS2 e M2-2) que são produzidas nas células infectadas mas não são incorporadas nas partículas virais (Melero, 2007). NS2 inibe a resposta de interferon (IFN) tipo I (Ramaswamy et al., 2006), NS1 e NS2 inibem a apotose (Bitko et al., 2007), enquanto M2-2 especula-se ser responsável por estimular a replicação viral e inibir a transcrição viral (Collins et al., 2001).

\subsection{Genôma do HRSV}

O genôma é uma molécula de RNA fita simples de sentido negativo de $15.2 \mathrm{~Kb}$. Esse RNA (figura 1) codifica para 10 genes que são transcritos seqüencialmente a partir da extremidade 3' pela polimerase viral produzindo 10 RNAs mensageiros. Os genes são organizados linearmente ao longo do genoma, separados por seqüências intergênicas variáveis, exceto os dois últimos genes (M2 e L) que se sobrepõe por 68 nucleotídeos. A transcrição de cada mRNA é guiada por essas pequenas seqüências que flanqueiam cada gene (Collins e Murphy, 2005).

Figura 1 - Esquema do genoma do HRSV.

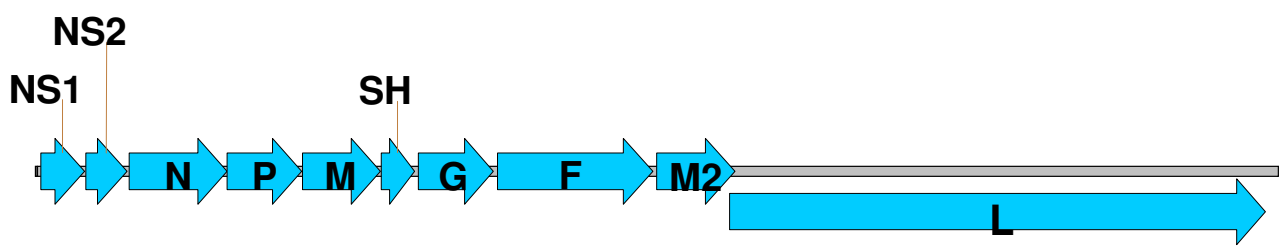

RSV A2

15219 bp

Fonte: Modificado de Collins e Murphy (2005)

No extremo 3' do RNA viral se encontra uma seqüência leader de 44 NT, bem conservada, que contém o promotor para a transcrição do RNA e a síntese do antigenoma; enquanto o extremo $5^{\prime}$ é caracterizado por uma seqüência trailer de $155 \mathrm{NT}$, altamente heterogênea, que contem o promotor para a síntese do genoma da progênie (Mink et al., 1991). 


\subsection{A glicoproteína G}

A proteína $\mathrm{G}$ é uma glicoproteína transmembrana do tipo II constituída por um domínio citoplasmático $\mathrm{N}$ terminal, uma região hidrofóbica (domínio transmembrana) e um ectodomínio (porção extra citoplasmática). Há duas regiões hipervariáveis no "ectodomínio", separadas por uma sequiência conservada de 13 aa, sendo que o domínio localizado perto da região carboxilo terminal (C-terminal) da proteína $\mathrm{G}$ reflete toda a variabilidade do gene $\mathrm{G}$ (Martínez et al., 1999). Estas regiões hipervariáveis são altamente glicosiladas, com açúcares acoplados por ligações do tipo $\mathrm{N}$ ou $\mathrm{O}$ que reduzem a antigenicidade cobrindo a proteína viral com açúcares específicos da célula (Garcia-Barreno et al., 1994; Hall, 2000). Estas modificações aumentam a massa molar da proteína para 80-90 kDa em SDS-PAGE (Melero, 2007). De fato a glicoproteína $G$ é a proteína de envelope mais variável, sendo os HRSVs classificados em grupo A ou B, dependendo de sua reatividade com um padrão de anticorpos monoclonais dirigidos contra ela (Anderson et al., 1985; Mufson et al., 1985). A sequiência de 13 aa que abrange os resíduos 173-186 contém quatro cisteínas (173, 176, 182 e 186), é conservada entre todas as amostras virais humanas, sendo candidata a sítio de ligação ao receptor. As pontes disulfetos são formadas entre Cys 173 e 186, e 176 e 182. Uma seqüência pequena localizada entre os resíduos 184-198, perto do motivo conservado de Cys, tem sido identificada como a responsável pela ligação da proteína $\mathrm{G}$ a glicosaminoglicanos (GAGs) da superfície celular (Feldman et al., 1999). A região central conservada do ectodomínio, contem epítopos que são tanto mantidos em todos os isolados de HRSV (epítopos conservados), quanto compartilhados por vírus do mesmo grupo antigénico (epítopos específicos de grupo) (Martínez et al., 1997; Melero et al., 1997).

A proteína $\mathrm{G}$ é produzida de duas formas nas células infectadas. A primeira, associada a membrana (Gm) de 292-319 aa, dependendo da cepa viral, é a forma completa, incorporada ao virion. A segunda forma observada (Roberts et al., 1994) é secretada (Gs), e gerada a partir da iniciação da tradução em um códon AUG interno que está na mesma ORF usada para produzir a proteína completa (Johnson et al., 1998; Johnson e Graham,1999). Atualmente não se conhece o papel de Gs, porém algumas pesquisas têm revelado que Gs pode agir como uma "isca" para anticorpos ou ter algum efeito imunomodulatório in vivo (Polack et al., 2005). Vírus que expressam apenas Gs multiplicam-se eficientemente em cultura de células, e são atenuados apenas moderadamente in vivo (Teng et al., 2001). 


\subsection{RNA polimerase RNA dependente (proteína $L$ )}

A proteína L está no complexo ribonucleoprotéico encontrado no virion de HRSV. A polimerase viral é formada por duas subunidades, L é a que contém o sítio ativo de polimerização e demais atividades enzimáticas, e $\mathrm{P}$ age como uma espécie de fator de transcrição. Dessa forma, passaremos a nos referir a L como sendo a polimerase. Ela é uma proteína de 2165 aa, de aproximadamente $250 \mathrm{kDa}$, e é a menos abundante das proteínas estruturais. A predição de sua sequiência aminoacídica indica um alto conteúdo de leucinas e isoleucinas (21.9\% combinados). Seqüências de proteínas L de Mononegavirales foram alinhadas permitindo a identificação de seis regiões (I a VI) relativamente conservadas. O maior grau de conservação é concentrado principalmente na metade $\mathrm{N}$ terminal do polipeptídeo (aas 422-938), incluindo a região III que contém quatro motivos característicos de polimerases (Poch et al., 1989; 1990).

Dentre as funções atribuídas à proteína L estão, além de ser uma RNA polimerase RNA dependente, fazer a poliadenilação (Stec et al., 1991) e a adição do CAP nos mRNAs virais (Ferron et al., 2002). Das proteínas do HRSV, ela pode ser considerada uma das menos estudadas, havendo pouca informação sobre suas características imunogênicas e estruturais.

\section{$1.5 \mathrm{O}$ ciclo infeccioso}

A entrada na célula hospedeira ocorre em dois passos bem diferenciados: 1) ligação do vírus a componentes da superfície celular (receptor), e 2) fusão das membranas viral e celular. A glicoproteína $\mathrm{G}$ media o primeiro passo, seguido pela ativação da proteína $\mathrm{F}$ que promove a fusão.

Como foi mencionado anteriormente, acredita-se que a proteína $\mathrm{G}$ media a ligação das partículas de HRSV à superfície da célula hospedeira (Levine et al., 1987), porém ela não é requerida para a infecção de alguns tipos celulares em cultura de tecidos. Assim, tem sido reportado que vírus que carecem da proteína $\mathrm{G}$ são capazes de se replicar in vitro, embora são atenuados in vivo (Karron et al., 1997; Teng et al., 2001). Isto sugere a existência de vias alternativas independentes de Gm. Neste sentido foi demonstrada a interação do HRSV com a nucleolina, componente da célula hospedeira, através da proteína $\mathrm{F}$ de fusão. O silenciamento do gene codificando para nucleolina pulmonar por RNAi foi associado com uma redução significativa da infecção viral em camundongos, confirmando que a nucleolina é um receptor funcional de HRSV, in vivo. No entanto, o uso da nucleolina como receptor não explica o 
tropismo específico do vírus, sendo que a nucleolina é expressa em muitos tecidos, na superfície de muitos tipos celulares (Tayyari et al., 2011).

A transcrição e a replicação viral ocorrem no citoplasma da célula hospedeira. Após a internalização do nuclecapsídeo viral no citoplasma, ativa-se a transcrição seqüencial do genoma viral para gerar um grupo de mRNAs. Estes mRNAs carregam a informação necessária para serem traduzidos pelos ribossomos, produzindo os produtos gênicos correspondentes. Eventualmente esses produtos se acumulam perto da membrana celular onde são montados nas partículas virais novas. A transcrição requer a ação coordenada de quatro proteínas virais: L, P, N e M2-1. Num determinado momento após infecção, há uma mudança na síntese do RNA, de transcrição para replicação; esta mudança precisa da ação da proteína M2-2. A replicação requer N, P e L, mas não M2-1 e envolve a síntese de uma cópia do genoma viral (vRNA) completo de polaridade oposta (cRNA) ou antigenoma. O antigenoma também forma complexos com a proteína $\mathrm{N}$ e ele serve de molde para a síntese do genoma viral da progênie (Melero, 2007).

As partículas virais montadas são liberadas das células infectadas por brotamento através da membrana plasmática celular adquirindo assim, o envelope onde se encontram as glicoproteínas G, SH, e F (Collins et al., 2001). A proteína estrutural M tem um papel duplo no processo de morfogênese do vírus. Ela se liga aos nucleocapsídeos para torná-los transcricionalmente inativos, e também media a associação deles com o envelope viral nascente (Melero, 2007).

O HRSV induz um efeito citopático tardio em células permissivas, comparado com outros vírus líticos, e um desligamento moderado da síntese de proteínas na célula infectada (García-Barreno et al., 1988). Ele pode se replicar e produzir progênie viral infecciosa em células sem núcleo (Follet et al., 1975), indicando que os diferentes passos do ciclo replicativo não requerem funções nucleares ativas. Porém, o HRSV altera a expressão de inúmeras citocinas e quimiocinas em células epiteliais e outros tipos celulares. Acredita-se que a produção de quimiocinas pelas células epiteliais infectadas com HRSV seja o principal determinante da resposta inflamatória que influencia a severidade da infecção (Hoffman et al., 2004). 


\subsection{Resposta imune contra o HRSV}

\subsubsection{Resposta imune inata}

Um dos mecanismos pelos quais o sistema imune inato identifica a invasão de um microorganismo é através dos Toll like receptors (TLRs). Eles constituem uma família de receptores tipo I que reconhecem padrões moleculares específicos presentes em componentes microbianos (PAMPs). A infecção por HRSV incrementa a expressão de TLR4 em células epiteliais das vias aéreas onde este receptor é normalmente expresso em baixo nível (Monick et al., 2003).

Foi observado que a proteína F é reconhecida por TLR4 e CD14 presentes em monócitos humanos (Kurt-Jones et al., 2000). Esta interação conduz à ativação de NF-KB e à produção de mediadores anti microbianos pró-inflamatórios tais como TNF- $\alpha$, IL-6 e IL-12. Apesar desta ativação existem evidências de que a região rica em cisteina da proteína $\mathrm{G}$ pode suprimir a produção de citocinas, mediada por TLR4 em macrófagos e monócitos, inibindo a translocação nuclear de NF-KB (Polack et al., 2005). O mecanismo pelo qual a proteína G media esse efeito é desconhecido, no entanto, a região rica em cisteínas de G apresenta homologia com o quarto domínio do receptor de TNF (Langedijk et al., 1998). Isto sugere que a forma solúvel Gs, secretada bem cedo na infecção antes da progênie viral ser liberada, pode mediar o efeito inibitório se ligando a TNF alfa.

TLR3 é expresso em células epiteliais bronquiais e detecta RNA de dupla fita (dsRNA) (Alexopoulou et al., 2001). A infecção por HRSV ativa a expressão de TLR3, além disso, existem evidências de que a replicação do vírus induz quimiocinas como RANTES (CCL5) pela via de sinalização de TLR3. Alguns estudos sugerem que TLR3 não é necessário para a eliminação dos vírus, porém, é necessário para manter um ambiente imune que evite o desenvolvimento da patologia pulmonar mediada pela resposta Th2 (Melero, 2007).

Uma das primeiras respostas das células frente à infecção viral é a produção de IFN $\alpha / \beta$. HRSV é resistente a esse efeito antiviral (Atreya e Kulkarni, 1999; Schlender et al., 2000). NS1 e NS2 agem cooperativamente para interromper a atividade antiviral do IFN e prevenir a sua indução em células infectadas (Spann et al., 2004).

As proteínas surfactantes (SP) A e D são produzidas por células epiteliais das vias respiratórias e são moléculas de reconhecimento de PAMPs, que formam a primeira linha de defesa contra infecções no pulmão. Durante a infecção severa com HRSV os níveis das proteínas A e D no lavado bronquioalveolar estão reduzidos (Kerr e Paton, 1999). SP-A se 
liga às proteínas F e G, prevenindo a infecção da célula alvo (Ghildyal et al., 1999) e potenciando a opsonização e a captura do HSRV por macrófagos e monócitos (Barre $\mathrm{t}$ al., 2000). SP-D se liga à proteína $\mathrm{G}$ e inibe a infecção de HRSV in vitro e in vivo (Hickling et al., 1999).

As células dendríticas (CD) são células apresentadoras de antígenos (APC) necessárias para a ativação de células T. Estudos sobre a infecção com HRSV em modelos experimentais sugerem que as $\mathrm{CD}$ respiratórias carregam antígenos virais do trato respiratório até os linfonodos onde elas encontram e ativam as células T vírus específicas (de Jong et al., 2005). Esta ativação é diminuída pela infecção das CD pelo HRSV, o que resulta em baixos níveis de proliferação de células $\mathrm{T}$, afetando a produção de citocinas, uma das características das células T regulatórias (Bartz et al., 2003; de Graaff et al., 2005).

As células natural killer (NK) são recrutadas no sítio da infecção onde desenvolvem a sua atividade citotóxica e produzem IFN- $\gamma$ ao reconhecerem as células infectadas. A ativação das NK potencia a ativação de células TCD8+ em linfócitos T citotóxicos (LTC) de memória, e influenciam a diferenciação de células TCD4+ no fenótipo Th1 (Romagnani, 1992; Bancroft, 1993; Kos e Engleman, 1996). Em camundongos Balb/c infectados com HRSV as células NK são recrutadas aos pulmões bem cedo após infecção, atingindo o pico entre os dias três e quatro quando elas representam a fonte principal de IFN- $\gamma$ (Anderson et al., 1989; Hussell e Openshaw, 1998). Após infecção de camundongos Balb/c com um mutante da cepa B $\Delta \mathrm{G} / \mathrm{SH}$ foi observado um grande número de células NK pulmonares comparado com os animais infectados com a cepa selvagem, sugerindo que as proteínas G e /ou SH podem inibir a resposta destas células (Tripp et al., 1999). Aliás, nestes estudos houve um correlato do número incrementado de células com níveis maiores de mRNA de quimiocinas que atraem as células NK ao pulmão nos camundongos infectados com $\Delta \mathrm{G} / \mathrm{SH}$ (Tripp et al., 2000). Isto pode indicar que $\mathrm{G}$ e $\mathrm{SH}$ inibem a resposta de quimiocina desde o início da resposta imune (Polack et al., 2005).

\subsubsection{Resposta imune adquirida}

A resposta imune inata tem um papel importante na patogênese da infecção por HRSV e no estabelecimento da resposta imune adaptativa, enquanto a recuperação da infecção e a resistência à reinfecção são mediadas por componentes do sistema imune adaptativo. Por 
outro lado, cada dia é mais evidente que um balanço entre os diferentes tipos de resposta imune é crucial na determinação do curso da infecção.

\subsubsection{Resposta imune humoral}

Embora a infecção por HRSV induza anticorpos contra uma variedade de proteínas virais, somente aqueles contra as glicoproteínas do envelope F e G neutralizam o vírus e conferem resistência à infecção. A antigenicidade e a imunogenicidade de $\mathrm{F}$ são altamente dependentes do seu enovelamento (Gaddum et al., 1996). A análise do repertório de anticorpos específicos para $\mathrm{F}$ induzidos pela infecção com HRSV demonstrou que os anticorpos altamente neutralizantes reconhecem a proteína madura na superfície celular enquanto que, os poucos neutralizantes reconhecem a forma imatura de F (Sakurai et al., 1999). Anticorpos monoclonais anti-F neutralizantes, capazes de inibir a formação de células gigantes multinucleadas, são altamente efetivos não só prevenindo a infecção de HRSV, mas também eliminando o vírus do pulmão quando administrados terapeuticamente (Taylor et al., 1992; Taylor, 1994). Diferente de F, o reconhecimento de G não parece ser dependente da estrutura enovelada da proteína G (Martínez et al., 1997; Melero et al., 1997). Ela é um dos alvos para a resposta de anticorpos neutralizantes e protetores.

Tanto anticorpos séricos como secretores são produzidos em resposta à infecção por HRSV, inclusive por bebês com menos de seis meses de idade (McIntosh et al., 1978; Richardson et al., 1978; Watt et al., 1986). No entanto, a freqüência e a magnitude da resposta de anticorpos nesses bebês são significativamente menores que em bebês com mais de seis meses de idade, provavelmente devido à combinação da imaturidade imunológica e ao efeito supressor dos anticorpos maternais transmitidos transplacentariamente (Murphy et al., 1986a).

Os anticorpos desempenham um papel na proteção contra a infecção pelo vírus e existe um forte correlato entre os níveis de anticorpos maternais contra HRSV e a resistência à infecção durante as primeiras semanas de vida, quando esses anticorpos apresentam os maiores títulos. A incidência e a severidade da doença do trato respiratório baixo em bebes exibem uma correlação inversa com o nível de anticorpos séricos em sangue de cordão umbilical (Glezen et al., 1981; Ogilvie et al., 1981; Holberg et al., 1991). Em idosos, os níveis de anticorpos neutralizantes também correlacionam inversamente com o risco de hospitalização durante a infecção aguda com HRSV (Falsey e Walsh, 1998).

Embora a administração parenteral de anticorpos monoclonais ou policlonais neutralizantes seja efetiva contra infecção pulmonar com HRSV, a administração intranasal 
de anticorpos mostrou-se pelo menos 160 vezes mais potente (Prince et al., 1987). Estas observações sugerem que os anticorpos produzidos localmente podem ser mais efetivos contra a infecção pulmonar que os anticorpos séricos. A presença de anticorpos nasais neutralizantes contra HRSV está associada com a resistência à reinfecção em humanos (Mills et al., 1971), níveis reduzidos de replicação viral (Chanock et al., 1970) e um bloqueio precoce da replicação viral (Taylor et al., 1990; Hall et al., 1991), o que torna a estimulação da imunidade de mucosa contra esse vírus um aspecto crítico para o desenvolvimento de vacinas antiHRSV. Assim, os níveis altos de anticorpos neutralizantes, em secreções nasais, parecem limitar a replicação viral no trato respiratório superior, independentemente do nível de anticorpos séricos (Mills et al., 1971). Anticorpos IgA secretores são de curta duração comparado com anticorpos séricos, porém a infecção repetida com HRSV induz níveis maiores de IgA e uma resposta mais duradoura (Henderson et al., 1979; Welliver et al., 1980).

O papel dos anticorpos na recuperação da infecção viral é mínimo. A administração parenteral de imunoglobulinas contra HRSV ou o anticorpo monoclonal anti-F humanizado, a bebes hospitalizados com HRSV, reduz os níveis de excreção nasofaríngea do vírus; mas tem um efeito pequeno, ou nenhum efeito, no resultado da infecção. Estudos em camundongos Balb/c depletados de células B mostraram que anticorpos HRSV específicos não são necessários para parar a replicação de HRSV na infecção primária. Contrastando com este achado, experimentos em camundongos nude ( $\mathrm{nu}+/ \mathrm{nu}+)$ e SCID/beige indicaram que o tratamento com anticorpo monoclonal pode efetivamente eliminar o vírus dos pulmões (Taylor, 1994). Embora os dados demonstrem que anticorpos neutralizantes podem mediar a recuperação da infecção, a cinética relativamente baixa e a qualidade pobre da resposta primária de anticorpos sugerem que a contribuição dos anticorpos para a eliminação viral numa infecção primária seja mínima. Contudo, o desenvolvimento de IgA específicas para HRSV correlaciona com a eliminação do vírus da nasofaringe (McIntosh et al., 1978).

Resumindo, os anticorpos são importantes mediadores de proteção contra infecção primária e reinfecções, porém a proteção é incompleta e de curta duração. A imunidade local parece ser importante na proteção do trato respiratório superior, enquanto níveis altos de anticorpos séricos exibem um papel fundamental na resistência à infecção de HRSV no trato respiratório baixo (Taylor, 2007). 


\subsubsection{Resposta imune celular}

Os estudos em camundongos Balb/c escarificados com rVV expressando diferentes proteínas de HRSV têm demonstrado que as proteínas G e F ativam diferentes subgrupos de células TCD4+ (Alwan e Openshaw, 1993; Alwan et al., 1993; Alwan et al., 1994). Assim, a escarificação com rVVF induziu uma resposta de células TCD4 inclinada para o tipo Th1 com a produção de IL-2 e IFN- $\gamma$; enquanto a escarificação com vírus vaccinia recombinante expressando a glicoproteína $\mathrm{G}(\mathrm{rVV}-\mathrm{G})$ induziu uma resposta inclinada para o tipo Th2 com a produção de IL-4, IL-5, IL-13 e IFN- $\gamma$ (Bembridge et al., 1998; Johnson e Graham, 1999).

A infecção de crianças previamente vacinadas com vacina contra HRSV inativada com formalina (FI-HRSV) está associada com a doença exacerbada e eosinofilia pulmonar devido a uma resposta de memória Th2 exagerada. O modelo de camundongo Balb/c de infecção por HRSV reproduz a eosinofilia pulmonar exacerbada observada em humanos (Waris et al., 1996). A imunização desses animais tanto com a vacina inativada quanto a glicoproteína $G$ individualmente induz essa resposta imunopatogênica mediada por células TCD4+, enquanto as vacinas vivas atenuadas estão associadas com resposta Th1 (Connors et al., 1994; Hancock et al., 1996). O uso de mutantes frame-shift da proteína $\mathrm{G}$ permitiu encontrar uma seqüência correspondente aos resíduos 193-203, a qual mostrou ser responsável pela indução de eosinofilia pulmonar em Balb/c (Sparer et al., 1998). A seqüência abrangendo os resíduos 184-198 (AICKRIPNKKPGKKT), também foi identificada como a responsável da predisposição para essa resposta Th2, sendo suficiente para mimetizar a resposta da proteína G integral (Tebbey et al., 1998). Esta região se sobrepõe com a região identificada por Sparer e colaboradores e ela estimula a expansão de um subgrupo de células TCD4+ que expressa V $\beta 14+$ no receptor de células T; secretando IL-5, a citocina responsável pela indução e recrutamento de eosinófilos (Sparer et al., 1998; Tebbey et al., 1998; Johnson et al., 2004b). Mutações introduzidas nesse peptídeo nas posições 187, 189 e 192 (em azul) (AICGRGPNGKPGKKT) eliminaram completamente sua capacidade de predispor os camundongos a desenvolver eosinofilia (Tebbey et al., 1998). A seqüência de aa 184-198 apresenta um motivo entre os resíduos 182-186, que é comum a um tipo de proteína quimioatrativa conhecida como $\mathrm{CX} 3 \mathrm{C}$ citocina fractalina. Tripp e colaboradores demonstraram que a proteína $\mathrm{G}$ se liga ao receptor de CX3C (CX3CR1), fazendo com que a infecção seja facilitada (Tripp et al., 2001). 
Alguns estudos têm demonstrado a presença de epítopos imunodominantes dentro da região 162-179 da proteína $\mathrm{G}$, reconhecidos por células TCD4+ humanas que produzem citocinas Th1 e Th2 (de Graaff et al., 2004; de Waal et al., 2004). Congruente com este resultado, Plotnicky-Guilquin e colaboradores identificaram epítopos de células B murinas implicados na proteção do trato respiratório baixo que mapeiam nas regiões de aa 165-172, 171-187 (com dois epítopos superpostos) e 196-204. A análise por Pepscan de soros humanos soropositivos ao HRSV revelou que todos os epítopos de células B murinas protetores (protectopes) que mapearam no domínio central conservado também foram reconhecidos em humanos (Plotnicky-Guilquin et al., 1999).

A reposta exagerada contra a infecção por HRSV em crianças vacinadas com FI-HRSV pode ser devida ao potenciamento da replicação viral mediada por anticorpos. Crianças vacinadas produziram altos títulos de anticorpos contra F, mas não contra G. Porém, os níveis de anticorpos neutralizantes foram menores que os induzidos em crianças de idade comparável, após infecção viral natural (Murphy et al., 1986b). Isto sugere que os anticorpos induzidos pela FI-HRSV são pobremente neutralizantes, falhando, assim, na proteção contra a infecção viral. Acredita-se que os anticorpos produzidos reagiram com antígenos virais nos pulmões levando à deposição de complexos imunes e à ativação do complemento, resultando em hiper reatividade nas vias aéreas e pneumonia. A análise de cortes de pulmão, postmortem, de crianças vacinadas que apresentaram a doença exacerbada, permitiu a detecção de evidências de ativação do complemento (Polack et al., 2002). Estas observações sugerem que os anticorpos não neutralizantes potenciam a captura e a replicação do vírus em monócitos, que são reconhecidos como permissivos à replicação de HRSV (Krilov et al., 1989)

Apesar deste precedente negativo com a vacina inativada envolvendo a proteína $G$, muitos grupos relataram o uso de peptídeos sintéticos derivados dela como eficazes imunógenos, induzindo tanto imunidade em mucosa quanto sistêmica (Belanger et al., 2000). Um dado comum que aparece nesses trabalhos é de que a resposta de hiper-reatividade após desafio com o HRSV está bastante diminuída (Bastien et al., 1999; Dagouassat et al., 2001; Godefroy et al., 2003). Também foi sugerido que a resposta imune contra $G$ não é a única base para a doença exacerbada da vacina (Johnson et al., 2004a; 2004 b). Assim, a injeção de plasmídios codificando tanto a forma de membrana quanto a secretada da proteína $\mathrm{G}$ induziu uma imunidade Th1/Th2 balanceada sem a inflamação pulmonar atípica após desafio com HRSV em camundongos e ratos (Andersson et al., 2000; Li et al., 2000), sugerindo que a proteína $\mathrm{G}$ pode conferir proteção sem induzir patologia pulmonar exacerbada dependendo do veiculo e/ou método de entrega do antígeno. Seguindo essa lógica, foi demonstrado que a 
vacinação intranasal com um vetor adenoviral expressando o fragmento da proteína $\mathrm{G}$ dos aa 130 a 230 com múltiplas cópias em tandem $(\mathrm{rAd} / 3 \mathrm{xG})$, produziu uma imunidade protetora de longa duração sem sensibilizar as células TCD4+ patológicas nem provocar a doença exacerbada após desafio com HRSV em camundongos Balb/c (Yu et al., 2008).

Acredita-se que uma cura efetiva de HRSV precise da indução de imunidade Th1, envolvendo a ativação de células T citotóxicas secretoras de IFN- $\gamma$. Em adultos, dados apontam que os LTC de memória da maioria dos indivíduos estudados reconhecem a proteína N. As proteínas SH, F, M, M2-1 e NS2 também são reconhecidas em alguns indivíduos, e não existe reconhecimento das proteínas G, P ou NS1 por células TCD8+ humanas (Cherrie et al., 1992).

Em camundongos $C 57 B L / 6$, foram identificados epítopos de células TCD8+ restritos pelo H- $2 \mathrm{D}^{\mathrm{b}}$ na proteína de matriz $\mathrm{M}_{187-195}$ (Rutigliano et al., 2005), bem como nas proteínas F, G e N (Lukens et al., 2006). Foram encontrados três determinantes antigênicos de células T CD8+ principais em camundongos Balb/c H-2 ${ }^{\mathrm{d}}$. A proteína M2-1 (segunda proteína da matriz) contém um epítopo imunodominante M2 82-90, contra o qual respondem de 30 a $50 \%$ das células T CD8+ pulmonares no pico da resposta (Kulkarni et al., 1995; Chang et al., 2002), além de outro sub dominante, M2 127-135 (Lee et al., 2006). Na proteína F também foi encontrado um epítopo sub dominante entre os aa 85 e 93 (Chang et al., 2001). Todos os epítopos são restritos pelo alelo $\mathrm{H}-2 \mathrm{~K}^{\mathrm{d}}$. Algumas evidências indicam que a resposta citotóxica é importante na redução da patologia de HRSV. Células T CD8+ associadas com a imunidade frente ao HRSV em humanos são detectadas no sangue de adultos previamente infectados, existindo uma relação entre a resposta de LTC e os sintomas clínicos reduzidos (Isaacs, 1991). No modelo animal de camundongos as células TCD8+ também mediam a resistência

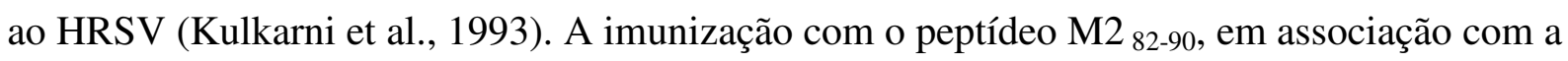
toxina LT (toxina termolábil de Escherichia coli), gerou uma resposta de mucosa de LTC capaz de acelerar a redução da carga viral (Simmons et al., 2001). Células T CD8+ específicas para o peptídeo M2 ${ }_{82-90}$ reduzem a resposta Th2 induzida pela imunização com rVV-G e desafio com HRSV, independente de IFN- $\gamma$ (Simmons et al., 2001). A imunização com FIHRSV não induz uma resposta de células T CD8+ HRSV específica mensurável. No entanto, o estabelecimento de uma resposta de células T CD8+ HRSV específica de memória e potente, antes da imunização com FI-RSV, anula a eosinofilia pulmonar após desafio com o vírus selvagem (Olson e Varga, 2007). Estas observações sugerem que a secreção de IFN- $\gamma$ inibe a secreção de citocinas Th2 e a eosinofilia pulmonar, sugerindo que o balanço da 
resposta de células T determina o resultado da infecção por HRSV (Taylor, 2007). Nesse sentido, vírus sendai recombinante expressando a proteína $\mathrm{F}$ de $\mathrm{HRSV}$ (rSeV F) induziu resposta protetora de anticorpos neutralizantes e de LTC específica para a proteína F, que contem apenas um epítopo de LTC sub dominante. A resposta de LTC protetora foi observada inclusive em camundongos deficientes na produção de anticorpos (Voges et al., 2007).

\subsection{Papel da resposta imune na patogênese da infecção pelo HRSV}

O HRSV se replica, primeiramente, na camada superficial do epitélio respiratório e induz bronquiolite e pneumonia (Aherne et al., 1970; Neilson e Yunis, 1990). A patologia de HRSV em crianças pequenas é caracterizada pela proliferação, necrose e descamação das células epiteliais ciliadas acompanhadas de uma acumulação peribronquiolar de linfócitos e um exudato bronquial composto de muco, células epiteliais descamadas, neutrófilos, linfócitos e macrófagos (Bryson et al., 1983; Thomas et al., 1984; Viuff et al., 1996). O vírus também se replica em células ciliadas do tipo II e induz o engrossamento da parede alveolar com infiltração de macrófagos e neutrófilos. Acreditava-se que a citopatologia mediada diretamente pelo vírus fosse um componente importante da patogênese da infecção com HRSV. Porém, após infecção de células epiteliais humanas, ciliadas e diferenciadas das vias aéreas, com HRSV, não se observa citopatologia (ou é muito pouca) in vitro (Zhang et al., 2002). Isto sugere que a resposta do hospedeiro contra o vírus tem um papel fundamental na patogênese pelo HRSV.

A infecção por HRSV em indivíduos imunosuprimidos também pode provocar uma sintomatologia severa, portanto a resposta imune adaptativa não deve ser um componente fundamental da doença em humanos. A resposta inflamatória iniciada pela infecção viral de células epiteliais pode ser o mediador principal da patologia de HRSV, e os granulócitos recrutados às vias aéreas infectadas podem ser os responsáveis pela destruição das células infectadas. Diferente do que acontece em humanos, a doença e a patologia pulmonar no modelo de infecção por HRSV em camundongo são mediadas, predominantemente, por resposta de células T adaptativas (Graham et al., 1991). Embora este modelo animal tenha limitações, ele tem sido útil no estudo dos tipos de resposta imune que podem contribuir para a patogênese da infecção pelo HRSV. 


\subsection{Controle do HRSV}

Atualmente não existe vacina contra a infecção pelo HRSV. A primeira tentativa de se obter uma vacina foi feita com vírus inativado por formalina nos anos 60 (FI-HRSV). Quando esta seguiu para os testes clínicos em humanos, notou-se que, apesar de induzirem uma forte resposta imune, ela não era protetora (Kim et al., 1969). Além disso, quando os indivíduos imunizados entraram em contato com o HRSV selvagem tiveram uma manifestação muito mais severa da doença provocada pelo vírus, do que pessoas não vacinadas (Openshaw et al., 2001).

Há um grupo de risco bem definido para o desenvolvimento de quadros graves na infecção por HRSV: bebês prematuros; crianças com displasia broncopulmonar, doença cardíaca congênita, ou fibrose cística; pacientes imunodeprimidos; e idosos (Simoes, 1999). Os bebês em risco podem ser protegidos mensalmente por meio de injeção intramuscular de um anticorpo comercialmente disponível (Palivizumab, Synagis ${ }^{\circledR}$ ), administrado durante as epidemias sazonais (American Academy of Pediatrics, 2003). Contudo, esse tratamento é muito caro e inconveniente para uso generalizado. Também não se conta com uma terapia antiviral, clinicamente efetiva, contra o HRSV. O análogo de nucleosídeo ribavirina é efetivo em cultura de células e em animais experimentais, porém tem decepcionado na prática clínica (American Academy of Pediatrics, 1996). Por outro lado, o controle de HRSV por um agente antiviral impõe desafios: é uma infecção aguda rápida e quando a doença é reconhecida pode ser tarde demais para controlá-la apenas com terapia antiviral. A administração tópica de anticorpos neutralizantes, tem sido empregada como uma terapia alternativa, contudo, não tem sido efetiva, provavelmente devido às mesmas dificuldades expostas para o uso dos antivirais (Rodriguez et al., 1997).

Assim, existe a necessidade de uma vacina contra o HRSV, sendo necessárias, provavelmente, dois tipos de vacinas. A necessidade primária é uma vacina pediátrica para ser administrada, preferivelmente, nas primeiras semanas de vida. A outra, seria uma vacina para indivíduos que já foram infectados pelo vírus e se encontram em risco de desenvolver doença severa pelo HRSV. Essas exigências só vêm reforçar o fato de que o desenvolvimento de vacinas visando a prevenção e o tratamento da infecção pelo HRSV tem sido dificultado por diversos fatores. Eles estão relacionados com a necessidade de imunizar nas primeiras semanas de vida, ou são fatores inerentes à infecção pelo HRSV, ou à resposta do hospedeiro contra o vírus. Dentre eles, temos a imaturidade do sistema imune da população infantil alvo (Crowe, 1999); o efeito imunossupressor dos anticorpos maternais durante os primeiros meses 
de vida (Crowe et al., 2001); a natureza altamente infecciosa do vírus (Collins et al., 2001); a capacidade dele para infectar bem cedo no ciclo de vida (Stein et al., 1999), apesar da presença de anticorpos maternais; o crescimento ineficiente in vitro e a instabilidade física dos vírus; a falta de modelos animais permissivos apropriados (Collins et al., 2001); a presença de dois grupos antigênicos (Mufson et al., 1985); o fato de que não existe imunidade vitalícia (CDC, 2004; Falsey et al., 2005); os eventos adversos, acarretados pela primeira vacina testada em que o vírus foi inativado com formalina (Kim et al., 1969); e sua associação com doença respiratória de hiper reatividade (Schwarze et al., 1997).

A estratégia de vacina contra HRSV mais favorável para uma população soronegativa, deve consistir de componentes que não deixem seqüelas imunopatológicas e, ao mesmo tempo, atinjam uma resposta imune protetora balanceada mediada por células T CD8+ e CD4+ Th1. Pouco tem sido estudado com respeito à resposta imune contra a polimerase do vírus, proteína estrutural grande e altamente conservada. O desenvolvimento de programas de predição permite realizar análise de sequiências peptídicas procurando epítopos que possam ser apresentados tanto por células $\mathrm{T}$ CD8+ (restritos pelo complexo maior de histocompatibilidade do tipo I, MHC-I) quanto por células TCD4+ (restritos pelo MHC-II). Isso minimiza o número de experimentos a serem realizados porque possibilita a busca sistemática de epítopos em proteínas grandes (De Groot et al., 2001).

Neste trabalho foram desenvolvidas duas estratégias vacinais. Na primeira utilizamos a proteína L como imunógeno e realizamos a identificação de epítopos (prediptopes) de células TCD8+ utilizando programas de predição. Os peptídeos selecionados foram sintetizados e avaliados em ensaios celulares, testando sua imunogenicidade pela capacidade de induzir a produção de IFN- $\gamma$. A partir desses resultados poderemos compor um gene múlti-epítopo com os melhores epítopos caracterizados até o momento, inseri-lo em vetor de expressão eucarioto, e testá-lo como vacina de DNA. A segunda estratégia baseia-se numa sequiência do ectodomínio da proteína G (comentada no item 1.6.2.2 acima): um peptídeo de 41 aminoácidos (aa) (164 a 204) (HFEVFNFVPCSICSNNPTCWAICGRGP NGKPGKKTTTKPTK) com mutações introduzidas na seqüência aminoacídica (glicinas indicadas em azul), que denominamos GM. Este peptídeo possui epítopos interessantes para obter uma resposta imune protetora sem a indução de resposta inflamatória (Tebbey et al., 1998). Para tanto, é proposta sua utilização como imunógeno em vacina de DNA, fusionado à CTB, um potente adjuvante (Arêas et al., 2004), e à sequiência sinal do TpA, o que favorecerá a sua secreção (Yu et al., 2008). Esta estratégia foi complementada pela obtenção e 
purificação dessas proteínas quiméricas expressas em bactérias, bem como em testar sua capacidade imunogênica. 


\section{OBJETIVOS}

\subsection{Objetivos gerais:}

Avaliar a resposta imune de LTC contra a proteína L do vírus HRSV no modelo animal de camundongos Balb/c;

Construir ferramentas que possibilitem obter uma resposta imune protetora contra o HRSV no modelo animal de camundongos Balb/c, direcionada ao peptídeo GM da glicoproteína G.

\subsection{Objetivos específicos:}

Identificação de epítopos de células TCD8+ na proteína L do vírus HRSV por predição;

Avaliação da resposta imune celular contra os peptídeos correspondentes a esses epítopos de células TCD8+ da proteína L;

$>$ Avaliar a resposta imune celular contra os peptídeos correspondentes aos epítopos de células TCD8+ da proteína L no contexto da infecção viral;

> Construção de vetores plasmidiais baseados no peptídeo GM mutado;

$>$ Testar a expressão das proteínas codificadas pelos genes clonados nos plasmídios pTGM, pTCTB e pTGMCTB em células de mamíferos;

$>$ Testar a resposta imune contra as proteínas codificadas pelos genes clonados nos vetores de expressão eucariótica, plasmídios pTGM e pTGMCTB, usando como controle pT e pTCTB;

$>$ Testar a capacidade protetora da imunização com os vetores de expressão eucariótica construídos (pTGM e pTGMCTB) frente ao desafio com HRSV A2;

$>$ Expressar e purificar as proteínas recombinantes baseadas no peptídeo GM mutado, a partir de vetores de expressão bacterianos;

Testar a imunogenicidade das proteínas purificadas e a atividade neutralizante dos anticorpos anti-GM obtidos, contra o HRSV em cultura celular;

Testar a capacidade protetora da imunização com as proteínas purificadas, frente ao desafio com HRSV A2. 


\section{MATERIAL E MÉTODOS}

$\mathrm{Na}$ metodologia descrita a seguir mencionaremos técnicas convencionais baseadas em Sambrook et al., 1989 (para Biologia Molecular) e Harlow e Lane, 1988 (para Imunologia).

\subsection{Metodología Geral}

\subsubsection{Linhagens celulares bacterianas}

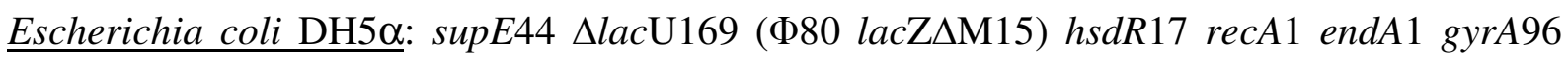
thi-1 relA1

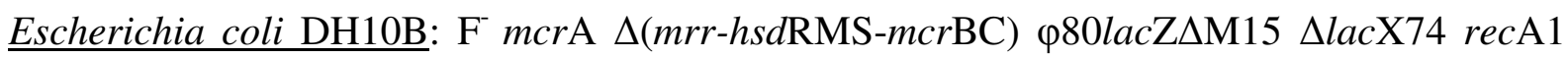
endA1 araD1394(ara, leu)7697 galU galK $\lambda$ - rpsL nupG (Invitrogen ${ }^{\mathrm{TM}}$, Carlsbad, Califórnia, USA)

$\underline{\text { BL21(DE3)pLysS: }} \mathrm{F}^{-}$omp $\mathrm{T} h s d \mathrm{~S}_{\mathrm{B}}\left(\mathrm{r}_{\mathrm{B}}{ }^{-}, \mathrm{m}_{\mathrm{B}}{ }^{-}\right)$gal dcm $\lambda(\mathrm{DE} 3)$ [pLysS Cam ${ }^{\mathrm{r}}$ ] (Novagen $^{\mathrm{TM}}$, Darmstadt, Alemanha)

\subsubsection{Linhagens celulares eucariotas}

Hep-2: Linhagem de células oriunda de carcinoma de laringe humano (Moore et al., 1955). Esta linhagem celular é usada na replicação do vírus sincicial respiratório. Obtida junto ao American Type Culture Collection (ATCC), EUA.

HEK-293T: Linhagem de células altamente transfectáveis derivada de HEK 293 (oriunda de rim de embrião humano) que expressam estável e constitutivamente o antígeno T de SV40 (DuBridge et al., 1987). A linhagen celular foi obtida junto ao ATCC, EUA.

As duas linhagens celulares foram subcultivadas rotineiramente em meio MEM (Cultilab, Campinas, SP, Brasil) suplementado com 10\% de soro fetal bovino (SFB), 100 $\mu \mathrm{g} / \mathrm{mL}$ de gentamicina e $8 \mu \mathrm{g} / \mathrm{mL}$ de Tylosina. As células foram incubadas em estufa a $37^{\circ} \mathrm{C}$ em atmosfera de $5 \%$ de $\mathrm{CO}_{2}$. 


\subsubsection{Meios de cultura bacteriana}

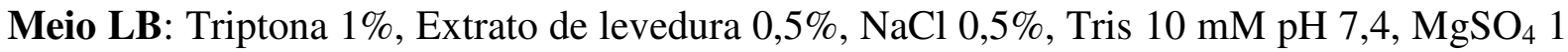
mM. O meio foi esterilizado mediante autoclavação por 20 minutos (min) a $120^{\circ} \mathrm{C}$.

Meio SOC: Triptona $2 \%$, Extrato de levedura 0,5\%, $\mathrm{NaCl} 10 \mathrm{mM}, \mathrm{KCl} 2,5 \mathrm{mM}, \mathrm{MgCl}_{2} 10$ $\mathrm{mM}, \mathrm{MgSO}_{4} 10 \mathrm{mM}$, Glicose $20 \mathrm{mM}$. O meio foi esterilizado mediante autoclavação por 20 $\min$ a $121^{\circ} \mathrm{C}$.

Meio LB antibiótico: Meio LB acrescido do antibiótico ampicilina ou kanamicina a uma concentração final de $50 \mu \mathrm{g} / \mathrm{mL}$.

Meio LB/Ágar/antibiótico: Preparação de meio LB na qual foi acrescido 1,5\% de ágar bacteriológico antes da autoclavagem e adicionado antibiótico ampicilina ou kanamicina, a uma concentração final de $50 \mu \mathrm{g} / \mathrm{mL}$. O meio foi solidificado em placas de cultura bacteriana.

\subsubsection{Plasmídios}

\subsubsection{Vetores de expressão bacterianos}

Figura 2- Vetor pAE-ctxB.

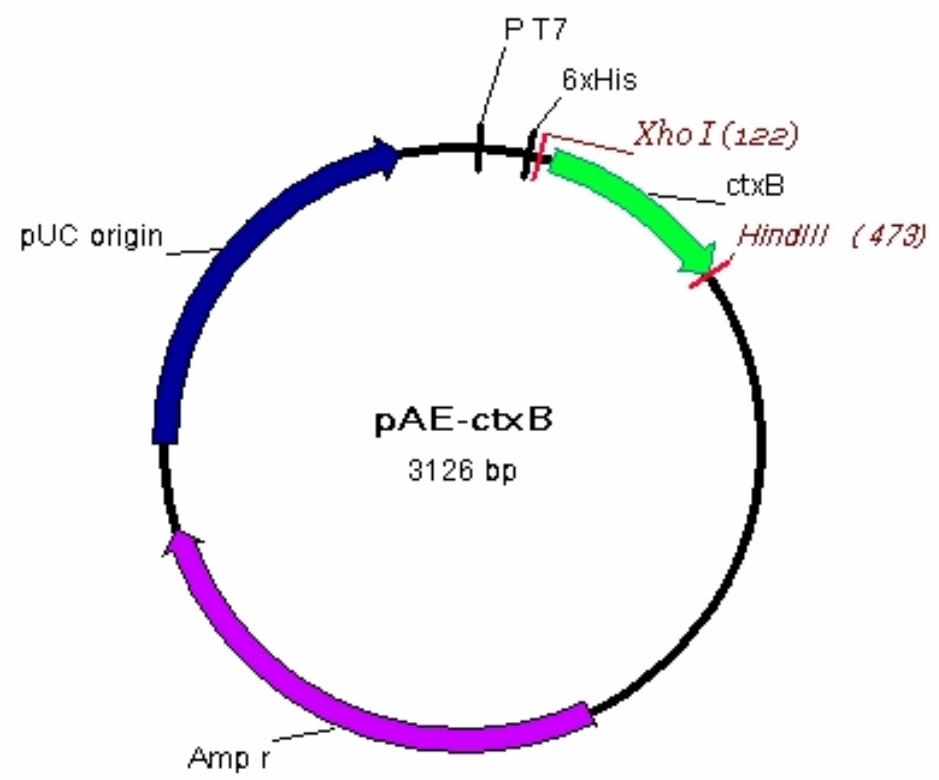

Vetor utilizado para a expressão da proteína CTB. O plasmídio pAE possui um gene sintético que codifica a sequiência do gene da subunidade B da toxina colérica (ctxB) com uma cauda de 6 histidinas no N- terminal (Arêas et al., 2002).

Fonte: Medina-Armenteros (2012) 
Figura 3- Vetor pAE-ctxB-GM.

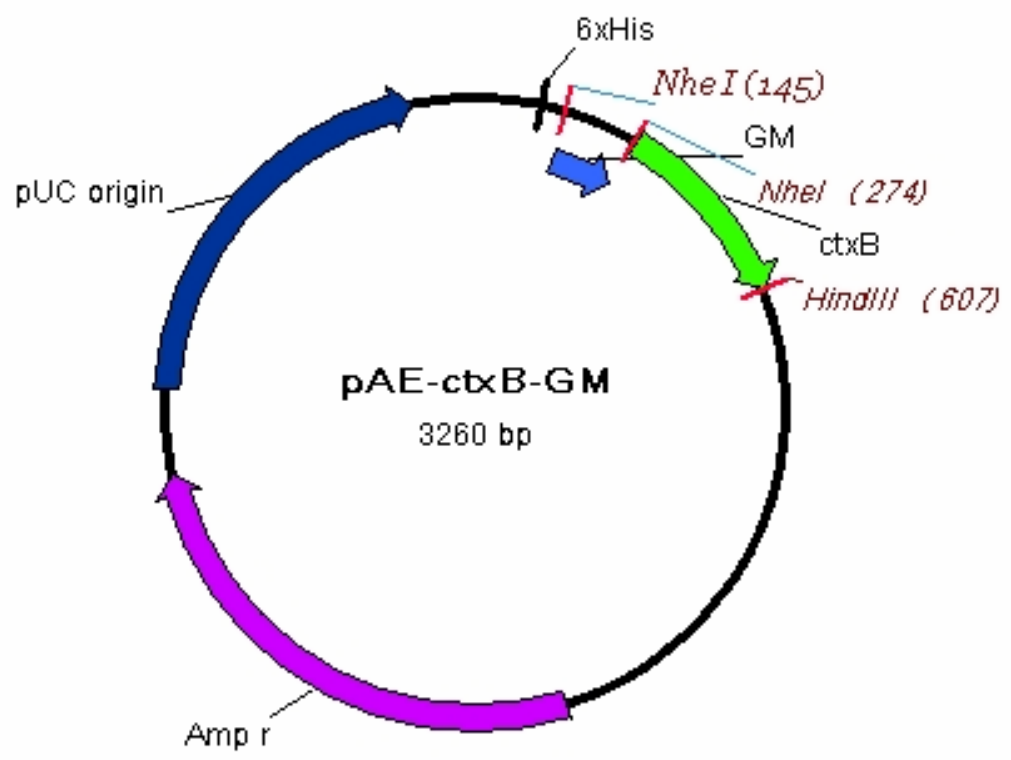

Vetor utilizado para a expressão da proteína de fusão GMCTB o qual foi produzido anteriormente no laboratório. Este plasmídeo consiste no vetor pAE-ctxB (Arêas et al., 2002) que contem clonado o gene que codifica para o peptídeo GM no extremo amino terminal (N-terminal) do gene ctxB. O peptídeo GM abrange os resíduos 164-204 da glicoproteína G do HRSV com mutações nas posições 187,189 e 192.

Fonte: Medina-Armenteros (2012)

\subsubsection{Vetores de expressão em eucariotos}

Figura 4- Vetor pcDNA3.

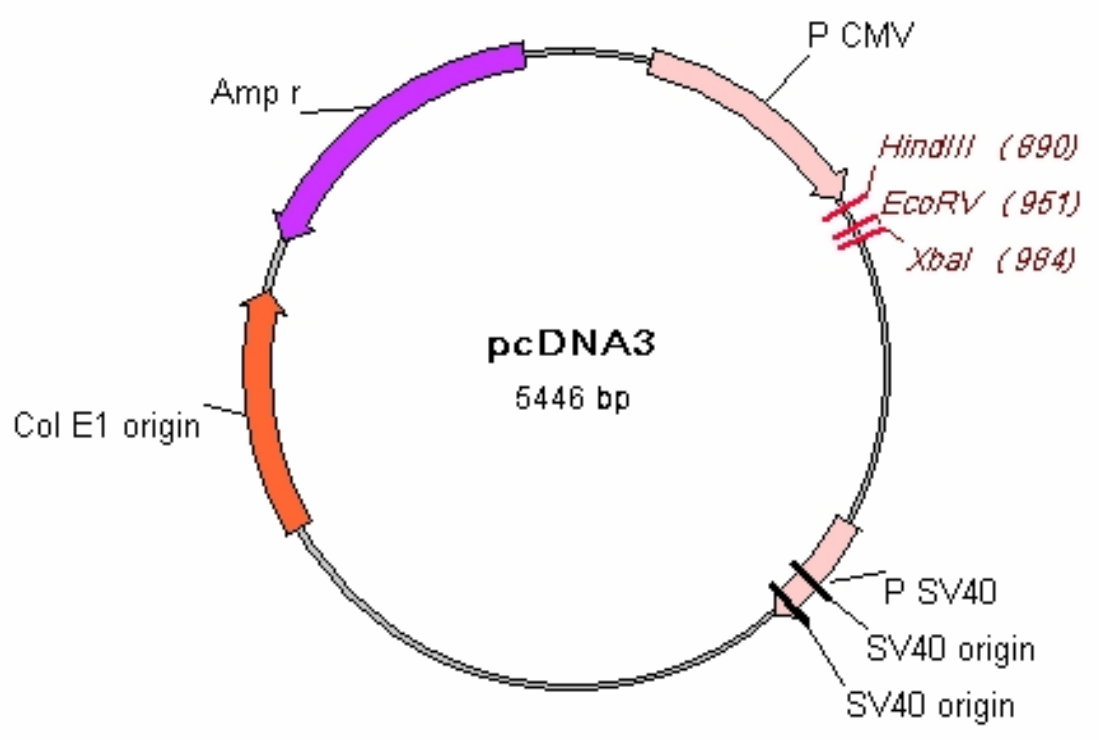

Vetor utilizado para a expressão de genes em células de mamíferos (Invitrogen ${ }^{\mathrm{TM}}$ ).

Fonte: Medina-Armenteros (2012) 
Figura 5- Vetor pT.

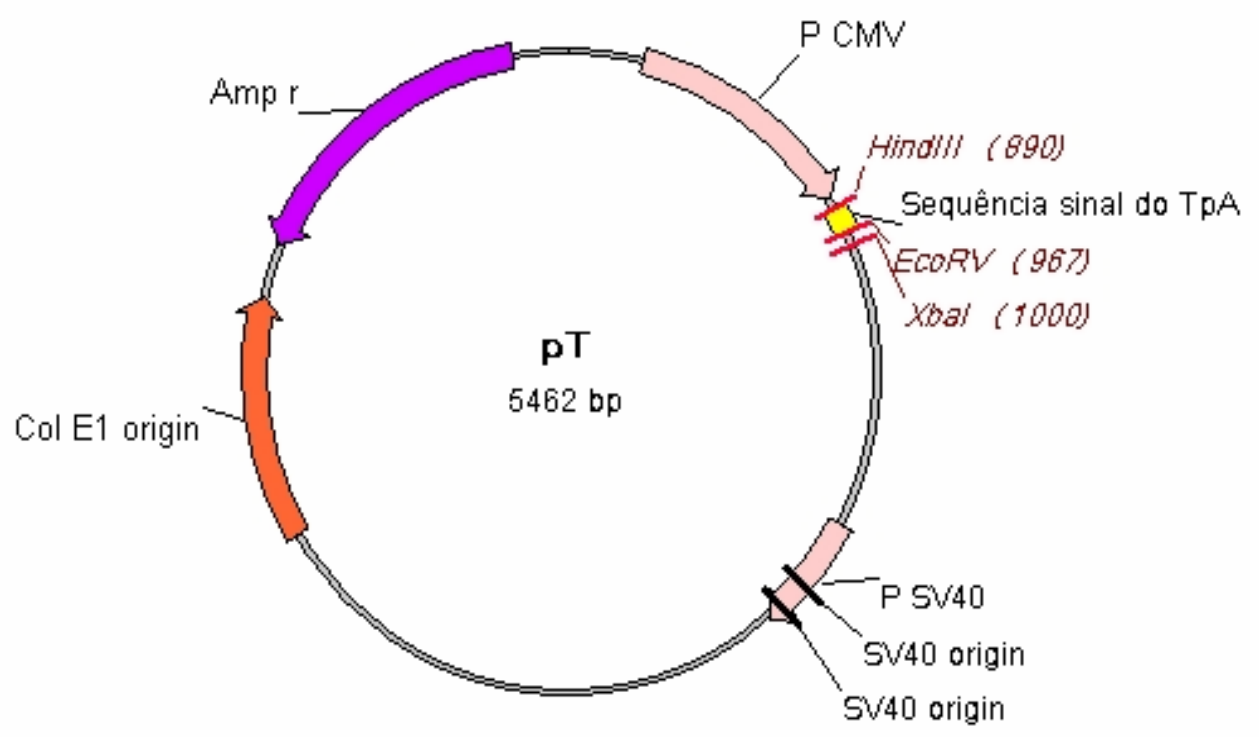

Plasmídio pcDNA3 em que foi inserida a seqüência sinal do ativador de plasminogênio tecidual (TpA) de $69 \mathrm{pb}$ clonada entre os sítios Hind III e Eco RV.

Fonte: Medina-Armenteros (2012)

Figura 6- Vetor pTGM.

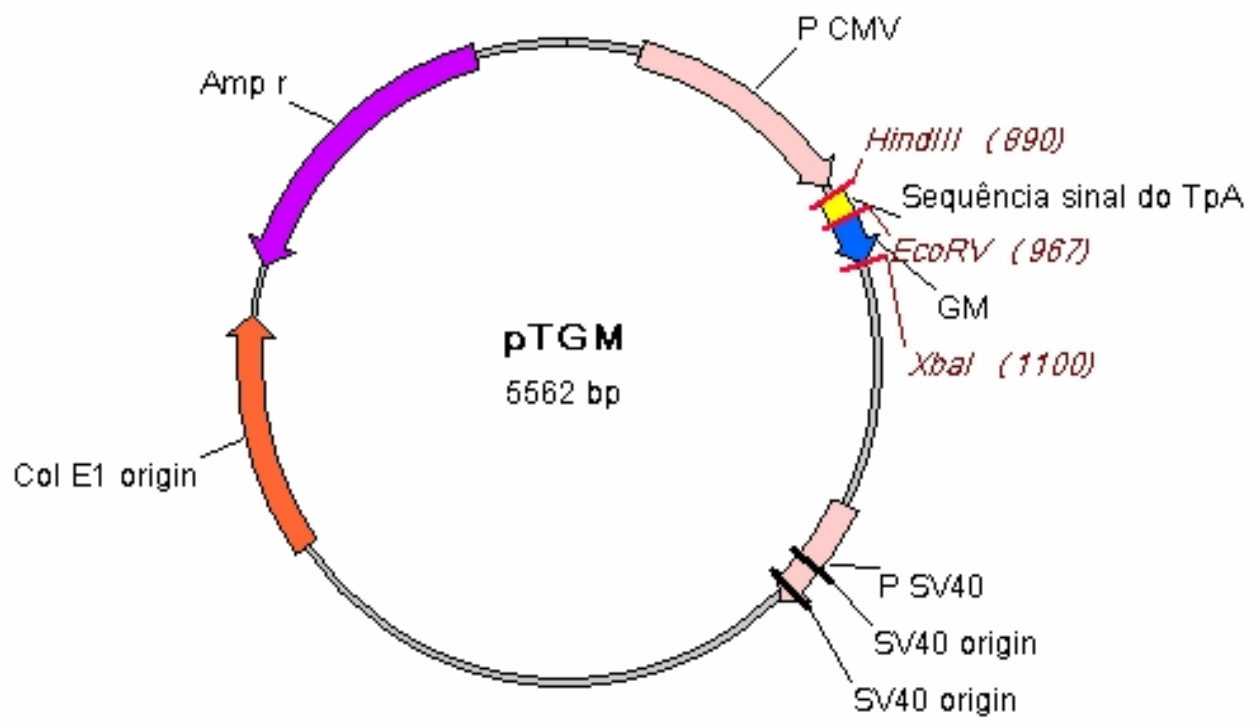

Plasmídio pT em que foi inserida a seqüência de GM (129pb) no C- terminal do TpA entre os sítios EcoRV e XbaI.

Fonte: Medina-Armenteros (2012) 
Figura 7- Vetor pTCTB.

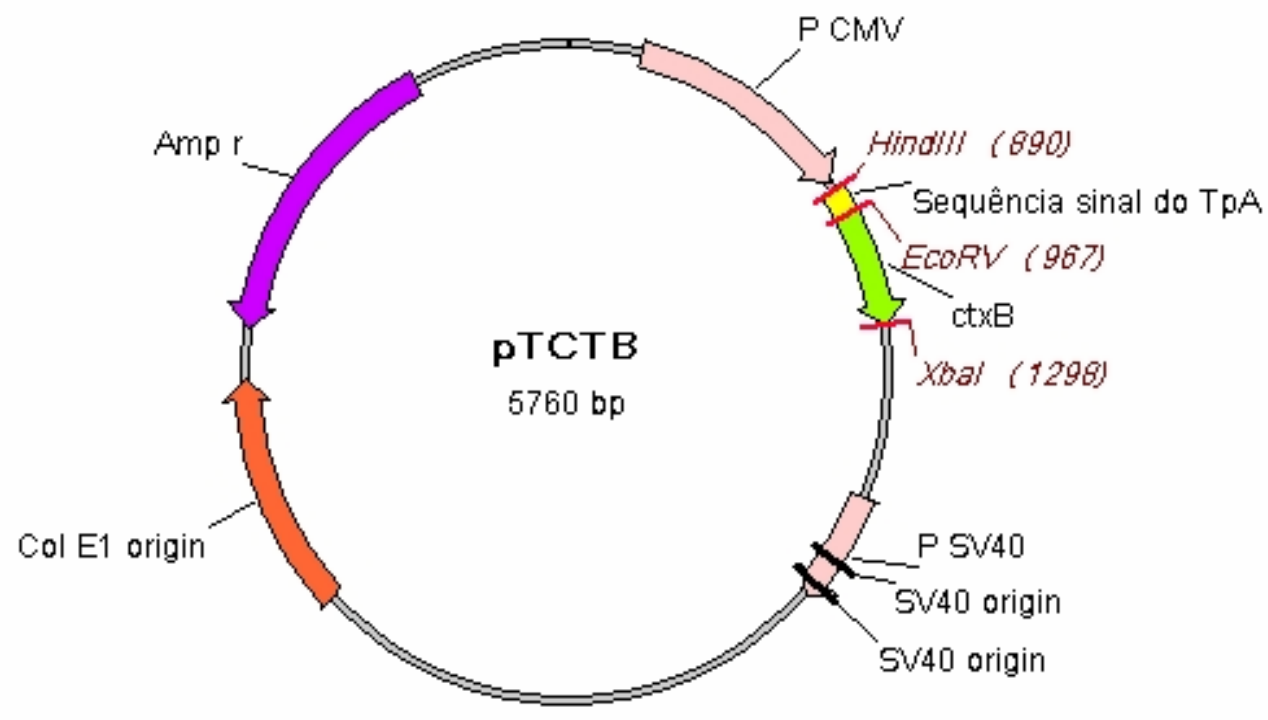

Plasmídio pT em que foi inserida a sequiência da subunidade B da toxina colérica (Arêas et al., 2002) de 327 pb, no C- terminal do TpA, entre os sítios EcoRV e XbaI.

Fonte: Medina-Armenteros (2012)

Figura 8- Vetor pTGMCTB.

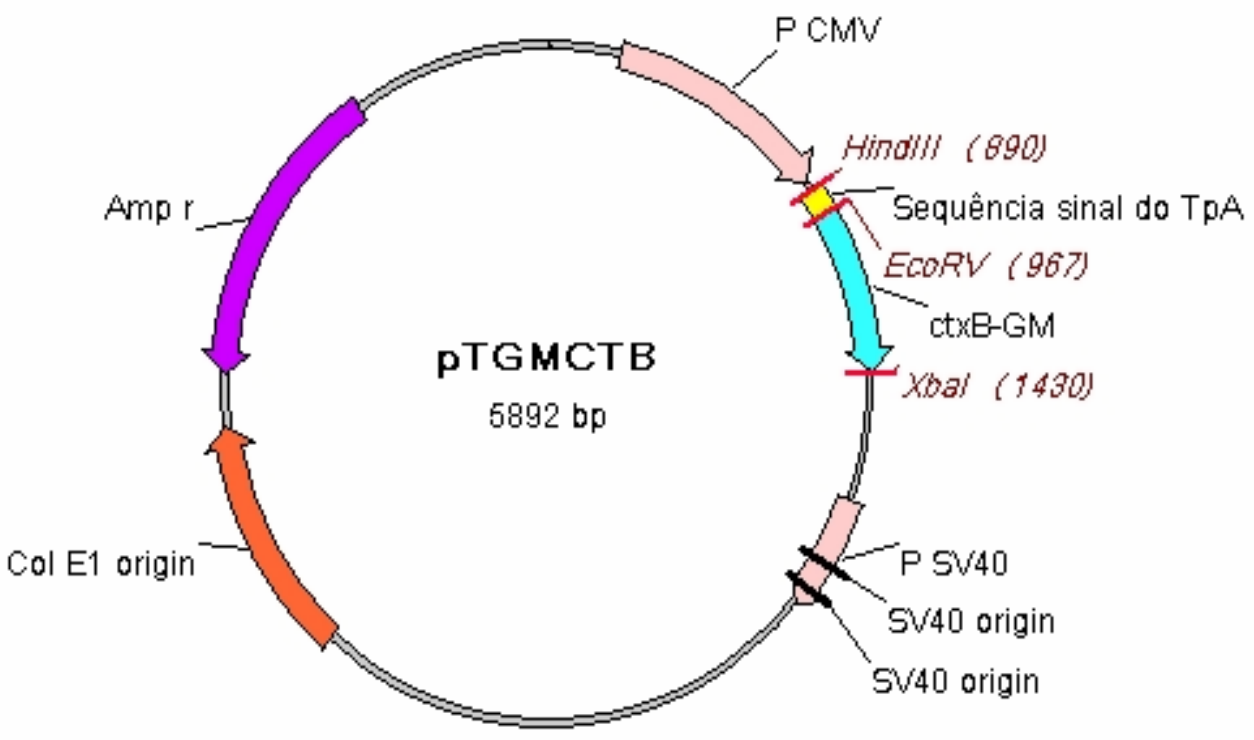

Plasmídio pT em que foi inserida a sequiência do gene que codifica para a proteína de fusão GMCTB (peptídeo GM com a subunidade B da toxina colérica, $459 \mathrm{pb}$ ), no C- terminal do TpA, entre os sítios EcoRV e XbaI.

Fonte: Medina-Armenteros (2012) 


\subsubsection{Oligonucleotídeos}

\section{Oligonucleotídeos para clonagem}

O desenho destes oligonucleotídeos foi baseado nas seqüências disponíveis no GenBank para a proteína G do HRSV A2 protótipo e da CTB (Arêas et al., 2002). Os oligonucleotídeos específicos para clonagem contêm as seqüências de corte das enzimas de restrição $E c o R V$ (azul) e XbaI (verde) para clonar no plasmídio pT, vetor construído a partir de pcDNA3; além do códon de iniciação ATG (foward) e de parada TAA (reverse). Também foram trocados nucleotídeos (vermelho) para otimizar a expressão dos genes GM, ctxB e ctxB-GM em células animais usando parâmetros de otimização da base de dados HEG-DB (Highly Expressed Genes Database). Para o desenho das seqüências dos oligonucleotídeos, foram utilizados os programas contidos no "Lasergene sequence analysis software" da DNAStar Inc.

\section{GM}

Forward: TPGF 5 - CGA TGA TAT CAT GCA CTT CGA GGT GTT CAA CT - 3 Reverse: TPGR 5 - CGA TTC TAG ATT ACT TGG TGG GCT TGG TGG TG - 3`

O oligonucleotídeo forward foi desenhado para anelar entre os nucleotídeos 150 e 171 do vetor pAE-ctxB-GM, e o reverse, para anelar entre os nucleotídeos 251 e 272.

\section{ctxB}

Forward: TPCTF 5 - CGA TGA TAT CAT GAC CCC CCA GAA CAT CAC CG - 3

Reverse: TPCTR 5 - CGA TTC TAG ATTAGCTCTCCCGGGTGTTGGCC - 3

O oligonucleotídeo foward foi desenhado para anelar entre os nucleotídeos 282 e 303 do vetor pAE-ctxB-GM e, o reverse, para anelar entre os nucleotídeos 584 e 605 . Essas posições correspondem à seqüência madura da proteína CTB no gene ctxB, acrescida de 4 aa no Cterminal (T-R-E-S) (Arêas et al., 2002).

\section{ctxB-GM}

Forward: TPGF 5 - CGA TGA TAT CAT GCA CTT CGA GGT GTT CAA CT - 3

Reverse: TPCTR 5 - CGA TTC TAG ATT AGC TCT CCC GGG TGT TGG CC - 3` 


\section{Oligonucleotídeos para pcDNA3}

Oligonucleotídeos que amplificam seqüências do vetor pcDNA3; SF13 anela entre os nucleotídeos 770 e 785 e 90pbFLAGR, entre 1075 e 1088.

S13 F: 5'- GCAAATGGGCGGTAGG-3'

90bp FLAGR: 5’' CACGGGGGAGGGGC-3'

\section{Oligonucleotídeos para o gene $\mathbf{N}$}

Oligonucleotídeos desenhados para anelar entre os nucleotídeos 747 e 771 (NF) e 915 e 941 (NR) do gene $\mathrm{N}$ do HRSV.

NF: 5' -AGG ATT GTT TAT GAA TGC CTA TGG T -3’

NR: 5 -GCT TTT GGG TTG TTC AAT ATA TGG TAG-3’

\subsubsection{Preparo de células eletro competentes}

Este protocolo foi usado como padrão para as diferentes linhagens de Escherichia coli (E. coli) utilizadas no projeto.

Bactérias E. coli foram inoculadas em $10 \mathrm{~mL}$ de meio $\mathrm{LB}$ e incubadas a $37{ }^{0} \mathrm{C}$ durante 16 horas (h) sob agitação a 200 revoluções por minuto (rpm). Dessa cultura em fase estacionária, foram inoculados $5 \mathrm{~mL}$ em $500 \mathrm{~mL}$ de meio LB (1/100 do volume), e incubadas a $37{ }^{0} \mathrm{C}$ sob agitação a $200 \mathrm{rpm}$. Quando o crescimento atingiu uma $\mathrm{DO}_{600 \mathrm{~nm}}$ de aproximadamente 0,6 , a cultura foi transferida para tubos de centrífuga e mantida no gelo por $30 \mathrm{~min}$. Finalizado este período, a suspensão de células foi centrifugada a $4{ }^{0} \mathrm{C}$ por 15 min a $2.500 \mathrm{x} \mathrm{g}$, sendo o sobrenadante removido e o sedimento ressuspendido em $500 \mathrm{~mL}$ de água Milli-Q estéril gelada, tomando-se cuidado para não lisar as células. A suspensão foi centrifugada novamente a $2.500 \mathrm{x}$ g por $15 \mathrm{~min}$ a $4{ }^{0} \mathrm{C}$, e o sedimento foi ressuspendido em $250 \mathrm{~mL}$ de água Milli-Q estéril gelada.

Após centrifugação a 2.500 x g por 15 min a $4{ }^{0} \mathrm{C}$, o sedimento foi ressuspendido em 10 $\mathrm{mL}$ de solução de glicerol $10 \%$ gelada preparada com água ultrapura. Em seguida, procedeuse uma nova centrifugação a 2.500 x g por 15 min a $4{ }^{0} \mathrm{C}$ e o sedimento foi ressuspendido em um volume de $1,5 \mathrm{~mL}$ da mesma solução de glicerol 10\%. A suspensão de células foi dividida em alíquotas de $50 \mu \mathrm{L}$, congelada em nitrogênio líquido e estocada a $-70{ }^{0} \mathrm{C}$. Durante a preparação, as células foram mantidas constantemente em gelo. 


\subsubsection{Eletro transformação de bactérias competentes}

Uma alíquota de bactérias eletro competentes foi descongelada e mantida em gelo juntamente com as cubetas para eletroporação e o DNA com o qual se pretende transformar. Ao tubo de bactérias foi adicionado $1 \mu \mathrm{L}$ do DNA e se incubou no gelo por 60 segundos (seg). O aparelho Gene pulser (Bio Rad, Hercules, California, USA) foi ajustado para $25 \mu \mathrm{F}$, $200 \Omega$ e $2,5 \mathrm{KV}$. Foram utilizadas cubetas de $0,2 \mathrm{~cm}$ de largura (Bio Rad). A mistura foi transferida para a cubeta de eletroporação e homogeneizada. Em seguida, a cubeta foi conectada ao aparelho de modo que ficasse localizada entre os dois eletrodos, aplicou-se o pulso registrando o tempo de exposição. Imediatamente após o pulso, foi adicionado $1 \mathrm{~mL}$ de meio SOC e as células foram ressuspendidas com pipeta Pasteur. A suspensão foi transferida para um tubo novo e incubada a $37{ }^{0} \mathrm{C}$ com agitação de $200 \mathrm{rpm}$ durante $1 \mathrm{~h}$. Terminada a incubação, $100 \mu \mathrm{L}$ das células foram plaqueados em meio LB/Agar/antibiótico e incubadas por 16 hs a $37{ }^{0} \mathrm{C}$.

\subsubsection{Extração de plasmídio em pequena escala (Mini-preparação)}

O isolamento de plasmídios a partir de bactérias se deu pelo protocolo de lise alcalina (Birnboim e Doly, 1979). Partiu-se de colônias bacterianas crescidas em placas de meio LB/Agar/antibiótico. Colônias isoladas foram inoculadas individualmente em $3 \mathrm{~mL}$ de meio LB antibiótico e incubadas por 16 hs a $37{ }^{0} \mathrm{C}$ sob agitação. Após este período, $1,5 \mathrm{~mL}$ da cultura foram centrifugados a $12.000 \mathrm{x} \mathrm{g}$, e o precipitado de células obtido foi ressuspendido em $100 \mu \mathrm{L}$ de solução I (glicose 50 mM, 25 mM Tris-HCl, pH 8,0, EDTA $10 \mathrm{mM}$ ) contendo $4 \mathrm{mg} / \mathrm{mL}$ de lisozima. As células foram incubadas a temperatura ambiente (TA) por $5 \mathrm{~min}$. Em seguida foram adicionados $200 \mu \mathrm{L}$ de solução II (NaOH 0,2 M, SDS 1\%). O tubo foi invertido cuidadosamente 3 vezes e incubado em gelo por $5 \mathrm{~min}$. A seguir, foram adicionados $150 \mu \mathrm{L}$ de solução III (acetato de potássio 3 M, ácido acético glacial 11,5\%, pH 4,8). O tubo foi agitado vigorosamente e incubado no gelo por mais $5 \mathrm{~min}$. Posteriormente o tubo foi centrifugado a 12.000 x g a $4{ }^{0} \mathrm{C}$ por $10 \mathrm{~min}$. O sobrenadante foi coletado e a este foi adicionado igual volume de fenol-clorofórmio (1:1). A solução foi homogeneizada agitandose vigorosamente e em seguida foi centrifugada a $12.000 \mathrm{x}$ g por $5 \mathrm{~min}$ para separar as fases. A fase aquosa resultante (superior) foi coletada e acrescida de 2 volumes de etanol $95 \%$. A 
amostra foi incubada a TA por 2 min, em seguida centrifugada a 12.000 x g por 10 min a TA. O sobrenadante foi desprezado e o precipitado resultante lavado com $500 \mu \mathrm{L}$ de etanol $70 \%$ e centrifugado por mais $5 \mathrm{~min}$ a $12.000 \mathrm{x} \mathrm{g}$. Novamente o sobrenadante foi desprezado e o precipitado deixado a TA para secar. Quando seco, o DNA plasmidial foi ressuspendido em $30 \mu \mathrm{L}$ de tampão TE (Tris-HCl 10 mM, pH 8,0, EDTA $1 \mathrm{mM}$ ) contendo $20 \mu \mathrm{g} / \mathrm{mL}$ de RNase e incubado por $15 \min$ a $37{ }^{0} \mathrm{C}$.

\subsubsection{Purificação de DNA plasmidial em grande escala}

De acordo com o protocolo seguido (Sambrook et al., 1989), a cultura de 1L foi separada em garrafas de $400 \mathrm{~mL}$ e centrifugadas a $6.000 \mathrm{rpm}$ durante $15 \mathrm{~min}$, a $4{ }^{0} \mathrm{C}$. Após o descarte do sobrenadante, os precipitados foram ressuspendidos em $30 \mathrm{~mL}$ (volume final) de solução I (50mM glicose, 25mM Tris-HCl e 10mM EDTA), sendo reunidos em um único tubo. Posteriormente, foram adicionados $60 \mathrm{~mL}$ de solução II $(0,2 \mathrm{~N} \mathrm{NaOH}$ e $1 \%$ SDS $)$ e a mistura foi homogeneizada por inversão e incubada em gelo por $10 \mathrm{~min}$. Adicionaram-se 30 mL de solução III (5M KAc, pH 5,2), misturou-se gentilmente e novamente a mistura foi incubada em gelo por $20 \mathrm{~min}$; após este período, foi realizada centrifugação a $6.000 \mathrm{rpm}$ durante $15 \mathrm{~min}$, a $4{ }^{0} \mathrm{C}$. O sobrenadante foi filtrado em gaze para um novo tubo, adicionou-se isopropanol correspondente a $60 \%$ do volume obtido, e a solução foi incubada por $1 \mathrm{~h}$ a TA. A solução foi então centrifugada a $8.000 \mathrm{rpm}$ durante $15 \mathrm{~min}$, a $4{ }^{0} \mathrm{C}$; o sobrenadante foi descartado e o precipitado foi ressuspendido em $5 \mathrm{~mL}$ de TE (10mM Tris- $\mathrm{HCl}$ e $1 \mathrm{mM}$ EDTA, $\mathrm{pH} 8,0)$ e transferido para um tubo de $15 \mathrm{~mL}$.

Adicionou-se $1 \mathrm{~g}$ de $\mathrm{NH}_{4} \mathrm{Ac}$ anidro e a solução foi misturada vigorosamente e incubada em gelo por $20 \mathrm{~min}$. Foi realizada uma centrifugação a $8.000 \mathrm{rpm}$ durante $15 \mathrm{~min}$, a $4{ }^{0} \mathrm{C}$ e o sobrenadante foi transferido para um novo tubo de $50 \mathrm{~mL}$. Adicionou-se $2 \mathrm{X}$ o volume de etanol absoluto e a solução foi misturada vigorosamente e incubada durante 30 min a $-20{ }^{0} \mathrm{C}$. Foi realizada nova centrifugação a $8.000 \mathrm{rpm}$ durante $15 \mathrm{~min}$, a $4{ }^{0} \mathrm{C}$ e o sobrenadante foi descartado. O precipitado resultante foi ressuspendido em $400 \mu \mathrm{L}$ (volume final) de água Milli-Q e transferido para um tubo eppendorf. Adicionou-se $1 \mu \mathrm{L}$ de RNase $(20 \mathrm{mg} / \mathrm{mL})$ e a solução foi incubada durante $15 \mathrm{~min}$, a $37{ }^{0} \mathrm{C}$. Adicionou-se $400 \mu \mathrm{L}$ de tampão para proteinase $\mathrm{K}(2 \mathrm{X} ; 20 \mathrm{mM}$ Tris- $\mathrm{HCl}, 10 \mathrm{mM}$ EDTA e $1 \%$ SDS $), 20 \mu \mathrm{L}$ de proteinase $\mathrm{K}(20$ $\mathrm{mg} / \mathrm{mL}$ ) e a solução foi incubada a $37{ }^{0} \mathrm{C}$ por mais $30 \mathrm{~min}$. $\mathrm{O}$ volume final foi separado em 2 tubos eppendorf, sendo adicionado o mesmo volume de fenol:clorofórmio:álcool isoamílico 
(25:24:1) em cada um e as soluções foram misturadas vigorosamente e centrifugadas a 12.000 rpm durante $5 \mathrm{~min}$, a $4{ }^{0} \mathrm{C}$. A fase aquosa (superior) foi recolhida e transferida para novos tubos eppendorf e seguiram-se três lavagens com igual volume de clorofórmio, centrifugação (12.000 rpm, $15 \mathrm{~min}, 4{ }^{0} \mathrm{C}$ ) e coleta da fase aquosa. Após as lavagens, adicionou-se $10 \%$ do volume KAc 3M, 2X o volume de etanol absoluto e a solução foi misturada vigorosamente e incubada a $-80{ }^{\circ} \mathrm{C}$ por $30 \mathrm{~min}$. Foi realizada uma centrifugação a $12.000 \mathrm{rpm}$ durante $10 \mathrm{~min}$, a $4{ }^{0} \mathrm{C}$, e o sobrenadante foi descartado. O precipitado resultante foi lavado com $500 \mu \mathrm{L}$ de etanol $70 \%$ com posterior centrifugação (12.000 rpm, 5 min, $4{ }^{0} \mathrm{C}$ ), ressuspendido em 100-200 $\mu \mathrm{L}$ de TE, e o DNA estocado a $-20{ }^{0} \mathrm{C}$. Cada amostra teve sua concentração de DNA quantificada por medida de absorbância a 260 e $280 \mathrm{~nm}$ em espectrofotômetro (Nanodrop ${ }^{\circledR}$ ).

\subsubsection{Reação em cadeia da polimerase (PCR)}

As reações de amplificação foram realizadas usando o kit de amplificação Platinum ${ }^{\circledR}$ Pfx DNA Polymerase da Invitrogen ${ }^{\mathrm{TM}}$. Na mistura da reação foram adicionados: $5 \mu \mathrm{L}$ de $P f x$ Amplification Buffer 10X, $1.5 \mu \mathrm{L}$ de dNTP $10 \mathrm{mM}\left(0,3 \mathrm{mM}\right.$ cada), $1 \mu \mathrm{L}$ de $\mathrm{MgSO}_{4} 50 \mathrm{mM}$, $1,5 \mu \mathrm{L}$ de cada oligonucleotídeo $(0,3 \mathrm{mM}$ cada), $10 \mathrm{ng}$ do plasmídio pAE-ctxB-GM, $1 \mathrm{U}$ da enzima DNA polimerase Platinum ${ }^{\circledR} P f x$ DNA e água DEPC (água Milli-Q tratada com dietilpirocarbonato, conforme descrito em Sambrook et al., 1989) até completar um volume de $50 \mu \mathrm{L}$. A reação foi preparada em tubos de $200 \mu \mathrm{L}$ apropriados para o termociclador Mastercycler personal da Eppendorf (Hamburgo, Alemanha). Neste aparelho foi feita incubação inicial de 2 min a $94{ }^{0} \mathrm{C}$, seguida de uma repetição de 40 ciclos de desnaturação a $94{ }^{0} \mathrm{C}$ por $15 \mathrm{seg}$, pareamento a $55{ }^{0} \mathrm{C}$ por $30 \mathrm{seg}$ e extensão por 1 min a $68{ }^{0} \mathrm{C}$. Terminada a reação, os tubos foram mantidos a $4{ }^{0} \mathrm{C}$.

\subsubsection{Protocolo de precipitação de DNA}

As reações de ligação e digestão foram precipitadas seguindo o protocolo, descrito a seguir, do sistema de expressão Adeno- $X^{\mathrm{TM}}$ da Clontech. O volume de cada amostra foi completado até $100 \mu \mathrm{L}$ com água Milli-Q, e foram adicionados $400 \mu \mathrm{L}$ de etanol absoluto, $25 \mu \mathrm{L}$ de $\mathrm{NH}_{4} \mathrm{Ac} 10 \mathrm{M}$ e $3 \mu \mathrm{L}$ de glicogênio $(20 \mathrm{mg} / \mathrm{mL})$. A solução foi misturada vigorosamente e incubada a $-20{ }^{0} \mathrm{C}$ por $20 \mathrm{~min}$, ou a $-80{ }^{0} \mathrm{C}$ durante $15 \mathrm{~min}$, sendo a seguir centrifugada a $14.000 \mathrm{rpm}$ durante $15 \mathrm{~min}$, a $4{ }^{0} \mathrm{C}$, o sobrenadante descartado e feita uma 
lavagem com etanol $70 \%$ a $4{ }^{0} \mathrm{C}$. O precipitado resultante foi seco a TA e o DNA ressuspendido em $15 \mu \mathrm{L}$ de água DEPC.

\subsubsection{Seqüienciamento}

Para as reações de seqüenciamento, utilizamos o kit ABI Prism ${ }^{\circledR}$ Big Dye ${ }^{T M}$ Terminator Cycle Sequencing Ready Reaction v3.1 (Applied Biosystems, Foster City, Califórnia, USA). As reações consistiam em $200 \mathrm{ng}$ de DNA em água DEPC, $3 \mu \mathrm{L}$ de sequencing buffer $5 \mathrm{X}, 3$ $\mu \mathrm{L}$ de um oligonucleotídeo 3,2 $\mu \mathrm{M}, 2 \mu \mathrm{L}$ de BigDye ${ }^{\mathrm{TM}}$ v3.1, e água DEPC até completar o volume de $15 \mu \mathrm{L}$. Os oligonucleotídeos usados no seqüenciamento foram descritos no item 3.1.5. A reação foi preparada em tubos apropriados para o termociclador Mastercycler personal da Eppendorf (Hamburgo, Alemanha), e efetuados 40 ciclos de $96{ }^{\circ} \mathrm{C}$ por $45 \mathrm{seg}, 55$ ${ }^{0} \mathrm{C}$ por 30 seg e $60{ }^{\circ} \mathrm{C}$ por 4 min. Terminada a reação, os tubos foram mantidos a $4{ }^{0} \mathrm{C}$.

Os produtos da reação de seqüenciamento foram então purificados. Aos $15 \mu \mathrm{L}$ da reação foram adicionados $25 \mu \mathrm{L}$ de uma solução de precipitação $(27,5 \mu \mathrm{L}$ de etanol, $100 \%$ gelado; 1,1 $\mu \mathrm{L}$ de NaAc 3M, pH 5,2; e 1,1 $\mu \mathrm{L}$ de glicogênio $1 \mathrm{mg} / \mathrm{mL})$. Misturou-se vigorosamente e as amostras foram mantidas em gelo por $15 \mathrm{~min}$. Centrifugou-se a $12.000 \mathrm{x} \mathrm{g}$ a TA por 20 min. O sobrenadante foi descartado e o excesso foi eliminado dando um pulso de $1.000 \mathrm{rpm}$ com o tubo invertido. Depois, foram adicionados $50 \mu \mathrm{L}$ de etanol $70 \%$. Centrifugou-se a $12.000 \mathrm{x} \mathrm{g}$ a TA por $10 \mathrm{~min}$ e o sobrenadante foi descartado. As amostras foram incubadas a $95{ }^{0} \mathrm{C}$ por 2 min para secar o precipitado e em seguida os tubos foram selados e guardados a $20{ }^{0} \mathrm{C}$ protegidos da luz.

Após esse procedimento as reações foram enviadas para o Serviço de Seqüenciamento de DNA do Instituto de Química da USP. O resultado do seqüenciamento foi comparado a seqüencias anteriormente publicadas, utilizando o programa DNASTAR Lasergene® e também pelo sítio do NCBI/BLAST.

\subsubsection{Eletroforese em gel de agarose}

A análise das amostras de DNA foi feita através de eletroforese em gel de agarose adicionando-se às amostras 1/6 do volume de tampão de amostra para eletroforese (azul de bromofenol 0,25\%; xyleno cyanol 0,25\%; glicerol 30\%; em água). Os géis foram preparados 
utilizando-se agarose (Invitrogen ${ }^{\mathrm{TM}}$ ) em concentrações de 0,7\%, 1,0\% ou 1,5\% em tampão TBE 0,5 X (Tris-borato $45 \mathrm{mM}$; EDTA $1 \mathrm{mM}$ ). A eletroforese foi realizada a TA, a uma voltagem constante $(4 \mathrm{~V} / \mathrm{cm})$. Ao finalizar a corrida, o gel foi transferido para um recipiente com água desionizada, contendo brometo de etídio $(10 \mu \mathrm{g} / \mathrm{mL})$ e incubado por $20 \mathrm{~min}$. O gel foi visualizado em um trans iluminador de luz ultravioleta.

\subsubsection{SDS-PAGE}

A análise de amostras de proteínas foi feita mediante SDS-PAGE conforme o protocolo descrito por Laemmli (1970). As amostras foram misturadas com igual volume de tampão de amostra SDS $2 \mathrm{X}$ (Tris-HCl $125 \mathrm{mM}, \mathrm{pH}$ 6,8; 2-mercaptoetanol 2\%; SDS 4\%; azul de bromofenol 0,1\%; Glicerol 20\%) e fervidas por 15 min. Após a aplicação das amostras no gel, as mesmas foram submetidas a uma corrente elétrica constante de $30 \mathrm{~mA}$. Finalizada a corrida, os géis seguiram para coloração com solução de Coomasie (metanol 50\%, Coomasie Brilliant Blue R-250 0,05\%, ácido acético 10\%) por 2 hs. Os géis foram descorados durante 16 hs em solução descolorante (ácido acético 10\%). Para a realização de Western Blot os géis não foram corados e seguiram para transferência.

\subsubsection{Ensaio Western Blot}

Amostras de proteínas foram resolvidas em SDS-PAGE e, finalizada a corrida, as proteínas dos géis foram transferidas a membranas de nitrocelulose (Amersham Biosciences, Little Chalfon, Inglaterra). As membranas foram bloqueadas durante $16 \mathrm{hs} \mathrm{a} 4{ }^{0} \mathrm{C}$ em tampão de bloqueio (PBS, Tween-20 0,1\%, leite desnatado 5\%). A seguir, a membrana foi incubada durante $1 \mathrm{~h}$ com o anticorpo primário em diluição apropriada em tampão de bloqueio. Após 3 lavagens por 5 min e agitação com tampão de lavagem (PBS, Tween-20 0,1\%), a membrana foi incubada durante $1 \mathrm{~h}$ com o anticorpo secundário em diluição apropriada em tampão de bloqueio. Após 3 lavagens nas mesmas condições especificadas anteriormente as bandas foram visualizadas com o kit West Pico Supersignal (Pierce, Rockford, Illinois, USA) (Harlow e Lane, 1988). 


\subsubsection{Obtenção de pó cetônico}

Garrafas de $75 \mathrm{~cm}^{2}$ com cultura de células HEK-293T confluentes, o meio foi retirado e a monocamada foi lavada com PBS duas vezes. Depois foram acrescentados $5 \mathrm{~mL}$ de PBSEDTA $10 \mathrm{mM}$ e as garrafas foram incubadas por $10 \mathrm{~min}$ a $37{ }^{0} \mathrm{C}$. Em seguida, as células foram raspadas com rodo e a suspensão celular proveniente de uma área de $150 \mathrm{~cm}^{2}$ foi colocada em um tubo Falcon de $15 \mathrm{~mL}$. As células foram centrifugadas a $1.200 \mathrm{x} \mathrm{g}, 10 \mathrm{~min}$ a $4{ }^{0} \mathrm{C}$ e o sedimento celular foi ressuspendido em $800 \mu \mathrm{L}$ de PBS e transferido a dos tubos eppendorf de $1,5 \mathrm{~mL}$. As células foram centrifugadas novamente a $500 \mathrm{x}$ g por $5 \mathrm{~min}$ e o sedimento foi ressuspendido em $200 \mu \mathrm{L}$ de PBS. Foram adicionados $800 \mu \mathrm{L}$ de acetona a -20 ${ }^{0} \mathrm{C}$ à suspensão celular, misturou-se vigorosamente e incubou-se no gelo por $30 \mathrm{~min}$ com agitação vigorosa ocasional. A suspensão de células foi centrifugada a 10.000 x g por 10 min a $4{ }^{0} \mathrm{C}$, o sobrenadante foi descartado e o sedimento foi ressuspendido em $1 \mathrm{~mL}$ de acetona a $20{ }^{0} \mathrm{C}$, agitado vigorosamente, e após $10 \mathrm{~min}$ de repouso foi centrifugada a $10.000 \mathrm{x}$ g por 10 min a $4{ }^{0} \mathrm{C}$. O sobrenadante foi descartado e o sedimento foi secado incubando o tubo aberto a $37{ }^{0} \mathrm{C}$ por $15 \mathrm{~min}$, e pulverizado mecanicamente com a ponta de uma ponteira contra o fundo do tubo.

\subsubsection{Adsorção de soros}

Os soros policlonais obtidos foram diluídos 1:5 em PBS, e 30 a $50 \mathrm{~mL}$ foram adicionados às alíquotas de pó de células obtidas anteriormente, e incubados por 30 min a 4 ${ }^{0} \mathrm{C}$ sob agitação. Após esse tempo, o tubo foi centrifugado a $10.000 \mathrm{x}$ g por 10 min a $4{ }^{0} \mathrm{C}$. O sobrenadante foi coletado e usado como fonte de anticorpos.

\subsubsection{Imunofluorescência}

Para realizar o ensaio, células HEp-2 ou HEK-293 T foram semeadas em placas de 96 poços. Após terem sido submetidas a algum tratamento, ou não, o meio foi removido, as células lavadas $2 \mathrm{X}$ com PBS, e em seguida fixadas com $100 \mu \mathrm{L}$ por poço de metanol por 2 min a TA. Após esse tempo a monocamada celular foi lavada 2X com PBS e bloqueada com $100 \mu \mathrm{L}$ por poço do tampão de bloqueio (PBS-Tween $200,2 \%$ e leite desnatado $3 \%$ ) a $37{ }^{0} \mathrm{C}$ por 20 min. Para detectar a proteína de interesse foram adicionados $70 \mu \mathrm{L}$ do anticorpo 
primário na diluição apropriada em solução de bloqueio, por $1 \mathrm{~h}$ a $37{ }^{0} \mathrm{C}$, seguindo-se 3 lavagens com PBS-Tween-20 0.2\%, incubação com $70 \mu \mathrm{L}$ de anticorpo secundário anti-IgG conjugado com um fluoróforo, diluído na solução de bloqueio, por $1 \mathrm{~h}$ a $37{ }^{0} \mathrm{C}$. A visualização do núcleo foi feita pela coloração com 4',6-diamidino-2-phenylindole (DAPI). Este último foi incubado junto com o anticorpo secundário a uma concentração final de $5 \mathrm{ng} / \mu \mathrm{L}$. Após lavagens como descrito acima, as células foram observadas num microscópio de fluorescência Axiovert 200 da Zeiss ${ }^{\mathrm{TM}}$.

\subsection{Metodologia específica}

\subsubsection{Amplificação dos estoques virais e titulação}

Placas de cultura de $10 \mathrm{~cm}$ de diâmetro com células HEp-2 a 70-80\% de confluência foram inoculadas com o protótipo A do HRSV (cepa A2), gentilmente cedido pela Dra. Marilda Siqueira (Departamento de Virologia da Fundação Oswaldo Cruz, Rio de Janeiro, Brasil). O meio de crescimento foi removido e foi acrescentado o vírus diluído em meio de infecção (meio MEM suplementado com SFB 2\%, $100 \mu \mathrm{g} / \mathrm{mL}$ de gentamicina e $8 \mu \mathrm{g} / \mathrm{mL}$ de Tylosina) a uma multiplicidade de infecção (MOI) de 1UFS (unidades formadoras de sincício) / célula. O vírus foi deixado em adsorção incubando por 2 hs a $37{ }^{0} \mathrm{C}$. Após esse tempo o meio foi reconstituído a um volume final de $8 \mathrm{~mL}$ por placa, seguindo incubação e observação periódica. As culturas que apresentaram o efeito citopático característico de formação de sincícios foram coletadas de 36 a 44 hs após infecção. Para tanto, a monocamada foi lavada $1 \mathrm{X}$ com PBS, PBS com EDTA $10 \mathrm{mM}$ foi adicionado, incubou-se a $37{ }^{0} \mathrm{C}$ por 10 min, as células foram coletadas por raspagem, transferidas a tubos Falcon de $15 \mathrm{~mL}$ e centrifugadas a $1.200 \mathrm{x} \mathrm{g} \mathrm{a} 4{ }^{0} \mathrm{C}$ por $10 \mathrm{~min}$. O sobrenadante foi descartado e o sedimento foi ressuspendido em PBSS (PBS, sacarose 30\% e SFB2\%). A suspensão foi colocada num dounce (tight), submetida à lise 15 vezes e o homogeneizado resultante foi centrifugado a $2.000 \mathrm{x}$ g. O sobrenadante obtido foi estocado a $-80{ }^{\circ} \mathrm{C}$ em alíquotas de $50 \mu \mathrm{L}$ ou concentrado por ultracentrifugação. Para isso a suspensão viral foi diluída (1:1) em solução de NTE (NaCl 150mM, Tris-HCl 50mM, EDTA $1 \mathrm{mM}$ ) mais sacarose $30 \%$. Quatro $\mathrm{mL}$ da mistura foram adicionados a tubos de $5 \mathrm{~mL}$ (PA, THINWALL, Sorvall ${ }^{\mathrm{TM}}$ ) e ultracentrifugados em rotor AH650 a $35.600 \mathrm{rpm}$ por $3 \mathrm{hs} \mathrm{a} 4{ }^{0} \mathrm{C}$. Finalizada a centrifugação o sedimento contendo vírus foi ressuspendido em $1 \mathrm{~mL}$ de PBSS e armazenado a $-80{ }^{0} \mathrm{C}$ em alíquotas de $20 \mu \mathrm{L}$. 
O título, tanto das suspensões virais obtidas, quanto do vírus purificado foi obtido realizando diluições seriadas na base 10 em meio de infecção. Células HEp-2 cultivadas em placas de cultura de 96 poços a uma confluência de $70-80 \%$ foram infectadas $(100 \mu \mathrm{L}$ de cada diluição por poço), em duplicata. As placas foram incubadas de 1 a 2 hs para adsorção e transcorrido este tempo o meio foi reconstituído até $200 \mu \mathrm{L}$. Foi observado o efeito citopático por microscopia o qual ficou evidente 48 hs após infecção.

Verificou-se a presença do vírus por imunofluorescência seguindo o protocolo descrito no item 3.1.18. Para detectar as proteínas virais na monocamada infectada foi utilizado o anticorpo monoclonal anti-G C793 (gentilmente cedido pelo Dr. Erling Norrby do Karolinska Institute, Estocolmo (Orvell et al., 1987)) diluído 1:500. Utilizamos como anticorpo secundário anti-IgG de camundongo conjugado com isotiocianato de fluoresceina (FITC) (KPL) diluído 1:50. O título foi expresso como UFS/mL.

\subsubsection{Predição de epítopos da proteína $L$}

Foram usados os programas de predição de epítopos SYFPEITHI (http://www.syfpeithi.de/home.htm) e PRED ${ }^{\text {BALB/C }}$ (http://antigen.i2r.a-star.edu.sg/ predBalbc/), os quais avaliam a probabilidade de ligação dos peptídeos às moléculas MHC. O SYFPEITHI inclui os alelos da molécula do MHC-I H- $2 \mathrm{~K}^{\mathrm{d}}$ e $\mathrm{H}-2 \mathrm{~L}^{\mathrm{d}}$ de camundongo Balb/c. Já o PRED ${ }^{\mathrm{BALB} / \mathrm{C}}$ é específico para o MHC de camundongos dessa linhagem contemplando: $\mathrm{H}-2 \mathrm{D}^{\mathrm{d}}, \mathrm{K}^{\mathrm{d}}$ e $\mathrm{L}^{\mathrm{d}}$. Para a análise foi empregada a sequiência da proteína $\mathrm{L}$ da cepa protótipo do HRSV do subtipo A (cepa A2) (tabela 1). Analisamos peptídeos de 9 aa, e os prediptopes com maior escore de ligação ao MHC-I foram pré-selecionados (8 para $\operatorname{PRED}^{\mathrm{BALB} / \mathrm{C}}$ e 23 para syfpeithi) e organizados em ordem decrescente de escore para cada programa. Os resultados para cada programa foram combinados (predição consenso). Por último, foram utilizados dois critérios para a seleção de prediptopes: seqüências que contêm peptídeos de 9-mer com alto escore de ligação ao MHC-I; e o grau de conservação entre os diferentes grupos, realizando alinhamento de seqüências da proteína L de 7 cepas de HRSV (tabela 1) com o programa CLUSTAL V. 
Tabela 1- Lista das sequiências da proteína L utilizadas.

\begin{tabular}{c|l|l}
\hline Grupo & Número da seqüência & Observações \\
\hline \multirow{3}{*}{ A } & $\begin{array}{l}\text { AAA47418.1-gi/1143829/gb } \\
\text { AAA84898.1-gi/333955 } \\
\text { AAC 57029.1-gi/1912297 } \\
\text { AY911262-gi/60549163 } \\
\text { AF254574-gi/7960297 }\end{array}$ & $\begin{array}{l}\text { cepa A2 } \\
\text { cepa S2 } \\
\end{array}$ \\
\hline \multirow{2}{*}{ B } & $\begin{array}{l}\text { AF013254-gi/2582022 } \\
\text { NP_001781-gi/9629198 }\end{array}$ & ATCC VR-26 \\
& AY353550-gi/38230482 & cepa selvagem B1 \\
\hline
\end{tabular}

Fonte: Medina-Armenteros (2012)

Uma vez selecionados, foi encomendada a síntese dos peptídeos à empresa BACHEM, com um grau de pureza de $81 \%$, diluídos a $1 \mathrm{mg} / \mathrm{mL}$ em água estéril contendo $5-10 \%$ de dimetil sulfóxido e armazenados a $-80{ }^{\circ} \mathrm{C}$.

\subsubsection{Avaliação da resposta imune celular}

\subsubsection{Imunizacão de camundongos}

Para avaliar a resposta de linfócitos do baço contra os peptídeos, camundongos Balb/c fêmeas com 6 a 8 semanas de idade, foram obtidos junto ao biotério de animais isogênicos do ICB-USP. Os animais foram anestesiados previamente ao procedimento pela aplicação de 350 $\mu \mathrm{l}$ de anestésico (PBS, Ketamina 0,6\%, Xilazina 0,08\%). A imunização com os peptídeos foi realizada segundo o protocolo descrito por Liu e colaboradores com algumas modificações (Liu et al., 2007). Os animais (4 ou 5 por grupo) foram imunizados com 4 doses de $20 \mu \mathrm{g}$ do peptídeo correspondente, diluído em PBS, com intervalo de 1 semana (figura 9). O volume do inóculo foi de $100 \mu \mathrm{L}$ contendo $50 \mu \mathrm{L}$ de adjuvante. A primeira dose foi administrada com adjuvante completo de Freund (CFA) via subcutânea e as 3 doses restantes foram administradas via intraperitoneal, em adjuvante incompleto de Freund (IFA). Um grupo controle foi imunizado apenas com PBS mais adjuvante. 
Figura 9- Esquema de ensaio de imunização com peptídeos.

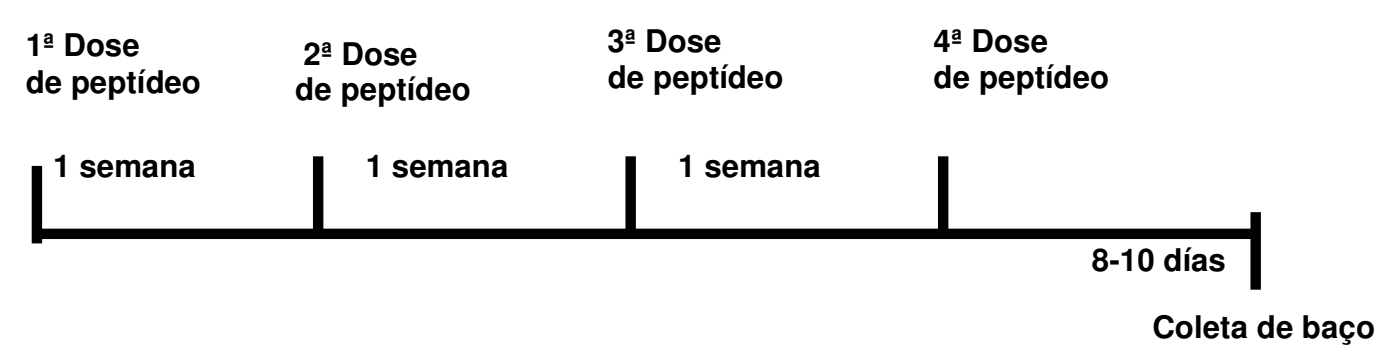

$\mathrm{Na}$ figura está indicado o intervalo entre as doses administradas e a coleta de baço.

Fonte: Medina-Armenteros (2012)

Para avaliar a resposta de linfócitos pulmonares contra os peptídeos, os camundongos foram infectados com 20 a $50 \mu \mathrm{L}$ da cepa de desafio HRSV A2 (1x10 ${ }^{6}$ UFS em PBSS) intranasalmente, usando micropipeta. A infecção foi realizada duas vezes com intervalo de 10 a 12 dias. Um grupo controle foi imunizado apenas com PBSS.

\subsubsection{Isolamento do vírus do pulmão}

Cinco dias após infecção com HRSV, os animais foram sacrificados e o pulmão foi coletado em meio de lavagem (RPMI suplementado com SFB 1\%, $100 \mu \mathrm{g} / \mathrm{mL}$ de gentamicina e $8 \mu \mathrm{g} / \mathrm{mL}$ de Tylosina). O órgão foi lavado em meio RPMI, fragmentado e homogeneizado no dounce (loose) em PBSS. O homogeneizado foi colocado num tubo falcon de $15 \mathrm{~mL}$ e centrifugado no rotor angular Jouan 11174593 a $4.000 \mathrm{rpm}$ por $15 \mathrm{~min}$ a $4{ }^{0} \mathrm{C}$. O sobrenadante foi recuperado e a presença do vírus foi analisada detectando a proteína de matriz $\mathrm{M}$ do HRSV mediante Western Blot como explicado no item 3.1.15. Foi usado como anticorpo primário um policlonal anti-M obtido em camundongos anteriormente no laboratório, diluído 1:5.000 e, como secundário, um anti-IgG de camundongo conjugado à peroxidase (Sigma) diluído a 1:3.000. 


\subsubsection{Obtenção de células do baço}

Os baços foram retirados cirurgicamente em condições assépticas e dispostos em placas de petri individuais, contendo $2 \mathrm{~mL}$ de meio de lavagem, onde foram macerados com êmbolo para soltar as células. A seguir, as células foram recuperadas e lavadas por centrifugação a $1.000 \mathrm{x}$ g por $10 \mathrm{~min}$. $\mathrm{O}$ sobrenadante foi descartado e foram adicionados $5 \mathrm{~mL}$ de tampão ACK $\left(\mathrm{NH}_{4} \mathrm{Cl}\right.$ 0,15 M, $\mathrm{KHCO}_{3} 1 \mathrm{mM}$, EDTA 0,1 mM; pH 7,4) ao sedimento celular para lisar as hemácias. Após incubação a $4{ }^{0} \mathrm{C}$ por $10 \mathrm{~min}$, as células foram lavadas duas vezes. $\mathrm{O}$ sobrenadante foi descartado e as células foram ressuspendidas em $1 \mathrm{~mL}$ de meio completo (RPMI suplementado com $10 \%$ de SFB, $100 \mu \mathrm{g} / \mathrm{mL}$ de gentamicina, $1 \mathrm{mM}$ de L-glutamina, $0,11 \mathrm{mg} / \mathrm{mL}$ de piruvato de sódio, $5 \times 10^{-5} \mathrm{M}$ de $\beta$-mercaptoetanol, solução de vitaminas $1 \mathrm{X}$ e de aminoácidos 1X, ambas da GIBCO).

\subsubsection{Obtencão de células do pulmão}

Os pulmões dos animais foram retirados cirurgicamente e dispostos em placas de petri individuais, contendo $2 \mathrm{~mL}$ de meio de lavagem. Eles foram lavados 2 vezes, cortados e colocados em um frasco novo com tampa com meio de lavagem ( $2 \mathrm{~mL}$ por pulmão). Em seguida foram submetidos à digestão com a enzima Colagenase tipo IV (440U/mg) da Sigma, a uma concentração final de $(1 \mathrm{mg} / \mathrm{mL})$. A reação foi realizada na presença de $\mathrm{CaCl}_{2} 5 \mathrm{mM}$, incubando a $37{ }^{0} \mathrm{C}$ por $1 \mathrm{~h}$ com agitação. Após esse tempo, a reação foi parada inativando a enzima com EDTA $10 \mathrm{mM}$ e incubando 5 min no gelo. A suspensão celular resultante foi transferida para tubos de $15 \mathrm{~mL}$ e centrifugada a $1.000 \mathrm{x}$ g por $15 \mathrm{~min}$. Coletou-se o sedimento onde estavam as células, e foram tratadas com $1 \mathrm{~mL}$ de tampão ACK incubando a 4 ${ }^{0} \mathrm{C}$ por 10 min. A partir dai procedeu-se como o descrito no item 3.2.3.3.

\subsubsection{Ensaios de liberação de IFN- $\gamma$}

\subsection{ELISPOT}

A imunogenicidade dos peptídeos foi avaliada por meio de ensaio ELISPOT de liberação de IFN- $\gamma$. Sete a doze dias após a última inoculação, os baços e pulmões dos animais imunizados ou infectados foram coletados, e foi obtida uma suspensão de células do baço e do 
pulmão como descrito nos itens 3.2.3.3 e 3.2.3.4, respectivamente. Para realizar o ensaio placas MultiScreen da Millipore ${ }^{\mathrm{TM}}$ foram pré-sensibilizadas adicionando $60 \mu 1 /$ poço de um anticorpo de captura anti-IFN- $\gamma$ (BD Pharmingen ${ }^{\mathrm{TM}}, 10 \mu \mathrm{g} / \mathrm{mL}$ ) e incubando por 16 a $24 \mathrm{hs}$ a TA. Transcorrido este tempo, as placas foram lavadas 3 vezes com $200 \mu \mathrm{L}$ de meio de lavagem e bloqueadas com $100 \mu \mathrm{L} /$ poço de meio RPMI suplementado com SFB 10\%, seguido de incubação a $37{ }^{0} \mathrm{C}$ por $2 \mathrm{hs}$. Uma vez que as placas estavam prontas, as células do baço obtidas foram semeadas a uma densidade de $5 \times 10^{5}$ células/poço, re-estimuladas ex vivo com o peptídeo correspondente (250ng/poço) e incubadas por 24 a 30 hs a $37{ }^{\circ} \mathrm{C}$. Após esse tempo, as células foram descartadas e as placas foram lavadas 3 vezes com PBS e 5 com PBSTween-20 0,05\%. Em seguida, foram adicionados 75 $\mu \mathrm{L} /$ poço de um segundo anticorpo antiIFN- $\gamma$ biotinilado (BD Pharmingen ${ }^{\mathrm{TM}}, 2 \mu \mathrm{g} / \mathrm{mL}$ ), incubando-se a $4{ }^{0} \mathrm{C}$ overnight $(\mathrm{ON})$ protegido da luz. As placas foram lavadas 6 vezes com PBS-Tween-20 0,05\%. O segundo anticorpo foi reconhecido mediante a aplicação do conjugado streptavidina-peroxidase $(100 \mu \mathrm{l} /$ poço a $2 \mu \mathrm{g} / \mathrm{ml})$ e incubação por 3 hs a TA seguido de 5 lavagens com PBS-tween-20 0,05\% e 3 com PBS. A detecção das células secretoras de IFN- 7 foi feita por meio da adição de $100 \mu \mathrm{L}$ da solução de revelação: $50 \mathrm{mM}$ de Tris- $\mathrm{HCl}, \mathrm{pH} 7,5$ contendo $\mathrm{H}_{2} \mathrm{O}_{2}(0,03 \%)$ e o cromógeno 3,3'-diaminobenzidina $(1 \mathrm{mg} / \mathrm{mL})$ para desenvolver a coloração e formação de spots correspondentes a células secretoras de IFN-ry (Simmons et al., 2005). Para determinar se os linfócitos T CD8+ eram os responsáveis pela liberação do IFN- $\gamma$, foi realizado o mesmo ensaio ELISPOT acrescentando ao sistema $1 \mu \mathrm{g} /$ poço do anticorpo anti-CD8a MCD0800 (Invitrogen ${ }^{\mathrm{TM}}$ ) junto com os peptídeos. Foi analisada a formação de spots por células estimuladas com o peptídeo homólogo na ausência e na presença do anticorpo anti-CD8. O número de spots específicos após estimulação com o peptídeo homólogo foi calculado subtraindo o número de spots produzidos pelas células estimuladas menos o número de spots sem estimular, na presença ou ausência do anticorpo anti-CD8. A contagem dos spots foi feita em estereoscópio SMZ645 da Nikon ${ }^{\mathrm{TM}}$.

\subsection{Marcação intracelular de citocina}

Após a obtenção da suspensão das células do baço elas foram semeadas em placas de 96 poços a uma concentração de $1 \times 10^{6}$ células/poço. O meio foi completado para $200 \mu \mathrm{L}$ e foram adicionados 250ng/poço do peptídeo correspondente para reestimular ex vivo a síntese do IFN- $\gamma$. As células foram incubadas por 3 hs a $37{ }^{0} \mathrm{C}$ e, após esse tempo foi acrescentada $1 \mu \mathrm{g}$ 
de brefeldina A por poço, e incubadas $\mathrm{ON}$ a $37{ }^{\circ} \mathrm{C}$. Finalizado este período, as células foram coletadas por centrifugação a 1.200 x g a $4{ }^{0} \mathrm{C}$, lavadas com PBS (200 $\mu 1$ /poço com SFB $\left.1 \%\right)$, centrifugadas, ressuspendidas em $50 \mu 1$ de solução de um anticorpo monoclonal anti-CD8 diluído 1:100 (PE-Cy ${ }^{\mathrm{TM}_{5}}$ Rat Anti-Mouse CD8a da BD Pharmingen ${ }^{\mathrm{TM}}$ ), e incubadas por 30 min a $4{ }^{0} \mathrm{C}$. Após lavagem, as células foram fixadas com paraformaldeido $4 \%$ a $4{ }^{0} \mathrm{C}$ por 15 min, seguindo-se uma lavagem. Antes de colocar o segundo anticorpo as células foram incubadas com tampão de permeabilização (PBS Dulbecco, BSA 0,2\%, azida sódica 0,1\%, saponina $0,5 \%$, pH 7,5) por 10 min a $4{ }^{0} \mathrm{C}$, seguindo-se uma lavagem. A segunda marcação foi realizada com um anticorpo monoclonal anti-IFN- $\gamma$ (R-Phycoerythrin-conjugated Rat Anti-Mouse IFN- $\gamma$ da BD Pharmingen ${ }^{\mathrm{TM}}$ ) diluído 1:100 (incubação de 30 min a $4{ }^{0} \mathrm{C}$ ). Por último, as células foram lavadas 2 vezes e adicionados mais $200 \mu \mathrm{L}$ de PBS com SFB $1 \%$ para contagem. A resposta de células TCD8+ secretoras de IFN- $\gamma$ estimuladas com os peptídeos testados foi medida por citometría de fluxo num citômetro BD FACSCalibur. Foi analisada a emissão de fluorescência para cada um dos fluoróforos usados. O resultado foi considerado positivo quando a porcentagem de células $\mathrm{CD} 8+\mathrm{IFN}-\gamma+$ de células estimuladas ex vivo menos as não estimuladas foi $\geq 0.6$.

\subsubsection{Produção de proteínas recombinantes}

\subsubsection{Expressão e purificacão de proteínas}

A produção das proteínas CTB e GMCTB foi realizada a partir dos vetores bacterianos, pAE-ctxB e pAE-ctxB-GM, respectivamente (ver mapas no item 3.1.4). Para isso bactérias BL21(DE3) foram transformadas com um dos plasmídios mencionados e cultivadas em meio LB suplementado com ampicilina. Após atingir uma $\mathrm{DO}_{600}$ de 0,6 foi feita a indução da expressão acrescentando-se ao meio IPTG a uma concentração final de $0.5-1 \mathrm{mM}$ e as bactérias foram incubadas por 4 hs a $37{ }^{\circ} \mathrm{C}$. Finalizada a indução, a cultura foi centrifugada a $10.000 \mathrm{x}$ g por 10 min para obtenção do precipitado bacteriano, o qual foi ressuspendido em tampão Tris/ $\mathrm{NaCl}$ (Tris $0,1 \mathrm{M}, \mathrm{NaCl} 0,5 \mathrm{M}, \mathrm{pH} 8$ ou 8,5), lisado com french-press e centrifugado a $10.000 \mathrm{x}$ g por $50 \mathrm{~min}$ a $4{ }^{0} \mathrm{C}$. O precipitado obtido foi ressuspendido em $60 \mathrm{ml}$ de tampão com uréia (Tris- $\mathrm{HCl} 0,1 \mathrm{M}, \mathrm{NaCl}$ 0,5 M, Uréia 8M, Imidazol 0,02 M, pH 8 ou 8,5) e a amostra assim tratada foi incubada durante 16 hs a TA com agitação. A seguir, o material insolúvel foi eliminado por centrifugação a 10.000 x g por 30 min. A renaturação das 
proteínas recombinantes foi realizada pelo método de diluição. Para tanto, as proteínas em solução de uréia foram diluídas em $2 \mathrm{~L}$ de tampão A (Tris- $\mathrm{HCl}$ 0,1 M, NaCl 0,5 M, Imidazol $0,02 \mathrm{M}, \mathrm{pH} 8$ ou 8,5) por gotejamento a um fluxo de $200 \mu \mathrm{L} / \mathrm{min}$. As amostras de proteínas assim tratadas foram purificadas por cromatografia de afinidade em coluna carregada com resina de $\mathrm{Ni}^{+}$, pelo fato de que as construções possuem uma cauda de 6 Histidinas no Nterminal segundo protocolo anteriormente descrito (Arêas et al., 2002). As frações de purificação foram analisadas mediante SDS-PAGE e Western Blot. As proteínas foram quantificadas utilizando o kit Quick Start ${ }^{\mathrm{TM}}$ Bradford Protein Assay (Bio-Rad).

Além das duas proteínas recombinantes, foi encomendada a síntese do peptídeo GM de 41 aa (HFEVFNFVPCSICSNNPTCWAICGRGPNGKPGKKTTTKPTK). Ele abrange os resíduos 164-204 dentro do ectodomínio não glicosilado conservado da glicoproteína G com os aa lisina (187), isoleucina (189) e lisina (192) substituídos por glicina (em azul). O peptídeo foi sintetizado pela Invitrogen ${ }^{\mathrm{TM}}$ com uma pureza de $96,44 \%$, diluído a $1 \mathrm{mg} / \mathrm{mL}$ em água estéril, aliquotado e armazenado a $-80{ }^{\circ} \mathrm{C}$.

\subsubsection{Deteccão de proteínas por Western Blot}

Amostras de proteínas foram resolvidas em SDS-PAGE tanto em condições desnaturantes quanto em não desnaturantes (Laemmli, 1970), e a seguir procedeu-se como descrito nos itens 3.1.14 e 3.1.15. Para a detecção das proteínas CTB e GMCTB utilizou-se um anticorpo policlonal anti-CTB (Arêas et al., 2002) diluído a 1:7.000, e como secundário, um anticorpo anti-IgG de coelho conjugado à peroxidase (Invitrogen ${ }^{\mathrm{TM}}$ ), diluído a 1:2.000.

\subsubsection{Análise da funcionalidade de CTB e GMCTB}

Uma vez renaturadas as proteínas CTB e GMCTB e conferida a formação de pentâmeros por SDS-PAGE em condições não desnaturantes seguido de imunoblotting com anticorpo anti-CTB, foi analisada a capacidade desses pentâmeros de se ligarem ao receptor gângliosídeo GM1 por meio de um ELISA. Para isso, placas de 96 poços (NUNC $^{\mathrm{TM}}$, Roskilde, Dinamarca) foram sensibilizadas com $100 \mathrm{ng}$ de GM1 num volume de $100 \mu \mathrm{L}$ por poço e incubadas a $37{ }^{0} \mathrm{C}$ por 4 hs. As placas foram lavadas duas vezes com PBS, bloqueadas com tampão de bloqueio (PBS contendo BSA 0.1\%) a $37{ }^{0} \mathrm{C}$ por $30 \mathrm{~min}$. As placas foram lavadas novamente duas vezes com PBS, e foram adicionados $100 \mu \mathrm{L}$ a cada poço das diluições seriadas das proteínas purificadas, e incubadas por 2 hs a TA. As placas foram 
lavadas 3 vezes com PBS Tween-20 0,05\%. A detecção das proteínas ligadas foi realizada com anticorpo policlonal de coelho anti-CTB diluído 1:1000 (incubação por 1h e 30 min). Após mais 3 lavagens, foi adicionado um segundo anticorpo anti-IgG de coelho conjugado à peroxidase diluído 1:2.000, o qual foi incubado nas mesmas condições. A revelação foi realizada com $200 \mu \mathrm{L}$ de solução de substrato (ácido cítrico 24,4 mM, $\mathrm{Na}_{2} \mathrm{HPO}_{4} 48,8 \mathrm{mM}$, ortofenilenodiamina $0,8 \mathrm{mg} / \mathrm{mL}, \mathrm{H}_{2} \mathrm{O}_{2}$ 0,045\%). As placas foram incubadas 10 min no escuro e posteriormente foram adicionados $25 \mu \mathrm{L}$ por poço de solução de $\mathrm{H}_{2} \mathrm{SO}_{4} 2 \mathrm{M}$ para parar a reação. Finalmente, mediu-se a absorbância de cada poço a 492 nm.

\subsubsection{Concentracão de proteínas}

As proteínas foram concentradas em filtros Amicon $^{\mathrm{TM}}$ de 50,30 e 3 KDa, sucessivamente. Os filtros foram previamente tratados com água desionizada e a seguir PBS. Em cada ciclo de concentração pelos filtros de diferentes tamanhos de poros, foram adicionados $4 \mathrm{~mL}$ da suspensão de proteína e centrifugados num rotor swing a $4.000 \mathrm{rpm}, 23$ ${ }^{0} \mathrm{C}$, por $20 \mathrm{~min}$. O concentrado final (filtro de $3 \mathrm{KDa}$ ) foi analisado em eletroforese em gel de acrilamida $15 \%$ desnaturante ou não. A concentração foi determinada pelo método de Bradford usando o Quick Start Bradford Dye Reagent da BIO-RAD, seguindo o protocolo de microplacas.

\subsubsection{Obtenção das vacinas de DNA}

\subsubsection{Obtencão do plasmídio pT}

Para construir o plasmídio pT, a sequiência sinal do ativador de plasminogênio tecidual (TpA) foi obtida digerindo $20 \mu \mathrm{g}$ do plasmídio pE3 com HindIII e EcoRV, o qual contém a sequiência de interesse clonada entre esses sítios (gentilmente cedido pela Dra. Ada Maria de Barcelos Alves, Fundação Oswaldo Cruz, Rio de Janeiro, Brasil). O fragmento digerido foi purificado por meio de eletroforese em gel de acrilamida $15 \%$ e a banda de interesse foi cortada do gel e submetida a eletroeluição em tampão TAE a $10 \mathrm{~V}$ por $2 \mathrm{hs}$ e $30 \mathrm{~min}$. O fragmento de DNA foi precipitado dessa solução e subclonado em pcDNA3 entre os sítios HindIII e EcoRV gerando o vetor pT. O fragmento de DNA purificado foi misturado com o plasmídio pcDNA3 previamente digerido com essas enzimas, e incubados a $16{ }^{0} \mathrm{C}$ ON na presença da enzima T4 DNA ligase (NEB). A reação de ligação foi precipitada (ver item 
3.1.11), o precipitado foi lavado com etanol $70 \%$ e ressuspendido em 10 a $20 \mu \mathrm{L}$ de água DEPC. Bactérias E. coli DH10B foram transformadas, selecionadas com ampicilina, e os plasmídeos obtidos das colônias purificados (ver itens 3.1.7 e 3.1.8). O DNA obtido foi submetido à digestão dupla com as enzimas de restrição para diferenciar os plasmídios contendo o TpA dos não recombinantes, e analisado por eletroforese em gel de poliacrilamida $15 \%$ e posterior detecção do fragmento correspondente por coloração com brometo de etídio. Os clones bacterianos positivos foram amplificados em 100mL de meio LB com ampicilina, sendo o DNA purificado por coluna de afinidade usando o Kit HiPure Plasmid Midiprep da Invitrogen $^{\mathrm{TM}}$. As amostras purificadas foram seqüenciadas (ver item 3.1.12) usando oligonucleotídeos que amplificam sequiências do vetor pcDNA3 descritos no item 3.1.5.

\subsubsection{Obtenção dos plasmídios pTGM, pTCTB e pTGMCTB}

Para obter as vacinas de DNA, as sequiências de nucleotídeos de GM, ctxB e ctxB-GM foram amplificadas a partir do plasmídio pAE-ctxB-GM. Os genes foram submetidos a PCR com os oligonucleotídeos: GM, TPGF e TPGR; $\mathbf{c t x B}$, TPCTF e TPCTR; e ctxB-GM, TPGF e TPCTR (ver item 3.1.5). Esses produtos de amplificação foram purificados em gel de agarose $2 \%$ usando o Kit Quick Gel Extraction da Invitrogen ${ }^{\mathrm{TM}}$, e digeridos com as enzimas de restrição EcoRV e XbaI. A seguir foram misturados com o plasmídio pT previamente digerido com as mesmas enzimas, seguindo o procedimento de ligação, transformação e seleção de clones bacterianos, como descrito no item anterior.

No screening de clonagem o DNA obtido foi submetido à digestão com enzimas de restrição para diferenciar os plasmídios contendo o GM, ctxB ou ctxB-GM dos não recombinantes, como será apresentado adiante em resultados. A análise das digestões foi por eletroforese em gel de agarose $1 \%$ e posterior detecção do padrão de bandas de DNA por coloração com brometo de etídio. As amostras purificadas foram seqüenciadas (ver item 3.1.12) usando tanto os oligonucleotídeos que hibridam tanto nas seqüências do vetor pcDNA3 quanto nos genes clonados (ver item 3.1.5). Com esse procedimento foram gerados pTGM, pTCTB e pTGMCTB (ver mapas no item 3.1.4). 


\subsubsection{Ensaio de transfeccão}

Células HEK-293T foram crescidas em placas de 96 poços até atingirem a confluência de $90 \%$. Foram misturadas 144ng de cada plasmídio (pT, pTGM, pTCTB ou pTGMCTB) a $800 \mathrm{ng}$ de lipofectamina (Invitrogen ${ }^{\mathrm{TM}}$ ), em meio MEM, por poço. O meio de crescimento foi substituído pelo de transfecção e as células foram incubadas por $3 \mathrm{hs,} \mathrm{sendo} \mathrm{a} \mathrm{seguir} \mathrm{o} \mathrm{meio}$ de crescimento (com 10\% de soro fetal bovino) restituído, e as células incubadas de 48 a 72 hs. A expressão dos genes clonados, a partir dos plasmídios transfectados, foi constatada por ensaio de imunofluorescência como descrito no item 3.1.18. As proteínas recombinantes foram detectadas com o anticorpo policlonal anti-GMCTB (1:100) obtido em camundongo seguido do secundário anti-mouse conjugado com FITC (KPL), diluído a 1:50. Como controle da transfecção foi usado o plasmídio pIRES-EGFP $\left(\right.$ Clontech $\left.^{\circledR}\right)$, que contem o gene que codifica para a proteína EGFP (do inglês, enhanced green fluorescent protein). Essa proteína emite fluorescência quando a monocamada celular é iluminada com luz UV no microscópio de fluorescência invertido. A eficiência da transfecção foi estimada pelo percentual de células fluorescentes e essa condição padronizada foi utilizada para os demais plasmídeos (dados não apresentados).

\subsubsection{Esquemas de imunização}

\subsubsection{Imunizacão com proteína}

\subsection{Via intraperitoneal}

As proteínas CTB e GMCTB expressas em E. coli, e o peptídeo GM foram utilizados para imunização de camundongos Balb/C fêmeas de 6 a 8 semanas de idade, divididos em grupos de 5 animais. Foram administradas 4 doses da proteína, num volume de $100 \mu$, seguindo o esquema apresentado à figura 10. A primeira dose foi inoculada em CFA via subcutânea, e as restantes, por via intraperitoneal em IFA. Foram realizadas as seguintes condições: PBS, CTB $(26,8 \mu \mathrm{g}), \mathrm{GM}(10 \mu \mathrm{g}), \mathrm{CTB}+\mathrm{GM}(26,8 \mu \mathrm{g}$ e $10 \mu \mathrm{g}$, respectivamente), GMCTB $(40 \mu \mathrm{g})$. As coletas de sangue foram efetuadas por via retro-orbital no início do experimento (soro pré-imune) e 10 dias após a segunda, terceira e quarta doses. Para obter os soros o sangue foi coletado em tubos eppendorf e incubado por $30 \mathrm{~min}$ a $37{ }^{\circ} \mathrm{C}$, a seguir foi 
mantido a $4{ }^{0} \mathrm{C}$ por $1 \mathrm{~h}$ e centrifugado a $2.000 \mathrm{x}$ g por $10 \mathrm{~min}$. O sobrenadante (soro) foi transferido para um tubo novo, sendo estocado a $-20{ }^{0} \mathrm{C}$.

Figura 10- Esquema de ensaio de imunização intraperitoneal.

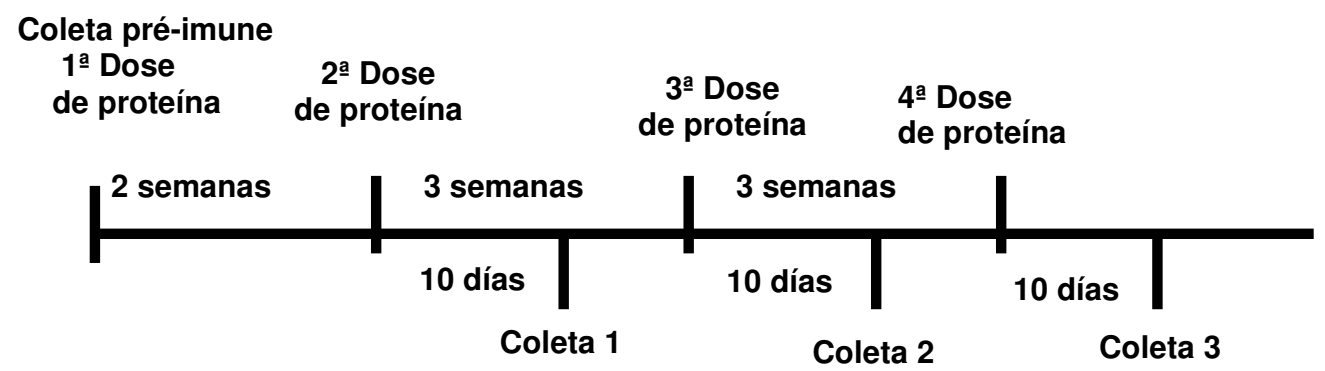

Na figura está indicado o intervalo entre as doses administradas e a realização das coletas de sangue.

Fonte: Medina-Armenteros (2012)

\subsection{Via intranasal}

As proteínas CTB e GMCTB expressas em E. coli, e o peptídeo GM foram utilizados para imunização de camundongos, seguindo o protocolo descrito por Arêas e colaboradores (Arêas et al., 2004). Camundongos Balb/C fêmeas de 6 a 8 semanas de idade foram divididos em grupos de 5 animais, sendo administradas 4 doses de proteína diluída em PBS (esquema à figura 11), num volume de 20-50 $\mu \mathrm{l}$, gotejados com micropipeta nas narinas dos animais. Foram realizadas as seguintes condições: PBS, CTB $(26,8 \mu \mathrm{g})$, GM $(10 \mu \mathrm{g})$, CTB + GM (26,8 $\mu \mathrm{g}$ e $10 \mu \mathrm{g}$, respectivamente), GMCTB (40 $\mu \mathrm{g}$ ). As coletas de sangue foram efetuadas como descrito no item anterior: no início do experimento (soro pré-imune) e 10 dias após a segunda, terceira e quarta doses. Após a última dose, também foi coletada a saliva dos animais aplicando $200 \mu \mathrm{L}$ de pilocarpina 0,02\%, intraperitonealmente. Após 1 min foram coletados aproximadamente $200 \mu \mathrm{L}$ de saliva usando micropipeta. 
Figura 11- Esquema de ensaio de imunização intranasal.

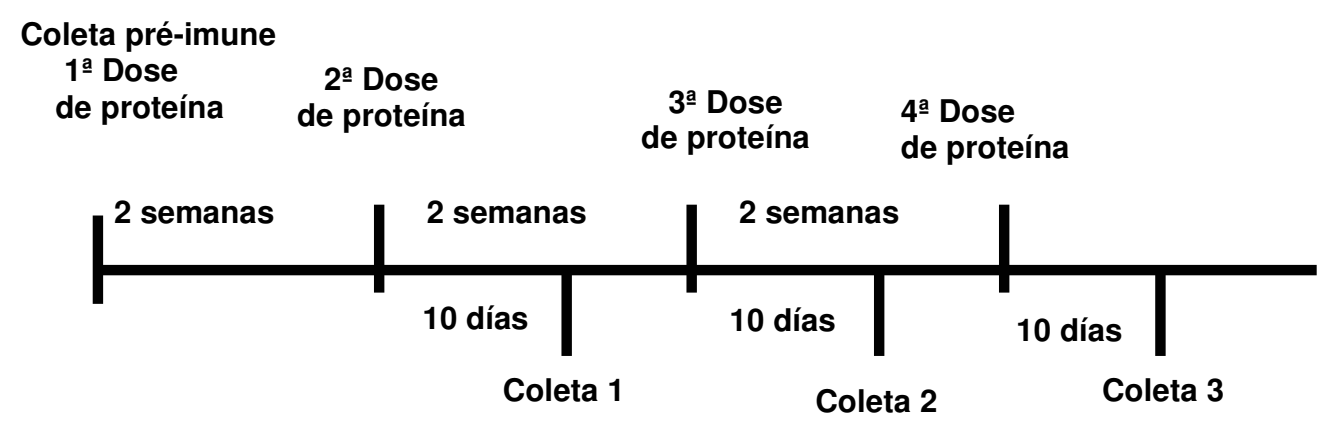

Na figura está indicado o intervalo entre as doses administradas e a realização das coletas de sangue e saliva.

Fonte: Medina-Armenteros (2012)

\subsubsection{Imunizaç̃o com vacinas de DNA}

Os plasmídios pTGM, pTCTB e pTGMCTB foram amplificados em grande escala (500$1000 \mathrm{~mL}$ de cultura de células DH5 $\alpha$ transformadas), e purificados por coluna de afinidade empregando o kit de purificação de plasmídios Qiagen Plasmid Mega Kit da QIAGEN ${ }^{\mathrm{TM}}$, conforme instruções do fabricante. Uma vez purificados, os plasmídeos foram utilizados para imunizar camundongos Balb/c de 6 a 8 semanas de idade. O DNA foi diluído em PBS até uma concentração de $0,4 \mu \mathrm{g} / \mu \mathrm{l}$, administrado junto com o adjuvante fosfato de alumínio, cuja concentração foi ajustada a $450 \mu \mathrm{g} / \mathrm{ml}$. Assim, em cada dose foram administrados $40 \mu \mathrm{g}$ de DNA junto com $45 \mu \mathrm{g}$ de fosfato de alumínio. As imunizações foram feitas via intramuscular, injetando-se $50 \mu \mathrm{l}$ da solução de DNA em cada perna traseira dos camundongos, na região do músculo quadríceps. Foram aplicadas 4 doses dos plasmídios como detalhado na figura 12 . O sangue dos animais foi coletado no início do experimento (coleta pré-imune) e 14 dias após a segunda, terceira e quarta doses (Lodmell et al., 2000). As coletas foram realizadas via retroorbital, como mencionado anteriormente. 
Figura 12- Esquema de imunização com DNA.

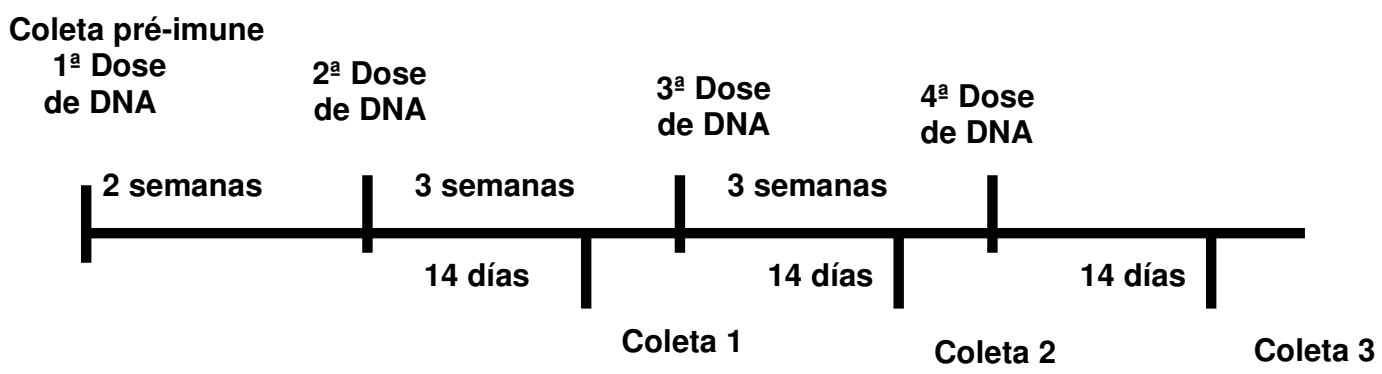

Na figura está indicado o intervalo entre as doses administradas e a realização das coletas de sangue.

Fonte: Medina-Armenteros (2012)

\subsubsection{ELISA}

Para testar a presença de anticorpos específicos nos soros obtidos nas imunizações dos animais de experimentação, utilizamos o ensaio de ELISA (Enzyme-Linked Immunosorbent assay) de captura de anticorpos. Para tanto, placas de PVC de 96 poços (NUNC ${ }^{\mathrm{TM}}$, Roskilde, Dinamarca) foram sensibilizadas mediante a adição de 50-200 ng/poço de proteína e incubação a $37{ }^{0} \mathrm{C}$ em atmosfera úmida, por $6 \mathrm{hs}$. Em seguida foram adicionados $300 \mu \mathrm{lde}$ tampão de bloqueio (PBS, Tween-20 0,05\%, BSA 1\%. As placas foram incubadas por $16 \mathrm{hs} \mathrm{a}$ $4{ }^{0} \mathrm{C}$, ON. Após esse tempo adicionaram-se $100 \mu \mathrm{l}$ dos soros diluídos em tampão de bloqueio, sendo que cada amostra foi testada nas diluições 1:100, 1:200, 1:400 e 1:800. As placas foram incubadas durante $1 \mathrm{~h}$ a $37{ }^{0} \mathrm{C}$ em atmosfera úmida e posteriormente foram lavadas 3 vezes com tampão de lavagem (PBS, Tween-20 0,05\%). Em seguida foi adicionado um anticorpo anti-IgG de camundongo conjugado a peroxidase (KPL) diluído 1:3.000 em tampão de bloqueio e as placas foram incubadas novamente a $37{ }^{0} \mathrm{C}$ em atmosfera úmida. A placa foi lavada 3 vezes com tampão de lavagem e adicionaram-se a cada poço $200 \mu \mathrm{L}$ de solução substrato (ácido cítrico 24,4 mM, $\mathrm{Na}_{2} \mathrm{HPO}_{4} 48,8 \mathrm{mM}$, OPD 0,8 mg/mL, $\mathrm{H}_{2} \mathrm{O}_{2}$ 0,045\%). As placas foram incubadas $10 \mathrm{~min}$ no escuro e posteriormente foram adicionados $25 \mu \mathrm{l}$ por poço de solução de $\mathrm{H}_{2} \mathrm{SO}_{4} 2 \mathrm{M}$ para parar a reação. Finalmente, mediu-se a absorbância de cada poço a $492 \mathrm{~nm}$. Para cada amostra de soro de animais foi realizada uma curva de diluição e os títulos de anticorpos foram determinados como o valor recíproco da última diluição que teve 
uma DO de 0,05. Para detectar a presença de anticorpos IgA na saliva dos animais imunizados por via intranasal, as amostras foram incubadas com um anticorpo anti-IgA de camundongo conjugado à peroxidase (SIGMA), diluído 1:1.000.

Nos gráficos são apresentadas as médias geométricas e seus respectivos desvios padrões das medidas, título de anticorpos ou absorbância. O título de anticorpos foi usado para os soros obtidos de animais imunizados com proteínas GM administradas via intraperitoneal, e a absorbância para o soro de animais imunizados com vacinas de DNA, bem como para o soro e a saliva de animais imunizados com proteínas GM via intranasal.

\subsubsection{Ensaio de neutralização}

Para a realização deste ensaio células HEp-2 foram semeadas em placas de 96 poços e cultivadas por 24 hs. Em paralelo, 1 MOI de HRSV A2 foi incubada com os soros de camundongos imunizados, diluídos em meio de infecção a 1:100, a $37{ }^{0} \mathrm{C}$ por $1 \mathrm{~h}$. Em seguida, as monocamadas de células HEp-2, com aproximadamente $70 \%$ de confluência, foram infectadas. Para isso, o meio de crescimento foi retirado, foram adicionados $100 \mu \mathrm{L}$ por poço das suspensões de HRSV pré-tratados e a placa foi incubada por $2 \mathrm{hs}$. Finalizado este período, o meio foi restituído a $200 \mu \mathrm{L}$ e as células foram incubadas por $48 \mathrm{hs}$. Todos os tratamentos foram realizados em meio de infecção. As células foram observadas às 48 hs após infecção verificando a presença do efeito citopático caraterístico de formação de sincícios.

\subsubsection{Desafio}

Quatorze dias após a última imunização os camundongos foram infectados com 20$50 \mu \mathrm{L}$ da cepa de desafio HRSV A2 $\left(1 \times 10^{8} \mathrm{UFS} / \mathrm{mL}\right.$, em PBSS) pela via intranasal, seguindo um protocolo similar ao empregado por Arêas e colaboradores (Arêas et al., 2004). Cinco dias após infecção os animais foram sacrificados e os pulmões foram coletados em condições assépticas. Um deles foi utilizado para realizar extração de RNA e posterior quantificação por PCR em tempo real, e o outro, para análise histopatológica. 


\subsubsection{Real time qPCR}

\subsubsection{Extracão de RNA}

Os pulmões de animais desafiados foram colocados em tubos Falcon, pesados e em seguida colocados em Trizol (Invitrogen ${ }^{\mathrm{TM}}$ ) a uma proporção de $1 \mathrm{~mL}$ por $100 \mathrm{mg}$ de tecido. $\mathrm{O}$ RNA com Trizol foi macerado após congelamento em nitrogênio líquido. A suspensão foi transferida a tubos eppendorf de $1,5 \mathrm{~mL}$, centrifugada a $12.000 \mathrm{x} \mathrm{g} \mathrm{a} 4{ }^{0} \mathrm{C}$ por $10 \mathrm{~min}$ e o sobrenadante foi coletado e transferido a um tubo novo. Foram acrescentados $200 \mu \mathrm{L}$ de clorofórmio por $750 \mu \mathrm{L}$ de Trizol, agitado vigorosamente em Vortex, e centrifugado a 12.000 x g a $4{ }^{0} \mathrm{C}$ por $10 \mathrm{~min}$. A fase aquosa foi coletada e o RNA foi precipitado pela adição de 500 $\mu \mathrm{L}$ de isopropanol. Após incubação a TA por 10 min e centrifugação a 12.000 x g a $4{ }^{0} \mathrm{C}$ por 10 min, o precipitado obtido foi lavado com etanol $75 \%$ e novamente centrifugado. $\mathrm{O}$ precipitado final foi ressuspendido em água DEPC, quantificado por medida de absorbância a 260nm e estocado a $-70{ }^{0} \mathrm{C}$.

\subsubsection{Síntese de cDNA}

Para a obtenção do cDNA, $1 \mu \mathrm{g}$ do RNA extraído de pulmão foi tratado com $1 \mathrm{U}$ de DNase I no tampão de reação $1 \mathrm{X}$, num volume final de $10 \mu \mathrm{L}$, conforme o protocolo do kit DNase I amplification grade da Invitrogen ${ }^{\mathrm{TM}}$. Após incubação a TA por 15 min, foi acrescentado EDTA a uma concentração final de $2 \mu \mathrm{M}$ e a enzima foi inativada a $65{ }^{0} \mathrm{C}$ por 10 min. Com o RNA tratado, o cDNA foi obtido utilizando o kit SuperScript III Reverse transcriptase da Invitrogen ${ }^{\mathrm{TM}}$. Foi preparada uma primeira mistura da reação com $1 \mu 1$ de random primers $50 \mathrm{ng} / \mu \mathrm{L}, 1 \mu \mathrm{L}$ de dNTPs $10 \mathrm{mM}, 500 \mathrm{ng}$ do RNA previamente tratado e água DEPC até completar $14 \mu \mathrm{L}$, que foi incubada a $65{ }^{0} \mathrm{C}$ por $5 \mathrm{~min}$, e logo após colocada no gelo por 2 min. Em paralelo, foi preparada uma segunda mistura de reação com $4 \mu \mathrm{L}$ de tampão de reação da $\mathrm{RT} 5 \mathrm{X}, 1 \mu \mathrm{L}$ de $0,1 \mathrm{M}$ de ditiotreitol e $1 \mu \mathrm{L}$ da enzima transcriptase reversa 200U/ $\mu \mathrm{L}$. Os $6 \mu \mathrm{L}$ desta segunda mistura foram adicionados à primeira mistura (volume final de $20 \mu \mathrm{L}$ ). A reação final foi incubada a $25{ }^{0} \mathrm{C}$ por 5 min e $\log$ o após, a $50{ }^{0} \mathrm{C}$ por $50 \mathrm{~min}$. Terminada a reação, os tubos foram resfriados a $4{ }^{0} \mathrm{C}$, e o cDNA obtido foi estocado a $-20{ }^{0} \mathrm{C}$. Todas as reações foram realizadas em tubos eppendorf de $200 \mu \mathrm{L}$. 


\subsubsection{Reacão de real time qPCR}

O RNA foi testado pelo método de quantificação absoluta usando o protocolo de amplificação com SYBR Green da Applied Biosystems. Brevemente, $1 \mu 1$ da reação de cDNA foi colocado na mistura da reação contendo $12,5 \mu \mathrm{L}$ de power SYBR Green PCR, 0,2 $\mu \mathrm{M}$ de cada oligonucleotídeo e água até completar os $25 \mu \mathrm{L}$ do volume total da reação. Foram usados os oligonucleotídeos NF e NR descritos no item 3.1.5 para amplificar uma seqüência de 194 pb do gene N do HRSV. A reação de PCR foi desenvolvida no sistema de detecção Applied Biosystem 7500 SDS, em tubos ópticos MicroAmp da Applied Biosystems, sofrendo a repetição de 40 ciclos de $95{ }^{\circ} \mathrm{C}$ por $15 \mathrm{seg}$ e $60{ }^{\circ} \mathrm{C}$ por $1 \mathrm{~min}$.

\subsubsection{Análise histopatológica}

Cinco dias após infecção com o HRSV os animais foram sacrificados e um dos pulmões de cada animal foi colocado em cassete de emblocamento, e fixado em paraformaldeido $4 \%$ a $4{ }^{0} \mathrm{C}$ por $24 \mathrm{hs}$. Após esse tempo o tecido fixado foi mantido em etanol $70 \%$. Os pulmões foram embebidos em parafina, e nos blocos obtidos foram feitos 3 cortes seqüenciais utilizando micrótomo. Os 3 cortes foram fixados em lâminas e corados com eosina e hematoxilina. Na observação ao microscópio, foi analisada a presença das lesões relacionadas na tabela 2, bem como a sua intensidade, estabelecendo um escore de 0 a 3 como aparece embaixo da tabela. Foi calculado um escore de histopatologia geral para cada amostra, obtido como resultado da somatória do escore individual para cada lesão.

Tabela 2-. Escore das lesões.

\begin{tabular}{|c|c|}
\hline Tipo de lesão/tipos celulares presentes & Intensidade $(0 \text { a } 3)^{*}$ \\
\hline \multicolumn{2}{|l|}{ Pneumonia } \\
\hline \multicolumn{2}{|l|}{ Hiperplasia linfóide } \\
\hline \multicolumn{2}{|l|}{ Linfócitos } \\
\hline \multicolumn{2}{|l|}{ Macrófagos } \\
\hline Eosinófilos & \\
\hline
\end{tabular}

$* 0=$ ausente $; 1=$ discreta; $2=$ moderada; $3=$ intensa

Fonte: Medina-Armenteros (2012) 


\section{RESULTADOS}

\subsection{Obtenção dos estoques de HRSV}

Para desenvolver os objetivos propostos neste projeto, o primeiro passo foi a preparação dos estoques virais a serem usados nos experimentos de infecção e desafio. A cepa A2 de HRSV foi multiplicada em células HEp-2 e titulada por imunofluorescência conforme descrito no item 3.1.18. Aproximadamente 40 hs após infecção, as células inoculadas com vírus apresentaram um efeito citopático característico com formação de sincícios. Elas foram coletadas, o vírus foi concentrado por ultracentrifugação (item 3.2.1), e a sua presença foi detectada por imunofluorescência. A figura 13 mostra o resultado da infecção com o estoque

Figura 13- Imunofluorescência de células HEp-2 infectadas.

FITC

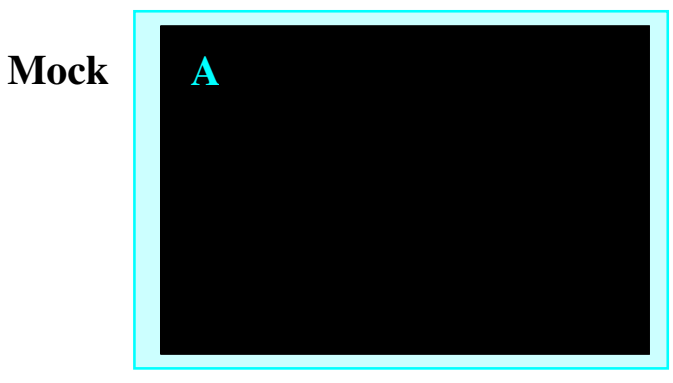

HRSV

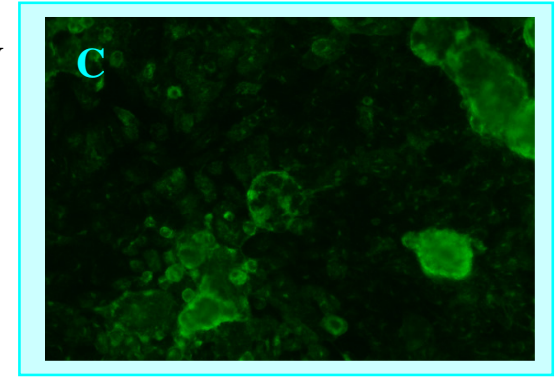

FITC+DAPI
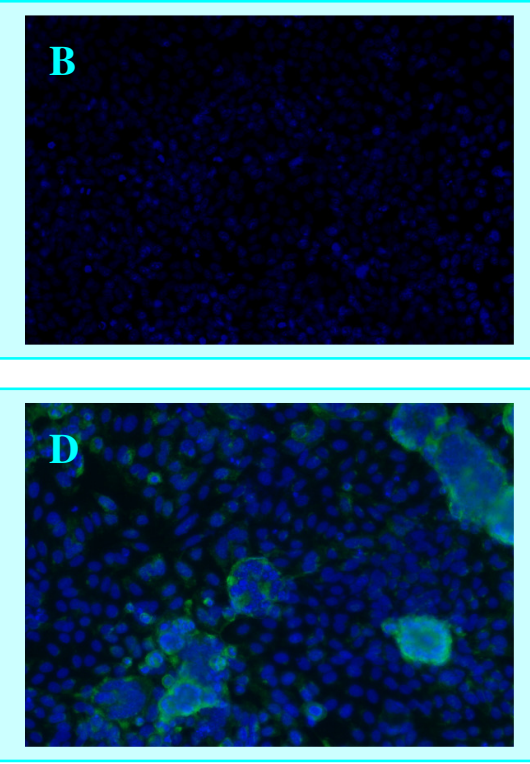

Panéis A e B células sem infectar, C e D células infectadas com HRSV (MOI 1). O anticorpo anti-G utilizado foi o monoclonal C793. Painéis A e C células coradas com anti-IgG conjugado com FITC; painéis B e D coloração com FITC e DAPI. Aumento 200X.

Fonte: Medina-Armenteros (2012) 
viral diluído a $10^{-7}$, observando-se células gigantes multinucleadas (núcleos corados em azul com DAPI), apresentando fluorescência verde correspondente à detecção da proteína G viral, mais intensa nas bordas, congruente com a sua localização na membrana celular. Neste caso o título do estoque viral foi estimado em $1 \times 10^{8} \mathrm{UFS} / \mathrm{mL}$ e o vírus usado como inóculo nos ensaios de infecção e desafio.

\subsection{Seleção de epítopos por predição}

A utilização dos programas SYFPEITHI e PRED ${ }^{\text {BALB/C }}$ permitiu selecionar 9 seqüências aminoácidicas distribuídas ao longo da proteína L (figura 14) que contem prediptopes de 9-mer com alto escore de ligação às moléculas de MHC-I H-2D ${ }^{\mathrm{d}}, \mathrm{K}^{\mathrm{d}}$ e $\mathrm{L}^{\mathrm{d}}$ (escore $>9$ numa faixa de 1-10 para PRED ${ }^{\mathrm{BALB} / \mathrm{C}}$, e $>20$ para SYFPEITHI numa faixa de 130). Foi escolhido o haplótipo de Balb/c sendo que essa é a linhagem que mimetiza melhor a doença exacerbada acarretada pela vacina em humanos. As sequiências selecionadas são apresentadas na tabela 3 .

Como pode ser observado na figura 14, das 9 seqüências peptídicas, apenas 3 estão contidas nos domínios preditos para a proteína L: S5 encontra-se no domínio III identificado como o módulo de polimerização que contem o sítio ativo; S8, no domínio IV provavelmente envolvido em poliadenilação; e S9, no domínio V responsável pela adição do CAP ao mRNA (Stec et al., 1991; Liuzzi et al., 2005).

Figura 14- Esquema da distribuição das seqüências selecionadas na proteína L.

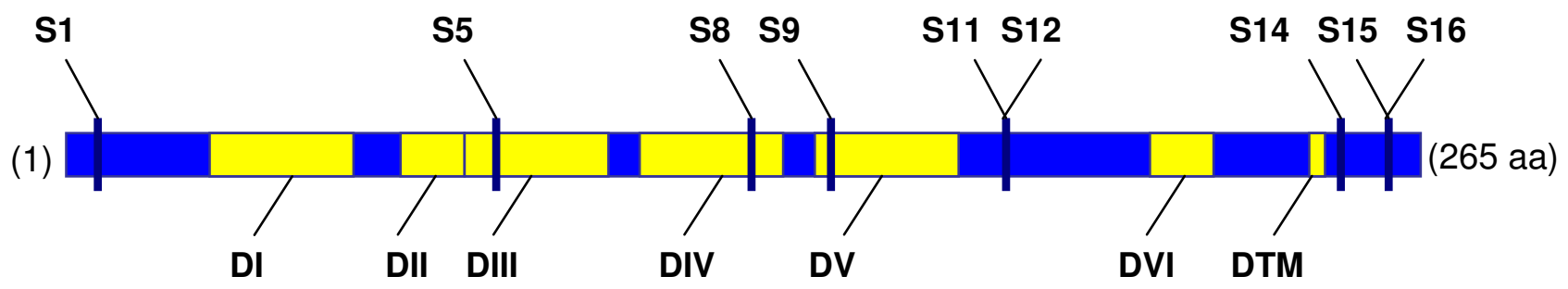

Representação dos domínios (D) funcionais e o domínio transmembrana (DTM) preditos por meio de estudos comparativos com outras polimerases, incluindo a do vírus Sendai que como o RSV pertence à família Paramixoviridae (Stec et al., 1991; Carromeu, 2007).

Fonte: Medina-Armenteros (2012) 
Tabela 3- Peptídeos da proteína L selecionados.

\begin{tabular}{|c|c|c|c|c|}
\hline Peptídeos & Posição & $\begin{array}{l}\text { Seqüiência de } \\
\text { aminoácidos }\end{array}$ & Prediptopes & $\begin{array}{l}\text { Restrição } \\
\text { do MHC-I }\end{array}$ \\
\hline \multirow[t]{3}{*}{ S1 } & $31-48$ & LGSYIFNGPYLKNDYTNL & GSYIFNGPY & $D^{d}$ \\
\hline & & & SYIFNGPYL & $\mathrm{D}^{\mathrm{d}}, \mathrm{K}^{\mathrm{d}}$ \\
\hline & & & NGPYLKNDY & $\mathrm{D}^{\mathrm{d}}$ \\
\hline \multirow[t]{2}{*}{ S5 } & $744-753$ & CTYRHAPPYI & CTYRHAPPY & $\mathrm{D}^{\mathrm{d}}$ \\
\hline & & & TYRHAPPYI & $\mathrm{D}^{\mathrm{d}}, \mathrm{K}^{\mathrm{d}}$ \\
\hline \multirow[t]{3}{*}{ S8 } & $1114-1129$ & IEPTYPHGLRVVYESL & IEPTYPHGL & $\mathrm{D}^{\mathrm{d}}$ \\
\hline & & & TYPHGLRVV & $\mathrm{D}^{\mathrm{d}}, \mathrm{K}^{\mathrm{d}}$ \\
\hline & & & GLRVVYESL & $\mathrm{K}^{\mathrm{d}}$ \\
\hline S9 & $1224-1238$ & IMYTMDIKYTTSTIS & IMYTMDIKY & $\mathrm{D}^{\mathrm{d}}$ \\
\hline \multirow[t]{2}{*}{ S11 } & $1513-1531$ & IFEKDWGEGYITDHMFINL & EGYITDHMF & $\mathrm{D}^{\mathrm{d}}$ \\
\hline & & & GYITDHMFI & $\mathrm{D}^{\mathrm{d}}, \mathrm{K}^{\mathrm{d}}$ \\
\hline \multirow[t]{3}{*}{ S12 } & $1530-1545$ & NLKVFFNAYKTYLLCF & VFFNAYKTY & $\mathrm{K}^{\mathrm{d}}$ \\
\hline & & & FFNAYKTYL & $\mathrm{D}^{\mathrm{d}}, \mathrm{K}^{\mathrm{d}}$ \\
\hline & & & AYKTYLLCF & $\mathrm{D}^{\mathrm{d}}$ \\
\hline S14 & $2059-2067$ & CYPITKKGI & CYPITKKGI & $D^{d}, K^{d}$ \\
\hline S15 & $2113-2121$ & VLNFRSTEL & VLNFRSTEL & $\mathrm{K}^{\mathrm{d}}$ \\
\hline \multirow[t]{3}{*}{ S16 } & $2125-2140$ & HLYMVESTYPYLSELL & HLYMVESTY & $\mathrm{D}^{\mathrm{d}}$ \\
\hline & & & STYPYLSEL & $\mathrm{D}^{\mathrm{d}}$ \\
\hline & & & TYPYLSELL & $\mathrm{D}^{\mathrm{d}}, \mathrm{K}^{\mathrm{d}}$ \\
\hline
\end{tabular}

Fonte: Medina-Armenteros (2012)

4.3 Análise da resposta imune celular contra os peptídeos da proteína $L$

\subsubsection{Resposta imune celular contra L imunizando com peptídeos}

Para testar a reposta imune celular contra os peptídeos selecionados (S1, S5, S8, S9, S11, S12, S14, S15 e S16) camundongos Balb/c foram imunizados segundo o esquema detalhado à figura 9 no item 3.2.3.1. Oito dias após a quarta imunização com peptídeos, foram coletados os baços dos camundongos e obtidas culturas primárias de linfócitos para testar a 
resposta de liberação de IFN- $\gamma$ por meio do ensaio ELISPOT. Os resultados são mostrados na figura 15.

Figura 15- Resposta de liberação de IFN- $\gamma$ após imunização com peptídeos.

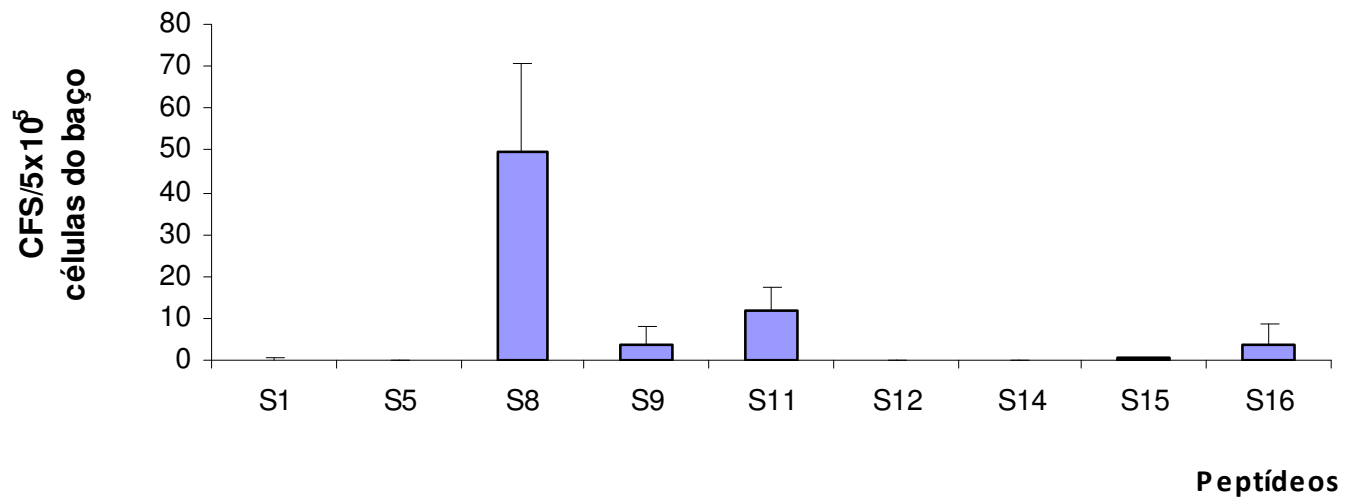

Está apresentado o resultado de ELISPOT em camundongos Balb/c após imunização com os peptídeos selecionados. Foram administradas 4 doses dos peptídeos indicados a cada grupo de animais. As células do baço foram coletadas 7 dias após a última dose e estimuladas ex vivo com 250 ng do peptídeo homólogo. Os resultados estão expressos como a média geométrica (com o desvio padrão) do valor de células formadoras de spots (CFS) por $5 \times 10^{5}$ células do baço para cada grupo ( $\mathrm{n}=5$ animais). Um grupo controle foi imunizado apenas com PBS.

Fonte: Medina-Armenteros (2012)

Células do baço dos animais imunizados com S8, S9, S11 e S16 secretaram IFN- $\gamma$ quando cultivadas ex vivo com os mesmos peptídeos, com valores de 49, 4, 12, e 4 células formadoras de spots (CFS), respectivamente. Essa resposta foi específica sendo que o número de spots gerado pelas células procedentes de animais inoculados com PBS e estimuladas com os peptídeos selecionados ex vivo foi 0 (dados não mostrados). Por outro lado os demais peptídeos não foram capazes de estimular a liberação de IFN- $\gamma$.

\subsubsection{Resposta imune celular no contexto da infecção viral}

Para verificar a replicação viral no pulmão dos camundongos Balb/c infectados, foram administradas duas doses de vírus purificado a intervalos de 9 ou 10 dias, e foi medido o peso dos animais diariamente, desde o primeiro dia após a primeira dose, até o décimo dia após a segunda dose. A perda de peso tem sido reportada como um indicador da replicação viral embora não exista um correlato total. No nosso caso não foi observada diminuição do peso dos 
camundongos infectados, comparado ao peso dos animais inoculados apenas com PBSS (dados não apresentados). No entanto, foi comprovada a infecção viral pela detecção da proteína $M$ de HRSV por Western Blot (figura 16) a partir do vírus isolado do pulmão de camundongos no quinto dia após a infecção viral, sendo que o pico máximo de replicação viral está entre o quarto e o quinto dia.

$\mathrm{Na}$ canaleta 2 da figura 16, correspondente ao vírus isolado a partir do pulmão dos animais infectados com HRSV diluído 1:10, aparece uma banda entre as bandas de 26 e 34kDa do marcador de massa molecular que também é observada no controle positivo, porém ausente na amostra obtida do pulmão de camundongos imunizados apenas com PBSS e do isolado diluído 1:100. Esta banda indica a presença da proteína M ( 33kDa) e a replicação do HRSV no pulmão. A não detecção da proteína $M$ na amostra do isolado 1:100 (canaleta 3) pode se dever ao fato dela estar mais diluída. As bandas observadas apresentam uma migração diferente. Isto pode ser devido à diferença de densidade entre as amostras provenientes de tecido de pulmão (canaletas 1, 2, e 3) e de cultura de células (canaleta 4).

Figura 16- Análise da replicação viral por Western Blot.

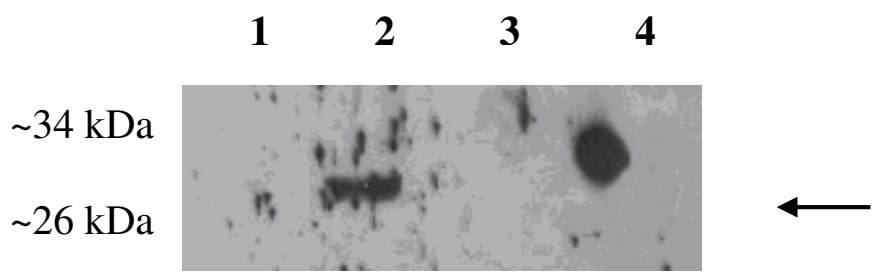

A proteína $\mathrm{M}$ foi detectada no homogenato de pulmão de camundongos infectados com HRSV. Amostra 1: homogenato de pulmão de animais inoculados com PBSS, diluição 1:10; amostras 2 e 3: homogenato de pulmão (diluição 1:10 e 1:100, respectivamente) de animais infectados com HRSV; amostra 4: vírus purificado a partir de células HEp-2 (controle positivo).

Fonte: Medina-Armenteros (2012)

Num primeiro experimento para determinar a resposta imune celular foram administradas duas doses de vírus purificado de $2 \times 10^{5}$ UFS/animal a um intervalo de 9 dias e, num segundo experimento, duas doses de $2 \times 10^{6}$ UFS/animal, separadas por 8 dias. Dez ou doze dias após a última dose, respectivamente, foram coletados baço e pulmão, obtidas culturas primárias de linfócitos e analisada a resposta de liberação de IFN- $\gamma$ para o baço (figura 17) e para o pulmão 
Figura 17- Resposta de liberação de IFN- $\gamma$ no baço.

a)

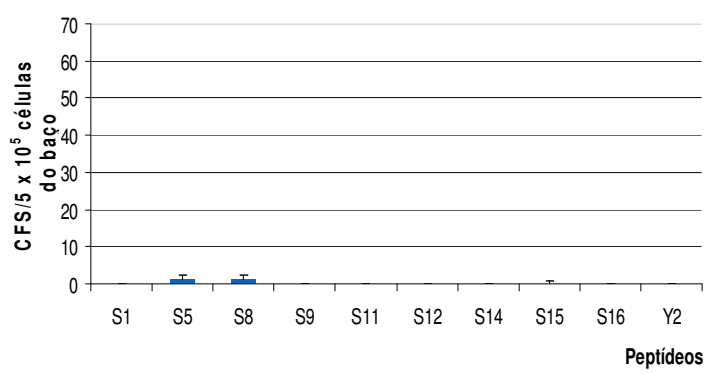

c)

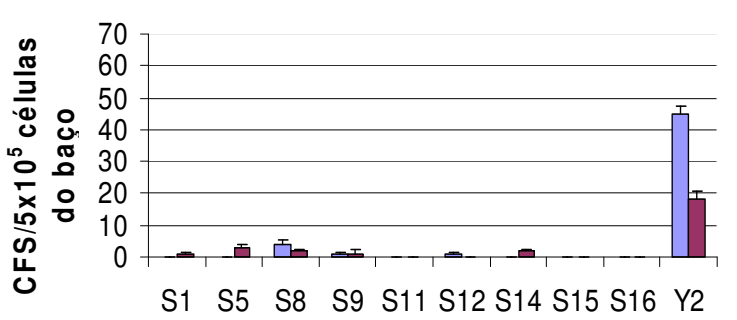

Peptídeos b)

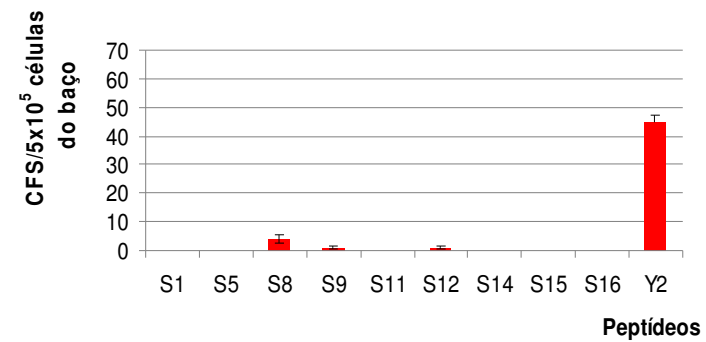

d)

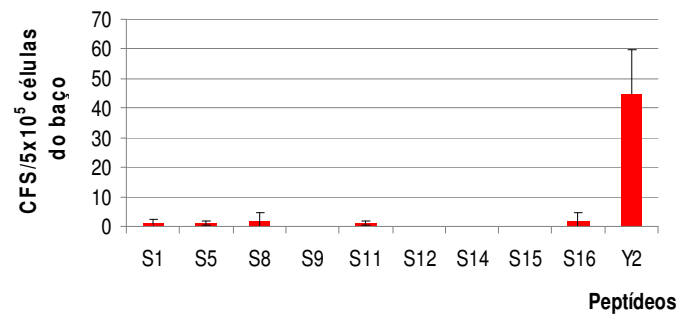

$\square \quad$ - anti CD8

$\square$ + anti CD8

O resultado está expresso como a média geométrica entre duplicatas de CFS específicos de linfócitos do baço de um pool de animais inoculados com PBSS (painel a); infectados com $2 \times 10^{5}$ e $2 \times 10^{6}$ UFS/animal de HRSV por via intranasal (painéis b e d, respectivamente). O painel c mostra a resposta de IFN- $\gamma$ por linfócitos do baço de camundongos infectados com $2 \times 10^{5}$ UFS na presença ou ausência do anticorpo anti-CD8.

Fonte: Medina-Armenteros (2012)

(figura 18), mediante estímulo com peptídeos da proteína L (tabela 3) num ensaio ELISPOT. Como controle positivo foi usado o peptídeo $M 2_{82-90}$ da segunda proteína de matriz que constitui o epítopo de células TCD8+ imunodominante na infecção por HRSV restrito para $\mathrm{H}-2 \mathrm{~K}^{\mathrm{d}}$, denominado como Y2. Nos animais infectados com HRSV observa-se que a estimulação com o peptídeo S8 teve uma frequiência de linfócitos do baço respondedores à 
liberação de IFN- $\gamma$ de 4 (painel b) e 2 (painel d) CFS; também apresentaram resposta os peptídeos S9 e S12. De forma geral essa resposta foi baixa comparada com o número de células secretoras de IFN- $\gamma$ estimuladas pelo peptídeo Y2, de aproximadamente 40 CFS em

Figura 18- Resposta de liberação de IFN- $\gamma$ nos pulmões.

a)

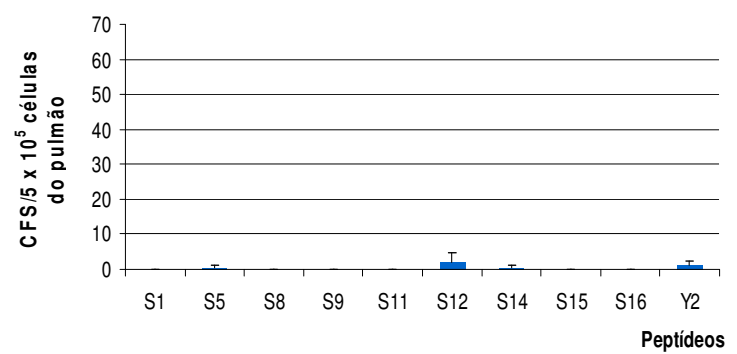

c)

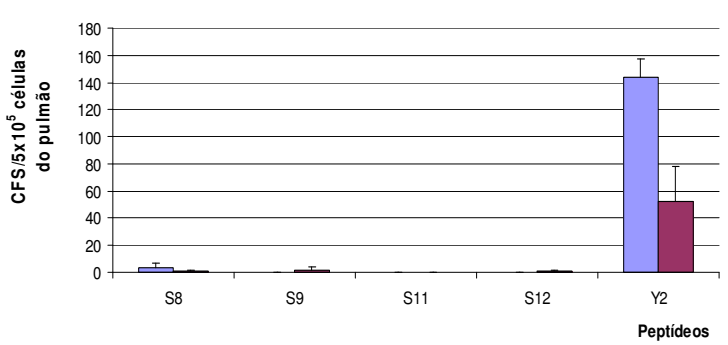

- anti CD8

+ anti CD8 b)

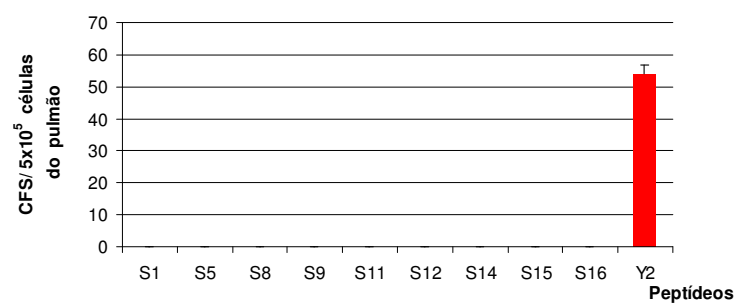

d)

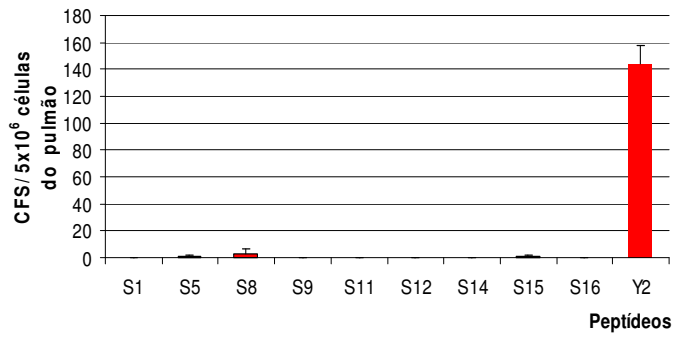

O resultado está expresso como a média geométrica entre duplicatas de CFS específicos de linfócitos pulmonares de um pool de animais inoculados com PBSS (painel a); infectados com 2 $\times 10^{5}$ e $2 \times 10^{6}$ UFS/animal de HRSV por via intranasal (panéis b e d, respectivamente). O painel c mostra a resposta de IFN- $\gamma$ por linfócitos pulmonares de camundongos infectados com $2 \times 10^{6}$ UFS na presença ou ausência do anticorpo anti-CD8.

Fonte: Medina-Armenteros (2012) 
ambos experimentos. Também não foi observado um aumento do número de spots com o aumento da dose de vírus para o peptídeo controle (painéis b e d).

A resposta de linfócitos pulmonares frente aos peptídeos foi similar à resposta dos linfócitos do baço (ver figura 18): apenas foram ativadas células T secretoras de IFN- $\gamma$ quando as células do pulmão de animais infectados foram estimuladas com o peptídeo S8, com um valor de 3 CFS. Os peptídeos S5 e S15 também foram capazes de gerar uma baixa resposta de células $\mathrm{T}$ respondedoras (painel d) comparado com o controle positivo $\mathrm{Y} 2$. Diferente da resposta mostrada pelas células do baço, a estimulação de CFS por linfócitos pulmonares parece que está influenciada pela dose de vírus utilizada. Observam-se valores 3 vezes maiores de CFS frente à estimulação com o peptídeo Y2: 54 CFS (painel b, 2x10 UFS) e 144 CFS (painel d, 2x10 6 UFS). Além disso, não foi observada resposta frente à ativação com os peptídeos analisados de células provenientes de animais infectados com a dose menor, enquanto houve uma pequena resposta com a dose maior para 3 peptídeos (S5, S8 e S15).

Tanto na resposta das células do baço quanto na do pulmão a adição de um anticorpo anti-CD8 diminuiu o número de CFS. No baço (figura 17, painel c) foi observada uma diminuição de $60 \%$ e $50 \%$ para Y2 e S8, enquanto no pulmão (figura 18, painel c) foi de $63.9 \%$ e $66.7 \%$, respectivamente. Esses resultados indicam que células TCD8+ são responsáveis por uma parte da resposta celular induzida por esses peptídeos, sugerindo que as mesmas contêm epítopos de células T CD8+.

Baseado nos resultados apresentados às figuras 17 e 18, foram escolhidos os peptídeos S8, S9, S11, S12 para serem aplicados em ensaios de imunização de camundongos Balb/c. Oito dias após a quarta imunização com os peptídeos, foram coletados os baços dos camundongos e obtidas culturas primárias de linfócitos para testar a resposta de liberação de IFN- $\gamma$ por meio dos ensaios ELISPOT e marcação intracelular de citocinas. Células do baço dos animais imunizados com S8 e S11 secretaram IFN- $\gamma$ quando cultivadas ex vivo com os peptídeos correspondentes com valores de 2 e 7 CFS, respectivamente (figura 19, painel b), enquanto o peptídeo controle Y2 mostrou um valor de 17 CFS. Além disso, a resposta foi específica sendo que o número de spots mostrado pelas células procedentes de animais inoculados com PBS e estimuladas ex vivo foi nulo (figura 19, painel a). A resposta de CFS frente aos peptídeos S8, S11 e Y2 quando presente o anti-CD8 foi reduzida em 50\%, 85,7\% e $64,7 \%$, respectivamente. Esse resultado reforça o dado de que as sequiências em teste contêm 
Figura 19- Resposta de IFN- $\gamma$ nos ensaios ELISPOT e ICS, após imunização com os peptídeos escolhidos.

a)

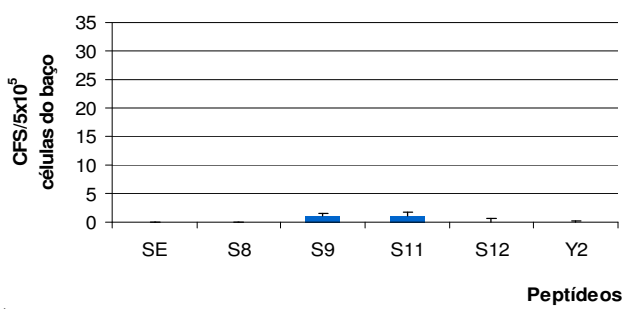

c)

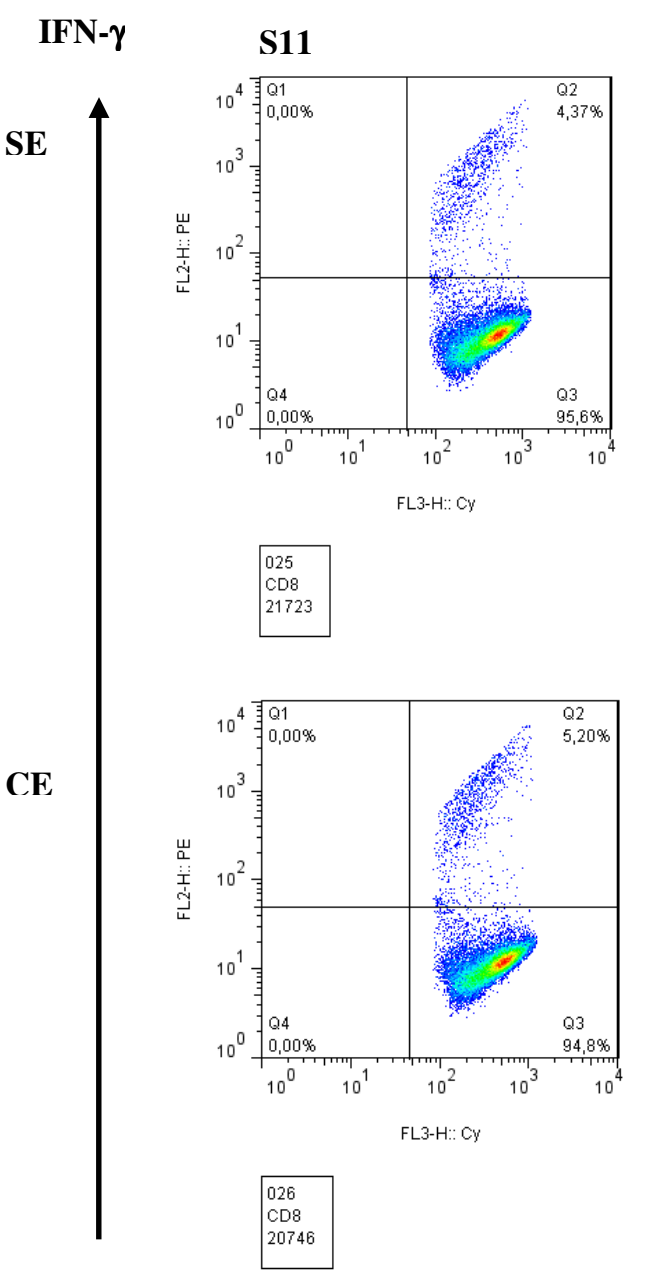

b)

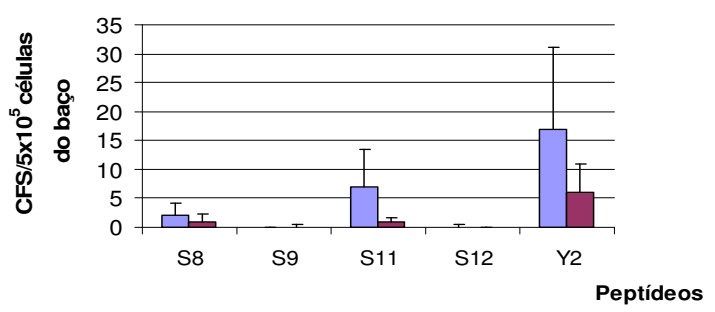

Y2

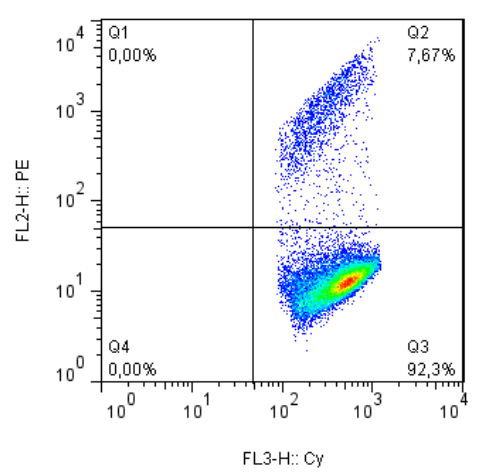

032
$\mathrm{CD} 8$ CD8
22236

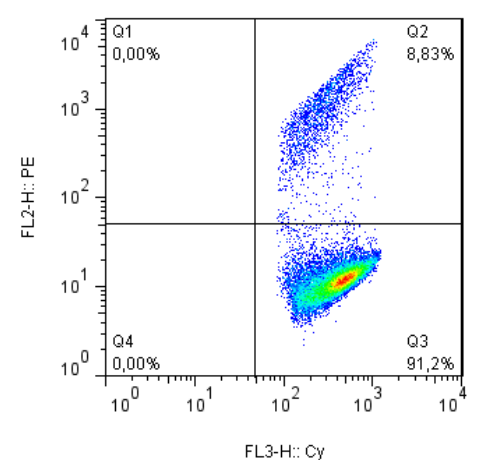

031
$\mathrm{CD} 8$

20034

CD8+

Está apresentada a resposta de liberação de IFN- $\gamma$ no ensaio ELISPOT de linfócitos do baço de animais inoculados com PBS (painel a), ou imunizados com peptídeos (painel b). Os resultados estão expressos como a média geométrica de CFS específicos para cada grupo ( $\mathrm{n}=3$ animais). $\mathrm{O}$ painel $\mathbf{c}$ mostra a citometria de fluxo de linfócitos TCD8+ secretores de IFN- $\gamma$ do baço de animais imunizados com os peptídeos S11 e Y2 estimulados com o peptídeo homólogo (CE) ex vivo, e sem estimular (SE). $\mathrm{O}$ número no quadrante superior à direita de cada dot plot indica a porcentagem de células CD8+ secretoras de IFN- $\gamma$.

Fonte: Medina-Armenteros (2012) 
epítopos de células T CD8+, como observado na resposta de liberação de IFN- $\gamma$ na infecção viral.

A resposta de CFS foi baixa para o controle positivo, bem como para os peptídeos S8 e S11, comparado com os resultados anteriores de resposta de CFS quando administrados como peptídeos (figura 15), devido, provavelmente, a problemas da técnica. Contudo, os resultados obtidos coincidem com o constatado na infecção viral (figuras 17 e 18) onde se destacou o peptídeo S8, e também quando os peptídeos foram usados como imunógenos (figura 15), onde S8 e S11 apresentaram valores de 49 e 12 CFS /5 x $10^{5}$ células do baço, respectivamente. A análise da liberação de IFN- $\gamma$ por células do baço reestimuladas ex vivo, por ensaio de marcação de citocina e citometria de fluxo (figura 19, painel c) revelou uma freqüência de células T CD8+ secretoras de IFN- $\gamma$ 0,83\% maior quando estimuladas com $\mathrm{S} 11$ que sem estimular. O controle Y2 mostrou um valor de 1,16\% e o resto dos peptídeos testados não apresentou diferenças (não apresentado).

Dos 9 peptídeos selecionados, apenas S8 e S11 apresentam epítopos responsivos às células $\mathrm{T}$ de maneira considerável. $\mathrm{O}$ alinhamento das seqüências da proteína $\mathrm{L}$ das cepas analisadas permitiu constatar que esses peptídeos apresentam 100\% de homologia, portanto, são altamente conservados e estão presentes nos 2 subgrupos de HRSV (A e B). Outro aspecto a salientar é o fato de que a administração das sequiências como vacina de peptídeo (figura 15) foi capaz de gerar uma resposta de células $\mathrm{T}$ efetoras, medida pela liberação de IFN- $\gamma$ no ELISPOT, maior que quando eles são apresentados ao sistema imune no contexto da infecção viral (figuras 17 e 18). S8 e S11 apresentaram valores altos de CFS (figura 15), além disso vale salientar que S11 apresentou valores de células secretoras de IFN$\gamma$ apenas 2,5 vezes menor que o peptídeo imunodominante M2 $2_{82-90}$ (Y2 na figura 19, painel b).

A molécula de MHC-I liga peptídeos de 8-15 aa numa única fenda, porém a maioria dos peptídeos que se ligam a esta molécula é de 9 aa (Rammensee et al., 1993). Dentro de S8 (16 aa) e S11 (19aa) temos prediptopes de 9-mer que apresentaram alto escore de ligação ao MHC-I do haplótipo H-2 ${ }^{\text {d }}$ (tabela 4). Esses peptídeos de 9 aa foram utilizados em ensaios de imunização de camundongos Balb/c conforme descrito no item 3.2.3.1, e as células do baço foram submetidas a ensaio ELISPOT (ver item 3.2.3.5.1). 
Tabela 4- Peptídeos de 9-mer dentro das sequiências selecionadas.

\begin{tabular}{llll}
\hline Peptídeos & $\begin{array}{l}\text { Seqüência de } \\
\text { aminoácidos }\end{array}$ & Prediptopes & $\begin{array}{l}\text { Restrição } \\
\text { do MHC-I }\end{array}$ \\
\hline S8 & IEPTYPHGLRVVYESL & S8.1 IEPTYPHGL & $\mathrm{D}^{\mathrm{d}}$ \\
& & S8.2 TYPHGLRVV & $\mathrm{D}^{\mathrm{d}}, \mathrm{K}^{\mathrm{d}}$ \\
& & S8.3 GLRVVYESL & $\mathrm{K}^{\mathrm{d}}$ \\
S11 & IFEKDWGEGYITDHMFINL & S11.1 EGYITDHMF & $\mathrm{D}^{\mathrm{d}}$ \\
& & S11.2 GYITDHMFI & $\mathrm{D}^{\mathrm{d}}, \mathrm{k}^{\mathrm{d}}$ \\
\hline
\end{tabular}

Fonte: Medina-Armenteros (2012)

A figura 20 mostra o número de spots produzido pelos prediptopes de 9 aa. Os linfócitos de animais imunizados com S8.2 e S11.2 apresentaram uma resposta mínima de formação de spots (1 e 2 CFS, respectivamente), quando estimulados com o peptídeo homólogo.

Figura 20- Resposta de liberação de IFN- $\gamma$ após imunização com peptídeos de 9-mer.

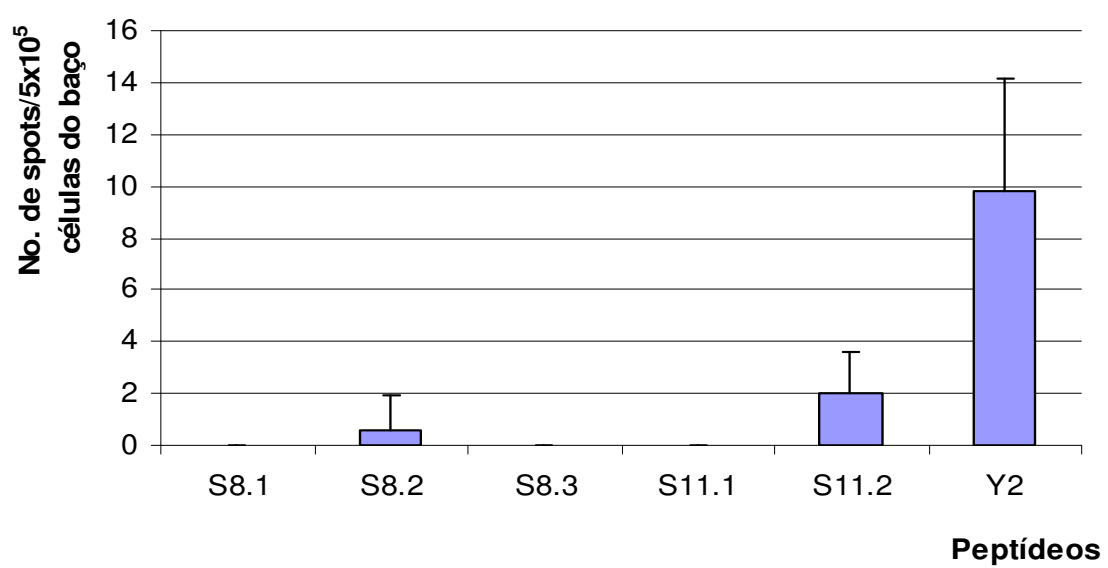

Está apresentado ensaio ELISPOT de camundongos Balb/c após administração de 4 doses do mesmo peptídeo em cada grupo. As células do baço foram coletadas 7 dias após a última dose, e estimuladas ex vivo com $250 \mathrm{ng}$ do peptídeo homólogo. Os resultados estão expressos como a média geométrica (com o desvio padrão) do valor de CFS por $5 \times 10^{5}$ células do baço para cada grupo ( $\mathrm{n}=5$ animais).

Fonte: Medina-Armenteros (2012)

O resto dos peptídeos não ativou a liberação de IFN- $\gamma$ por linfócitos T CD8. O peptídeo Y2 que representa o epítopo imunodominante de células TCD8 (M282-90), também teve uma resposta baixa com um valor de apenas $10 \mathrm{CFS} / 5$ x $10^{5}$ células do baço. Comparando com 
experimentos anteriores a resposta de liberação IFN- $\gamma$ foi maior quando administrados os peptídeos de mais de 9 aa (figuras 15 e 19).

Esses peptídeos de 9 aa também foram testados no contexto da infecção viral (figura 21), sendo observada uma resposta de spots baixa. Os linfócitos pulmonares (figura 21, painel a) não responderam frente à estimulação com os peptídeos avaliados. Por outro lado, os linfócitos do baço (figura 21, painel b) estimulados, ex vivo, tiveram uma resposta de CFS, embora baixa. Os valores foram 2, 3 e 2 CFS/ 5x $10^{5}$ células para S8.1, S8.3 e S11.1, respectivamente. Quando adicionado o anticorpo anti-CD8, o número de spots produzidos pelos 3 peptídeos diminui para $1 \mathrm{CFS} / 5 \times 10^{5}$ células. O peptídeo imunodominante Y2 apresentou uma resposta de spots alta tanto por linfócitos pulmonares (painel a) quanto por linfócitos do baço (painel b). Os valores de CFS obtidos foram de 70 e 105, respectivamente, caindo para 28 e 83 na presença do anticorpo anti-CD8. Essa queda representa uma redução de $60 \%$ de linfócitos pulmonares e de $21 \%$ de linfócitos do baço produzindo IFN- $\gamma$.

Figura 21- Resposta de liberação de IFN- $\gamma$ na infecção viral contra os peptídeos de 9-mer.

a)

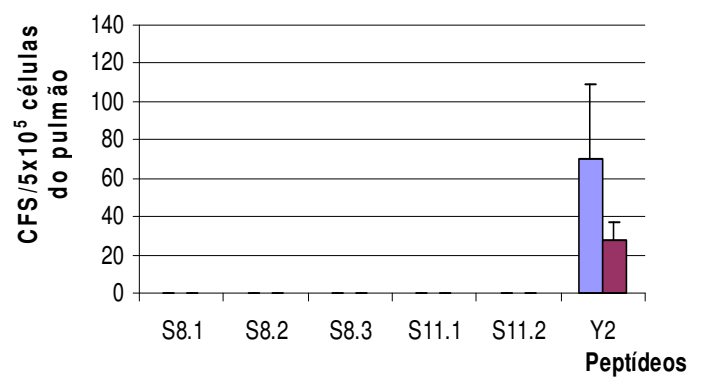

b)

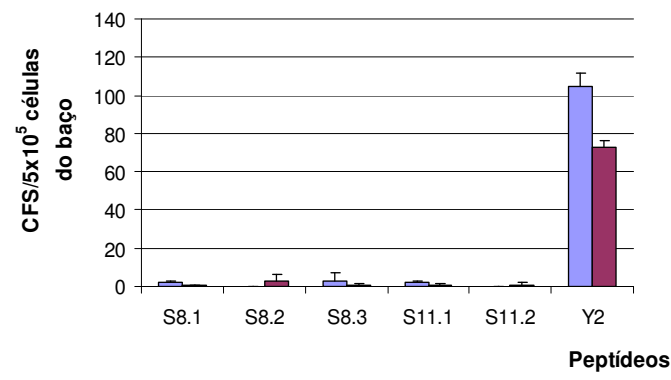

$$
\begin{array}{ll}
\square & \text { - anti CD8 } \\
\square & \text { + anti CD8 }
\end{array}
$$

Os animais foram infectados com $1,5 \times 10^{6}$ UFS/animal de HRSV pela via intranasal. Células do pulmão e baço foram coletadas 7 dias após infecção e estimuladas ex vivo com 250 ng dos peptídeos indicados. O resultado está expresso como a média geométrica de CFS específicos de linfócitos do pulmão (painel a) ou do baço (painel b), na presença ou ausência do anticorpo anti-CD8 para cada grupo ( $\mathrm{n}=5$ animais).

Fonte: Medina-Armenteros (2012) 
O valor de CFS para o grupo imunizado com Y2 e estimulado com o peptídeo homólogo foi baixo (figura 20), em contraste com o valor alto de CFS observado na infecção viral e estimulação com esse mesmo peptídeo. O valor de CFS na infecção viral e estimulação com os peptídeos de 9-mer testados, porém, foi baixo (figura 21). A redução do número de CFS na presença do anticorpo anti-CD8 para S8.1, S8.3 e S11, foi de 50, 66,6 e $50 \%$, respectivamente. Os peptídeos de 9-mer que ativaram a produção de IFN- $\gamma$ na infecção viral (figura 21), somados aqueles que ativaram a produção da citocina quando utilizados como imunógenos (figura 20), indicam que os cinco peptídeos testados levaram a uma resposta de liberação de IFN- $\gamma$, e que eles constituem epítopos de células TCD8.

\subsection{Expressão das proteínas recombinantes}

\subsubsection{Purificação e análise de CTB e GMCTB}

As proteínas CTB e GMCTB foram purificadas em condições desnaturantes já que elas são expressas majoritariamente em forma insolúvel nos corpúsculos de inclusão em $E$ coli. Após processamento e purificação (ver item 3.2.4 de material e métodos), constatam-se na figura 22, a purificação e renaturação de CTB (painel a) e GMCTB (painel b) por meio de Western Blot. Foram observadas as bandas de aproximadamente $72 \mathrm{kDa}$ (painel a, canaletas 1 e 2) e $90 \mathrm{kDa}$ (painel b, canaletas 1 e 2) correspondentes aos pentâmeros de CTB e GMCTB, respectivamente. Também foram detectadas bandas de menor tamanho cuja altura indica que podem ser monômeros (seta azul), dímeros (seta roxa) ou trímeros (seta cinza) dessas proteínas, considerando que os monômeros de CTB têm uma massa molecular aproximada de $14,1 \mathrm{kDa}$ e os de GMCTB de $18,5 \mathrm{kDa}$. A CTB é a porção não tóxica da holotoxina e a responsável pela ligação ao receptor gangliosídeo GM1, um glicolipídeo que é expresso constitutivamente na maioria das células humanas (Arêas et al., 2004).

A funcionalidade dos pentâmeros formados foi medida, testando a ligação das proteínas ao GM1 por meio de ELISA (figura 22, painel c). Foi observado que tanto CTB quanto GMCTB se ligam ao GM1 determinado pela leitura da DO a 492nm, a diferença da CTB 
Figura 22- Análise das proteínas CTB e GMCTB purificadas.

a)

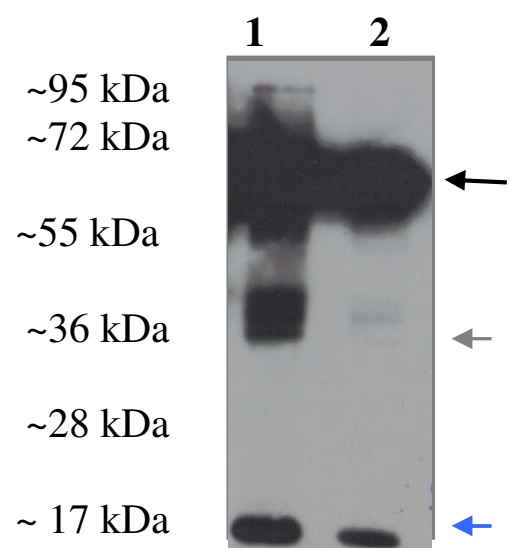

CTB b)

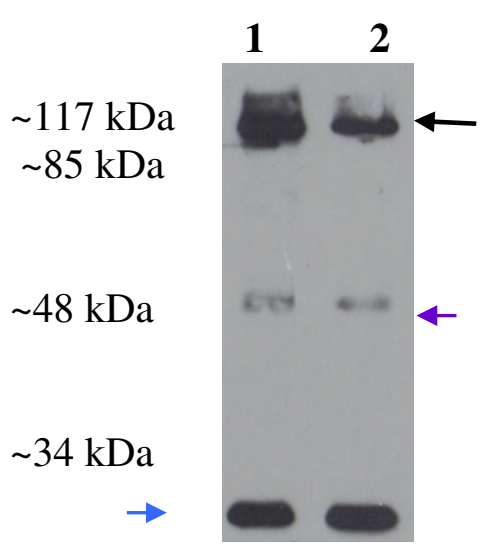

GMCTB

c)

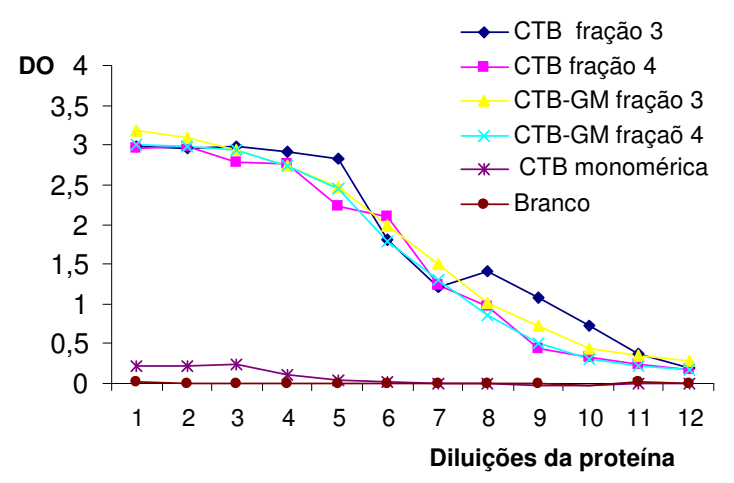

Western Blot anti-CTB (painel a) e anti-GMCTB (painel b) das frações 3 e 4 purificadas (canaleta 1 e 2 , respectivamente) de cada proteína (ver item 3.2.4). Detecção com o anticorpo policlonal anti-CTB 1: 7.000. O painel c mostra o teste de ligação ao receptor GM1 por ELISA, de diluições seriadas em base 2 das frações 3 e 4 purificadas de CTB e GMCTB. Os valores são apresentados como unidades de DO a 492nm. Como controle negativo foi usada a proteína CTB monomérica.

Fonte: Medina-Armenteros (2012)

monomérica que tem um comportamento similar ao branco utilizado. Esse resultado demonstra que a adição das seqüências peptídicas GM expressas em fusão com CTB, não impede a formação dos pentâmeros entre as CTBs, conformação requerida para se ligar ao seu receptor. Tanto a conjugação como a fusão genética à CTB podem levantar uma forte resposta mucosal de anticorpos contra o antígeno ligado a ela (Arêas et al., 2004). Por isso é importante a formação dos pentâmeros por GMCTB, e espera-se que uma resposta imune mucosal seja 
direcionada contra o peptídeo GM, especificamente no trato respiratório, local onde ocorre a infecção pelo HRSV. Outro aspecto interessante a salientar é o fato de que o protocolo de renaturação por diluição empregado foi efetivo.

\subsubsection{Preparação de proteínas para imunização}

Uma vez purificadas as proteínas CTB e GMCTB, verificada a renaturação e a sua ligação ao receptor de membrana GM1, elas foram concentradas passando por filtros Amicon de tamanho de poro $50 \mathrm{kDa}, 30 \mathrm{kDa}$ e $3 \mathrm{kDa}$, sucessivamente. O último concentrado obtido em filtro de $3 \mathrm{kDa}$ foi analisado para a presença da proteína e a pureza por eletroforese em gel de poliacrilamida $13 \%$ em condições desnaturantes e não desnaturantes. Na figura 23 está apresentada a eletroforese das soluções de proteínas CTB e GMCTB. São observadas bandas na altura dos $19 \mathrm{kDa}$ para GMCTB (canaletas 2 e 4), sendo mais forte a banda da canaleta 4 ,

Figura 23- SDS-PAGE das proteínas concentradas.

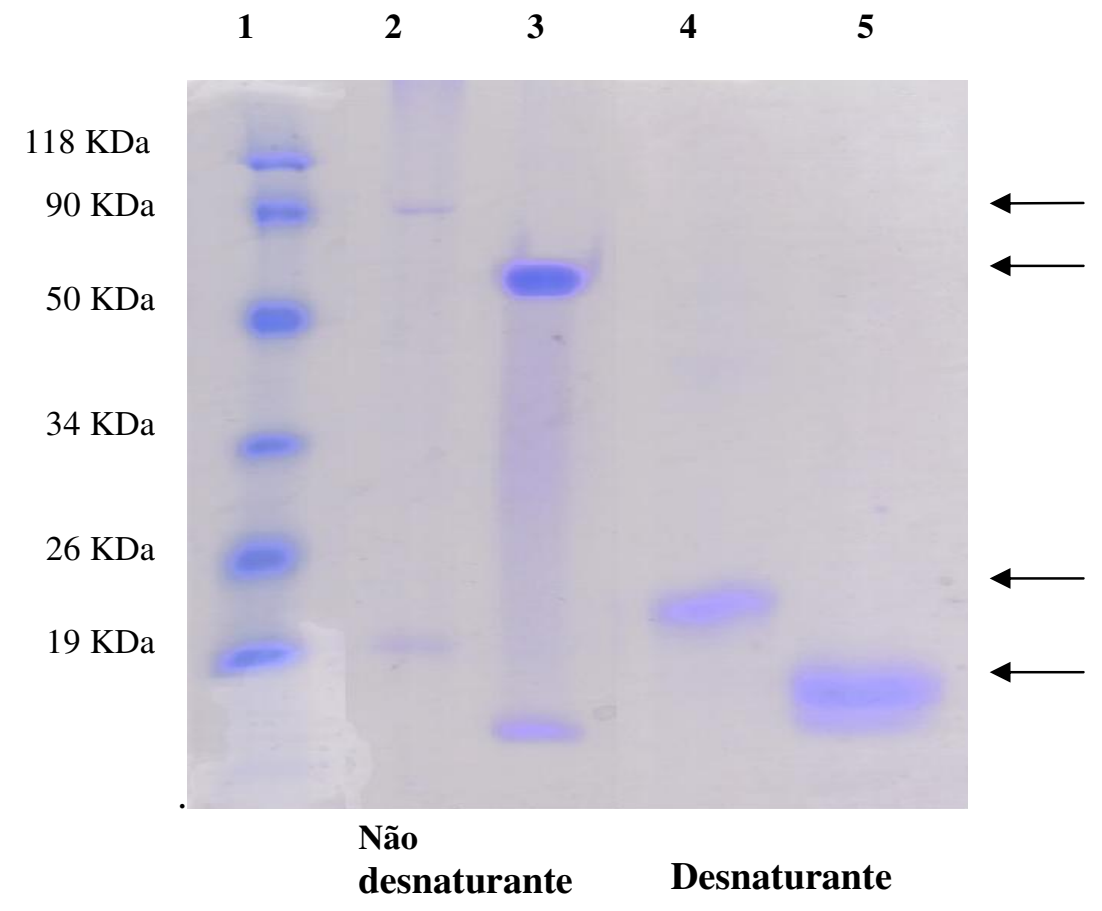

Está apresentado SDS-PAGE $13 \%$ de proteínas concentradas em condições desnaturantes e não desnaturantes. Canaleta 1, marcador de massa molecular da Fermentas (Prestained protein); canaletas 2 e 4, GMCTB; canaletas 3 e 5, CTB.

Fonte: Medina-Armenteros (2012) 
correspondente ao gel desnaturante. Na canaleta 2 também é observada uma banda na altura de $90 \mathrm{kDa}$ correspondente à forma pentamérica da proteína GMCTB. A proteína CTB foi satisfatoriamente concentrada, aparecendo uma banda abaixo dos $19 \mathrm{kDa}$ do marcador, correspondente à forma monomérica de CTB (canaleta 3). Também, foi detectada uma banda de aproximadamente 70kDa (canaleta 3), correspondente à forma pentamérica de CTB. Não foram observadas bandas de outro tamanho em nenhuma das amostras o que indica a pureza da proteína. As proteínas purificadas e concentradas foram usadas nos ensaios de imunização e ELISA.

\subsection{Análise da imunogenicidade das proteínas baseadas no peptídeo GM}

\subsubsection{Resposta imune humoral}

Para avaliar a capacidade imunogênica das proteínas baseadas em GM (GMCTB e o peptídeo sintético GM), elas foram inoculadas em camundongos Balb/c utilizando as vias, intranasal e intraperitoneal (ver itens 3.2.6.1.1 e 3.2.6.1.2). A via intraperitoneal tem sido mostrada como eficaz na indução de resposta imune humoral. No entanto, a estimulação da imunidade de mucosa contra o HRSV é um aspecto crítico para o desenvolvimento de uma vacina, por isso testamos as duas vias em esquemas de imunização diferentes. Foi analisada a presença de anticorpos reativos para GM no soro dos animais imunizados, por meio de um ensaio ELISA, para os seguintes grupos de imunização: peptídeo GM, peptídeo GM coadministrado com CTB (GM + CTB), e a proteína de fusão GMCTB. O título de anticorpos foi de 3614, 1611 e 4033, respectivamente, para os soros dos animais imunizados via intraperitoneal com os grupos mencionados (figura 24). Tanto os soros dos animais imunizados com PBS quanto com CTB não apresentaram reatividade frente ao GM; indicando que a resposta de anticorpos obtida nos outros grupos é específica. 
Figura 24- ELISA dos soros de animais imunizados via intraperitoneal com as proteínas baseadas em GM.

a)

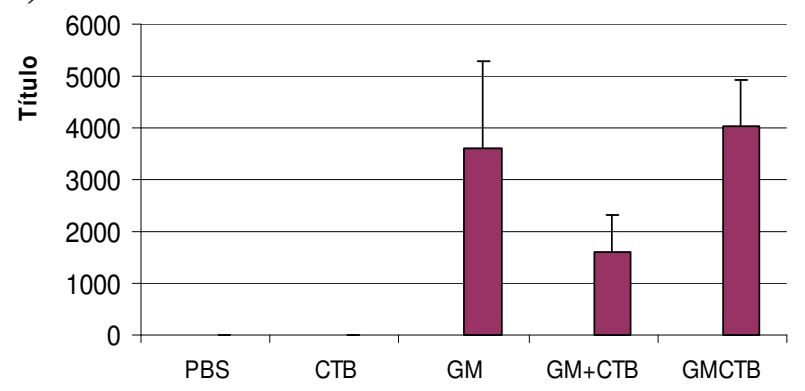

b)

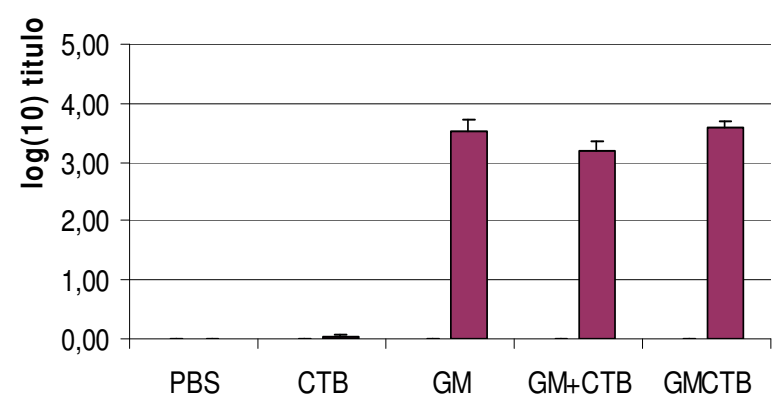

$\square$ Pré-imune

$\square$ Coleta 3

Estão apresentados os resultados para os soros pré-imunes e da coleta 3 (10 dias após a quarta dose). As placas foram sensibilizadas com 50ng/poço de peptídeo sintético GM. Os dados estão expressos como a média geométrica (e desvios padrões) do título (painel a) ou log (10) do título (painel b) para cada grupo ( $\mathrm{n}=5$ animais).

Fonte: Medina-Armenteros (2012)

Em contraste ao observado para a via intraperitoneal, a imunização via intranasal com as proteínas derivadas de GM, não foi capaz de induzir anticorpos IgG reativos para o peptídeo GM (figura 25). Os valores de absorbância observados foram menores que 0,1. Congruente com este resultado, também não foram detectados anticorpos IgA específicos para GM na saliva (figura 26). As amostras de saliva de animais imunizados com CTB tiveram uma resposta similar aos imunizados com GM e GM+CTB. Além disso, o grupo PBS também apresentou uma reatividade com valores de absorbância baixos. Concluímos que a inoculação intranasal com as proteínas baseadas em GM não foi capaz de induzir resposta imune humoral tanto sistêmica quanto de mucosa. 
Figura 25- ELISA dos soros de animais imunizados via intranasal com as proteínas baseadas em GM.

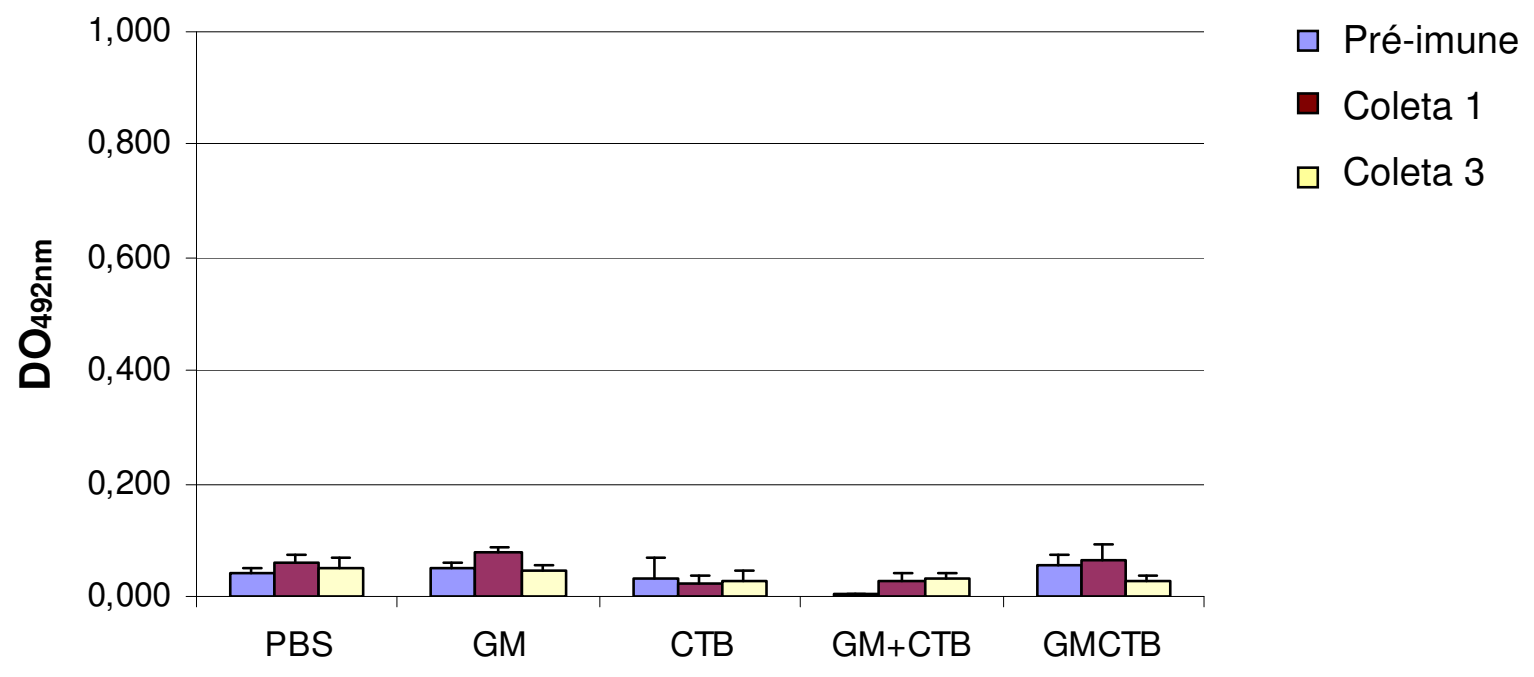

Estão apresentados os resultados para os soros: pré-imune, coleta 1 (10 dias após a segunda dose) e coleta 3 (10 dias após a quarta dose), na diluição 1:100. As placas foram sensibilizadas com 200ng de peptídeo sintético GM. Os dados estão expressos como a média geométrica (e desvios padrões) da DO a $492 \mathrm{~nm}$ por grupo ( $\mathrm{n}=5$ animais).

Fonte: Medina-Armenteros (2012)

Figura 26- ELISA da saliva de animais imunizados via intranasal com as proteínas baseadas em GM.

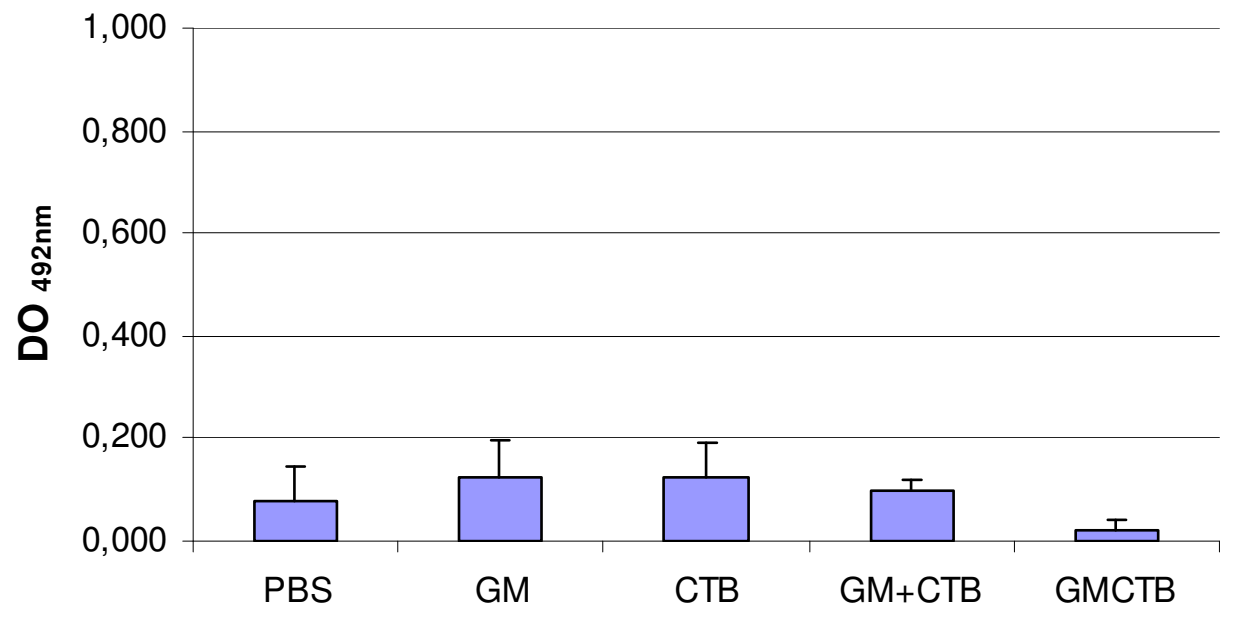

Estão apresentados os resultados para análise das salivas após coleta 3 (10 dias após a quarta dose, ver figura 4), na diluição 1: 50. As placas foram sensibilizadas com 200ng de peptídeo sintético GM. Os dados estão expressos como a média geométrica (e desvios padrões) da DO a 492nm por grupo ( $\mathrm{n}=5$ animais).

Fonte: Medina-Armenteros (2012) 


\subsubsection{Resposta imune protetora}

\subsubsection{Ensaio de neutralizacão}

Uma vez constatada a capacidade das proteínas GM e GMCTB de induzir a produção de anticorpos contra GM, quando administradas via intraperitoneal, foi avaliada a capacidade neutralizante deles. Para isso, foi realizado um ensaio de neutralização em células HEp-2, analisando a presença ou ausência do efeito citopático característico de formação de sincícios, por observação microscópica. Foi encontrado que os anticorpos produzidos contra os imunógenos GM, GM+CTB ou GMCTB, não foram capazes de bloquear a ligação do vírus às células susceptíveis e conseqüentemente a infecção viral (figura 27a). Apareceram sincícios na monocamada das células infectadas com HRSV pré-incubado com os soros avaliados, bem como com o anticorpo monoclonal C793 (anti-G). Este anticorpo é usado para reconhecer a proteína $\mathrm{G}$ no ensaio de imunofluorescência, e o resultado de não neutralização é congruente com o fato de que nenhum anticorpo monoclonal anti-G reportado ser altamente neutralizante, em contraste com soros policlonais ou pool de anticorpos anti-G (Martínez e Melero, 1998). A monocamada das células sem infectar (infecção mock), mostrou ausência de sincícios (figura 27b).

\subsubsection{Carga viral}

Como parte da capacidade protetora resultante de um processo de imunização espera-se que ocorra uma redução da carga viral frente a um desafio. Para avaliar este aspecto, quatorze dias após a quarta e última dose de proteínas, camundongos Balb/c foram desafiados com $3 \times 10^{6}$ UFS de HRSV, via intranasal. Cinco dias após infecção os animais foram sacrificados e coletados os pulmões para extração de RNA total. O RNA isolado serviu de molde para a síntese de cDNA segundo o descrito no item 3.2.10.2. Assim, o RNA viral foi quantificado num ensaio de real time qPCR (item 3.2.10.3). Escolhemos desafiar apenas os animais imunizados via intraperitoneal, dada a ausência de resposta imune humoral nos amimais imunizados via intranasal. 
Figura 27- Ensaio de neutralização do HRSV.

a)

PBS

GM

GM+CTB

GMCTB

b)
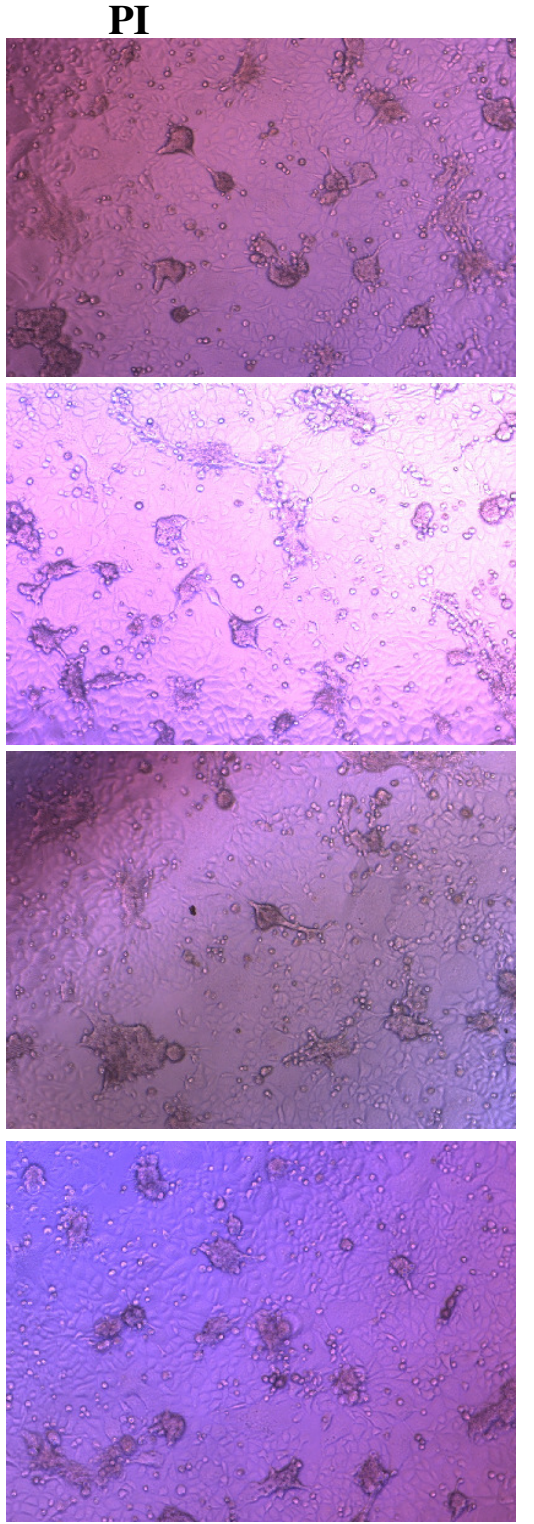

C793

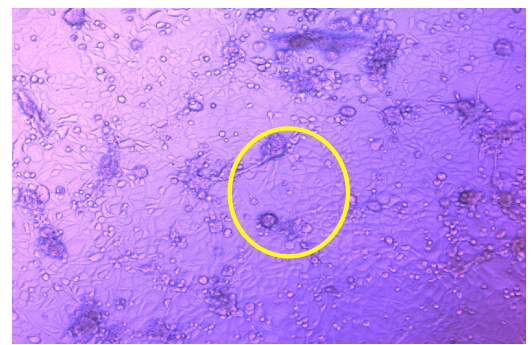

Coleta 3
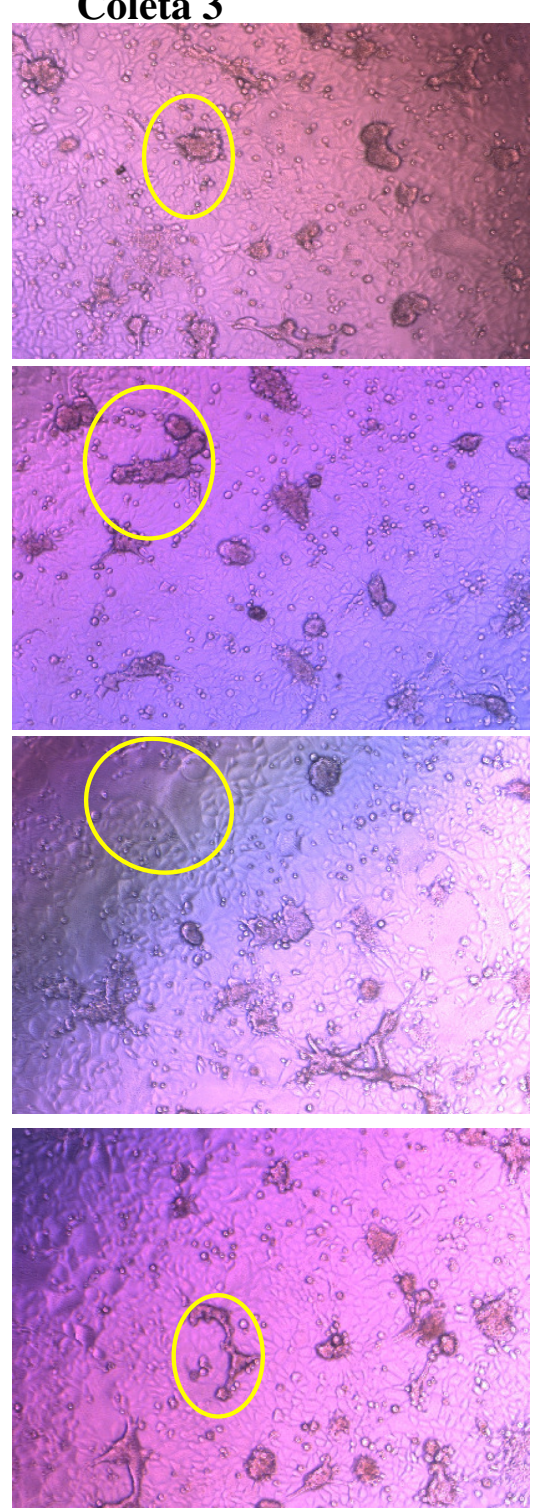

Infeccão "Mock"

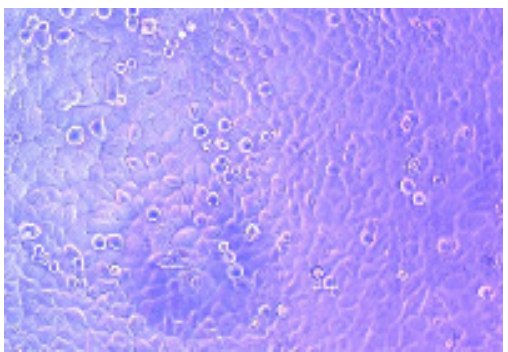

Está apresentada microscopia de campo claro de células HEp-2 infectadas com uma MOI de HRSV pré-incubada com os soros (1:100) de animais imunizados via intraperitoneal com as proteínas indicadas. As fotos foram tomadas 48 hs após infecção, painel a). Como controle foi usado o monoclonal anti-G C793 painel b). Aumento 100x, os círculos amarelos indicam sincícios.

Fonte: Medina-Armenteros (2012) 
O gráfico da figura 28 mostra o número de cópias de RNA do genoma do HRSV encontrado nos pulmões dos animais imunizados. Não houve redução da carga viral para nenhum dos grupos experimentais que tinham GM como imunógeno (GM, GM+CTB ou GMCTB) comparado com o grupo PBS, que foi apenas imunizado com adjuvante de Freund.

Figura 28- Carga viral em animais imunizados via intraperitoneal com proteínas baseadas em GM.

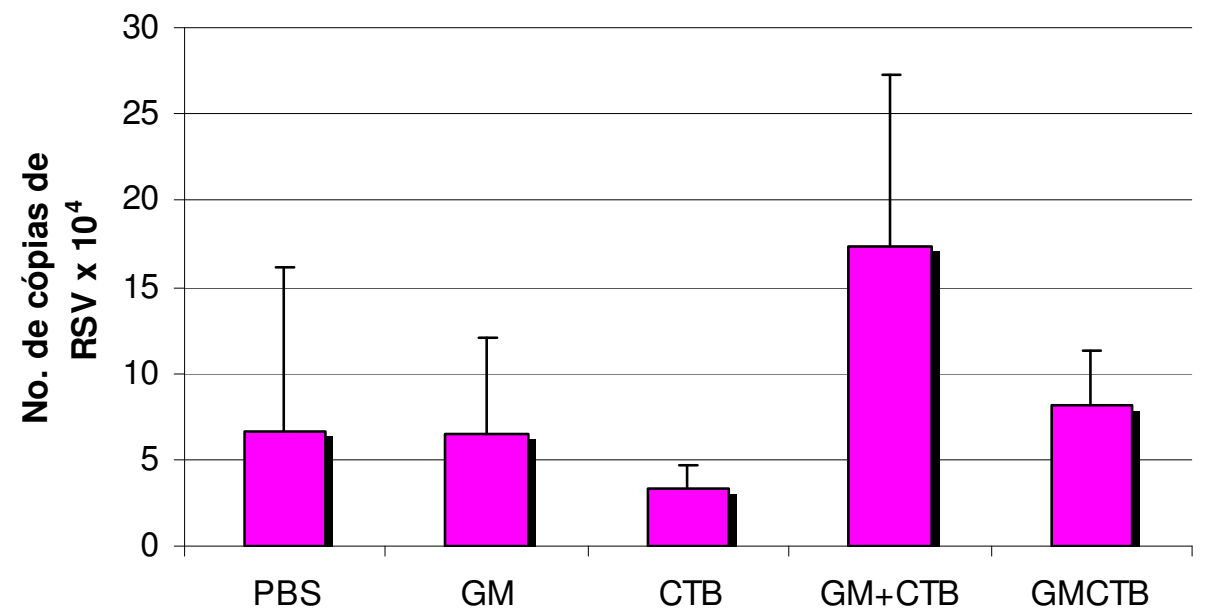

Quantificação por real time qPCR a partir do RNA isolado de pulmões, no quinto dias após desafio. Os resultados são expressos como a média geométrica (e desvios padrões) do número de cópias $\times 10^{4}$ de RNA viral, medida por amplificação de uma sequiência do gene $\mathrm{N}$, para cada grupo ( $\mathrm{n}=5$ animais).

Fonte: Medina-Armenteros (2012)

Este resultado é congruente com o obtido no ensaio de neutralização onde os anticorpos presentes nos soros dos animais imunizados não foram capazes de bloquear a infecção de células HEp-2. Os valores de carga viral para GM+CTB e GMCTB obtidos foram maiores que para PBS, enquanto para CTB foram menores, porém essas diferenças não são estatisticamente significativas. Essa variabilidade na quantidade de vírus recuperado do pulmão pode ser explicada pelo fato de que a via de administração intranasal empregada apresenta dificuldades técnicas para garantir a mesma efetividade na inoculação do vírus, de um animal para outro. 


\subsubsection{Análise histopatológica}

A análise dos cortes de pulmão revelou que os camundongos imunizados e desafiados não apresentaram lesões moderadas nem intensas (ver tabela 2 no item 3.2.11), em decorrência da infecção viral. Os valores de escore para cada tipo de lesão estão apresentados na tabela 5. Esse escore baixo foi observado tanto para animais imunizados com PBS quanto para aqueles imunizados com proteínas baseadas em GM, apesar dos anticorpos induzidos por esses imunógenos não serem neutralizantes.

Tabela 5- Histopatologia dos pulmões de animais imunizados com proteínas baseadas em GM.

\begin{tabular}{|c|c|c|c|c|c|c|}
\hline Grupos & $\begin{array}{l}\text { Pneumoni } \\
\text { a }\end{array}$ & $\begin{array}{l}\text { Hiperplasi } \\
\text { a }\end{array}$ & Linfócitos & Macrófagos & Eosinófilos & $\begin{array}{l}\text { Gera } \\
\text { l }\end{array}$ \\
\hline PBS & 1.3 & 1.0 & 0.3 & 2.0 & 1.0 & 5.4 \\
\hline GM & 1.3 & 0.3 & 0.7 & 1.3 & 1.0 & 4.0 \\
\hline CTB & 1.0 & 0.3 & 0.7 & 1.0 & 1.0 & 3.4 \\
\hline $\mathbf{G M}+\mathbf{C T B}$ & 1.0 & 0.7 & 0.3 & 1.0 & 0.3 & 5.3 \\
\hline GMCTB & 1.3 & 1.0 & 0.7 & 1.3 & 0.7 & 4.4 \\
\hline
\end{tabular}

Os valores representam a média geométrica do escore de histopatologia para cada grupo.

Fonte: Medina-Armenteros (2012)

No gráfico da figura 29 está representado o escore geral de histopatologia para cada grupo. Os grupos PBS e GM+CTB apresentaram o valor de escore maior enquanto o grupo CTB teve o escore menor. Os valores de carga viral obtidos para cada grupo explicam os escores gerais observados. O grupo que apresenta menor carga viral (CTB) apresenta o menor escore geral de histopatologia. As lesões observadas são provocadas em decorrência da replicação viral como acontece no grupo GM+CTB com a maior carga viral e um escore geral de 5,3. No entanto, a intensidade da presença de eosinófilos, parâmetro que caracteriza a doença exacerbada, foi discreta para todos os grupos experimentais. 
Figura 29- Histopatologia de pulmões de animais imunizados via intraperitoneal com proteínas baseadas em GM, após desafio.

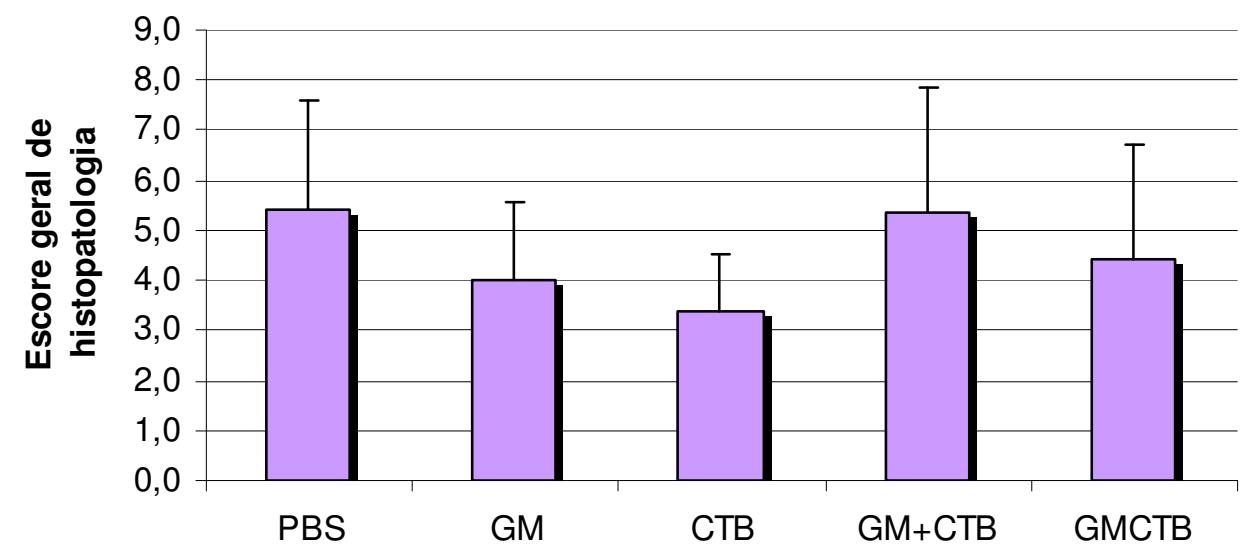

Os valores representam a média geométrica (e desvios padrões) do escore de histopatologia geral para cada grupo experimental ( $\mathrm{n}=5$ animais).

Fonte: Medina-Armenteros (2012)

\subsection{Obtenção das vacinas de DNA (pT, pTGM, pTCTB e pTGMCTB)}

Uma vez obtido, o inserto que codifica para a seqüência sinal de exportação do TpA foi ligado ao vetor pcDNA3 entre os sítios de HindIII e EcoRV. A reação de ligação foi precipitada, bactérias DH10B transformadas com o DNA purificado, e os plasmidios das colônias selecionadas foram purificados. A figura 30 mostra a análise por digestão dupla com as enzimas HindIII e EcoRV que libera apenas um fragmento de 78pb correspondente ao inserto. Dos 9 clones analisados apenas 3 (pT3, pT6 e pT8) foram positivos, apresentando um único fragmento na altura de $80 \mathrm{pb}$ do marcador. O posterior seqüênciamento confirmou que o pT6 possuia a seqüência sinal do TpA correta. 
Figura 30- Obtenção do plasmídio pT.

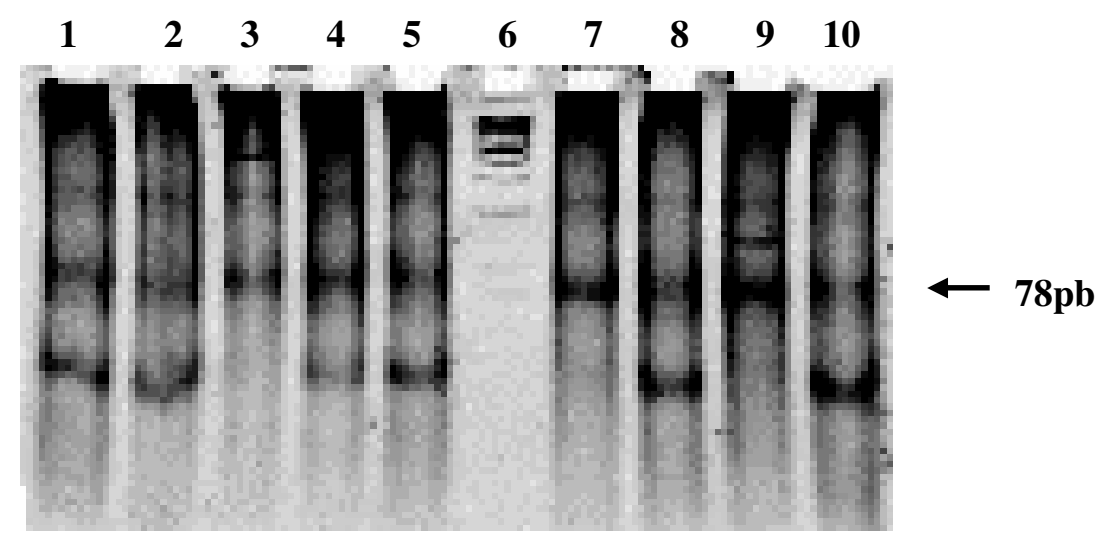

Está apresentada a eletroforese em gel de acrilamida $15 \%$ da digestão dupla com as enzimas HindIII e EcoRV do plasmídio pT obtido pela ligação de pcDNA3 com o inserto correspondente à seqüência sinal de TpA. Canaletas 1-5: clones 1-5; canaletas 7-10: clones 6-9; e canaleta 6: marcador 100pb da Fermentas.

Fonte: Medina-Armenteros (2012)

Para a obtenção de pTGM, pTCTB e pTGMCTB os insertos GM, ctxB e GM-ctxB foram amplificados e clonados em pT. Eles foram inseridos entre os sítios EcoRV e XbaI na mesma fase de leitura da seqüência sinal do TpA (ver item 3.2.5.2 de material e métodos). Nos experimentos de screening, dos 29 clones analisados de pTGM apenas 2 (pTGM14 e pTGM17) foram positivos. O plasmídio pTGM17 foi purificado e digerido com PstI e Ava II (figura 31, painel a). A digestão com PstI libera 2 bandas, uma de 4117 e outra de 1445pb. A digestão com AvalI devia render 4 bandas, 2 muito próximas de 1866 e 1863 visualizadas como única, uma de 1611 e outra de $222 \mathrm{pb}$. A figura 31, painel a, mostra que foi obtido o padrão de bandas esperado para esse plasmídio, que por seqüenciamento confirmamos estar correto. 
Figura 31- Obtenção dos plasmídios pTGM, pTCTB e pTGMCTB.

a)

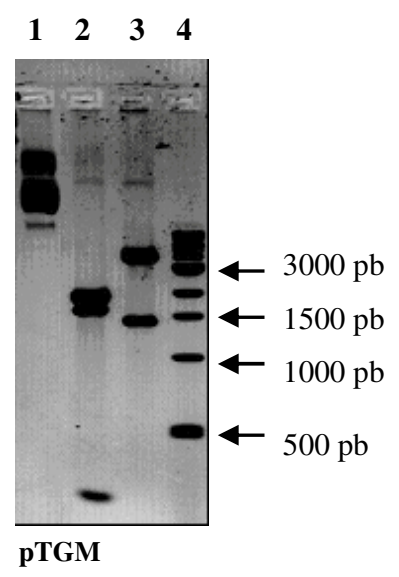

b)

$\begin{array}{lllllll}1 & 2 & 3 & 4 & 5 & 6 & 7\end{array}$

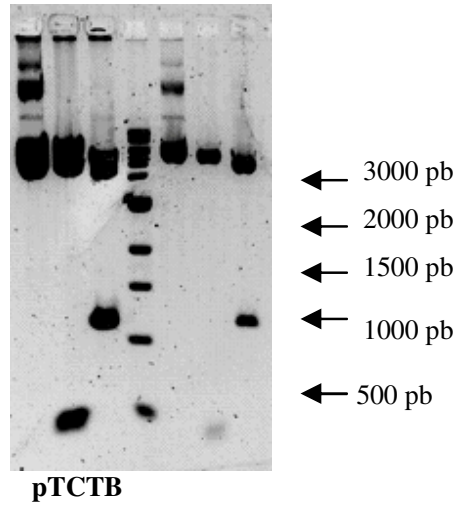

c)

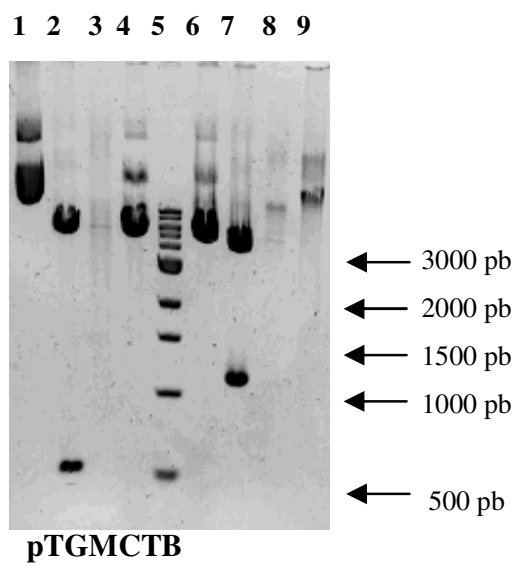

Eletroforese em gel de agarose 1\%. Painel a, análise de pTGM 17. Canaleta 1: plasmídio sem digerir; canaleta 2: digerido com AvaII; canaleta 3: digerido com PstI, canaleta 4: marcador $1 \mathrm{~Kb}$ da NEB. Painel b, análise de pTCTB. Canaletas 1-3: pTCTB 1 sem digerir, digerido com BstXI, e com SmaI, respectivamente. Canaletas 5-7: pTCTB 2 na mesma ordem que pTCTB 1. Canaleta 4: marcador $1 \mathrm{~Kb}$ da NEB. Painel c, análise de pTGMCTB. Canaleta 1: pTGMCTB 5 sem digerir; canaletas 2-4: digestão com BstXI de pTGMCTB 5, pTGMCTB 18 e pT6, respectivamente. Canaletas 6-8: digestão com SmaI de pT6, pTGMCTB5 e pTGMCTB 18, respectivamente. Canaleta 9: pTGMCTB 18 sem digerir. Canaleta 5: marcador $1 \mathrm{~Kb}$ da NEB.

Fonte: Medina-Armenteros (2012)

O screening de clones de bactérias contendo pTCTB foi feito por digestão com as enzimas de restrição BstXI e SmaI. Obtivemos 12 colônias positivas de 20 analisadas (dados não mostrados). A figura 31 (painel b) mostra a digestão dos plasmídios pTCTB 1 e 2, que foram os selecionados. A digestão com BstXI produz duas bandas de 5380 e 378 pb, enquanto com SmaI produz 2 bandas de 4639 e $1121 \mathrm{pb}$, padrão observado para ambos plasmídios. Em contraste, pTGMCTB só teve 2 clones positivos de 29 analisados por digestão com SmaI (dados não mostrados). Os plasmídios pTGMCTB 5 e pTGMCTB 18 foram analisados por digestão com as enzimas BstXI e SmaI. A figura 31 painel c, mostra a presença das bandas de 5382 e 376 pb (canaleta 2) apenas para o pTGMCTB5, padrão de bandas esperado para digestão com BstXI. A digestão de pTGMCTB 5 com SmaI gerou bandas de 4771 e 1121 pb como era esperado, enquanto o pTGMCTB18 não apresentou o padrão de bandas certo. Por seqüenciamento confirmamos que os plasmídios pTCTB1 e pTGMCTB5 estão corretos. 


\subsubsection{Análise da expressão dos vetores plasmidiais pTGM, pTCTB e pTGMCTB}

Para conferir a expressão das proteínas recombinantes pelas vacinas de DNA, os plasmídios foram transfectados em células HEK-293T e a expressão dos mesmos foi verificada por ensaio de imunofluorescência, conforme descrito no item 3.1.18. A figura 32 mostra a expressão das proteínas CTB e GMCTB detectadas por imunofluorescência, com

Figura 32- Detecção das proteínas recombinantes por imunofluorescência.

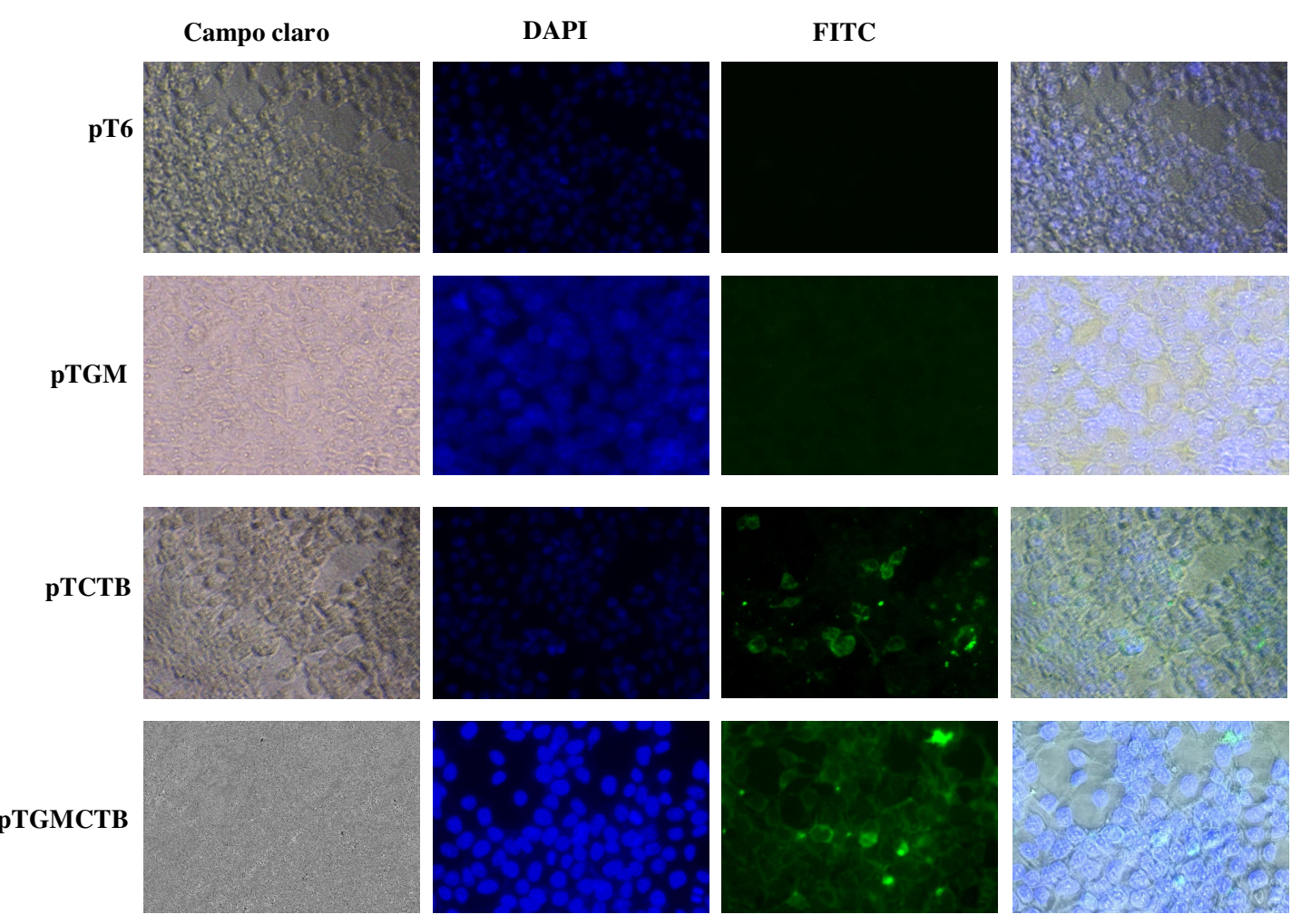

C

Células HEK 293-T foram transfectadas com os plasmídios indicados: pT, pTGM, pTCTB, pTGMCTB. Quarenta e oito horas após transfecção as células foram fixadas com metanol e coradas com anticorpo policlonal anti-GMCTB seguido do secundário anti-IgG conjugado com FITC. $\mathrm{O}$ sinal de imunofluorescência está indicado por setas amarelas. Aumento 400x.

Fonte: Medina-Armenteros (2012)

um padrão mais intenso na membrana celular. Estas proteínas não foram detectadas no meio de cultura, como era esperado pelo fato delas estarem fusionadas a TpA (dados não apresentados). Na figura 32 também é observado que não foi possível constatar a expressão do peptídeo GM com ausência de fluorescência, semelhante ao controle negativo pT6. 


\subsubsection{Análise da imunogenicidade das vacinas de DNA}

\subsubsection{Resposta imune humoral}

Após a confirmação da expressão das proteínas recombinantes CTB e GMCTB clonadas em pT, os plasmídios construídos foram empregados para imunizar camundongos Balb/c, seguindo o esquema de imunização descrito no item 3.2.6.2. O gráfico da figura 33 mostra a reatividade de anticorpos presentes nos soros dos animais imunizados (coleta 3), testados por ELISA. Os valores de absorbância observados de 0,249 e 0,662 (pré-imune e coleta 3, respectivamente) indicam que o plasmídio pTGMCTB provocou uma resposta de anticorpos sistêmica contra o peptídeo GM que não foi observada no soro dos animais imunizados com pT, pTCTB nem pTGM.

Figura 33- ELISA anti-GM dos soros de animais imunizados com vacinas de DNA.

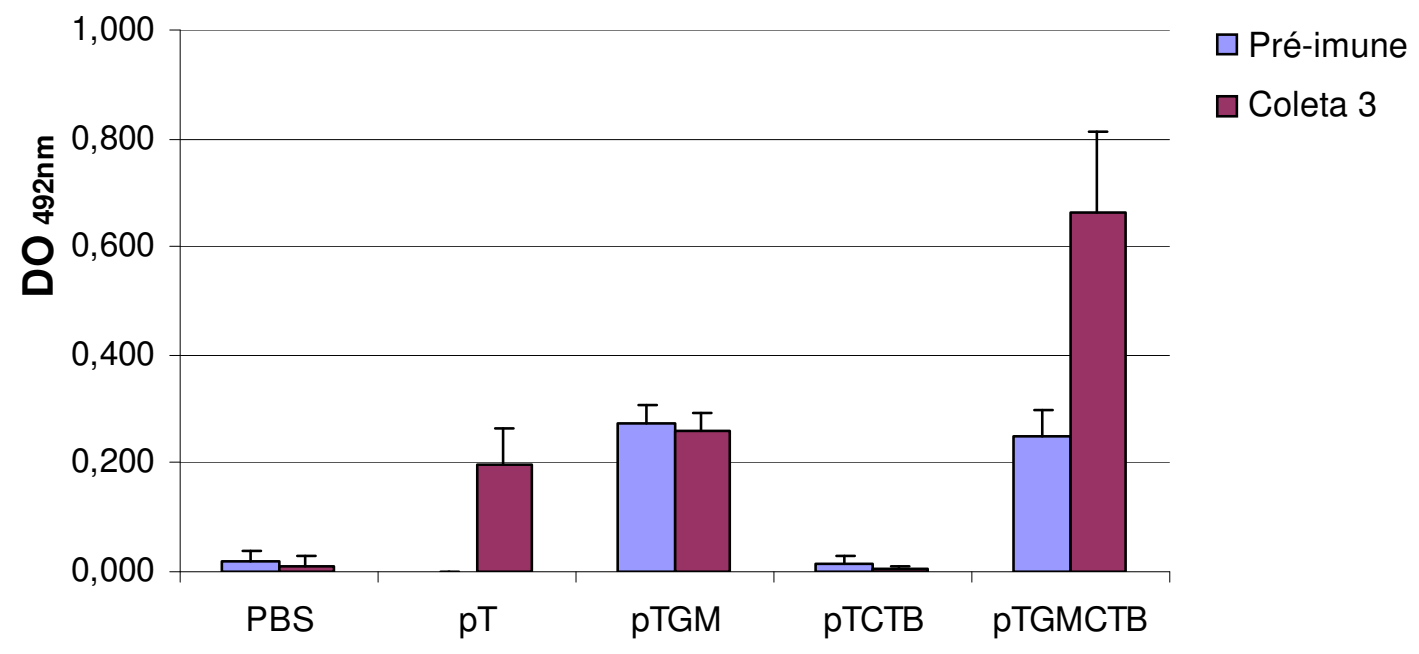

Amostras: soros pré-imune e coleta 3 (14 dias após a quarta dose) na diluição 1:100. A placa foi sensibilizada com 200ng de peptídeo sintético GM. Os dados estão expressos como a média geométrica (e desvios padrões) da DO a $492 \mathrm{~nm}$ por grupo ( $\mathrm{n}=5$ animais).

Fonte: Medina-Armenteros (2012)

A ausência de reatividade nos grupos pT e pTCTB sugere que os anticorpos antiGMCTB reativos para GM são específicos. Por outro lado, soros de animais imunizados com pTCTB e pTGMCTB foram testados para a reatividade com CTB (figura 34). O gráfico mostra valores de absorbância altos para pTCTB e pTGMCTB frente à proteína purificada 
CTB. Esse dado é consistente com os dados de expressão onde foram detectadas as proteínas recombinantes. Além disso, demonstra que o plasmídio pTCTB induziu a produção de anticorpos anti-CTB, que não reagem com GM (figura 33). Esse resultado confirma, a especificidade dos anticorpos anti-GMCTB reconhecendo o peptídeo GM, bem como o fato de que CTB é um carreador apropriado para o peptídeo GM.

Figura 34- ELISA anti-CTB dos soros de animais imunizados com vacinas de DNA.

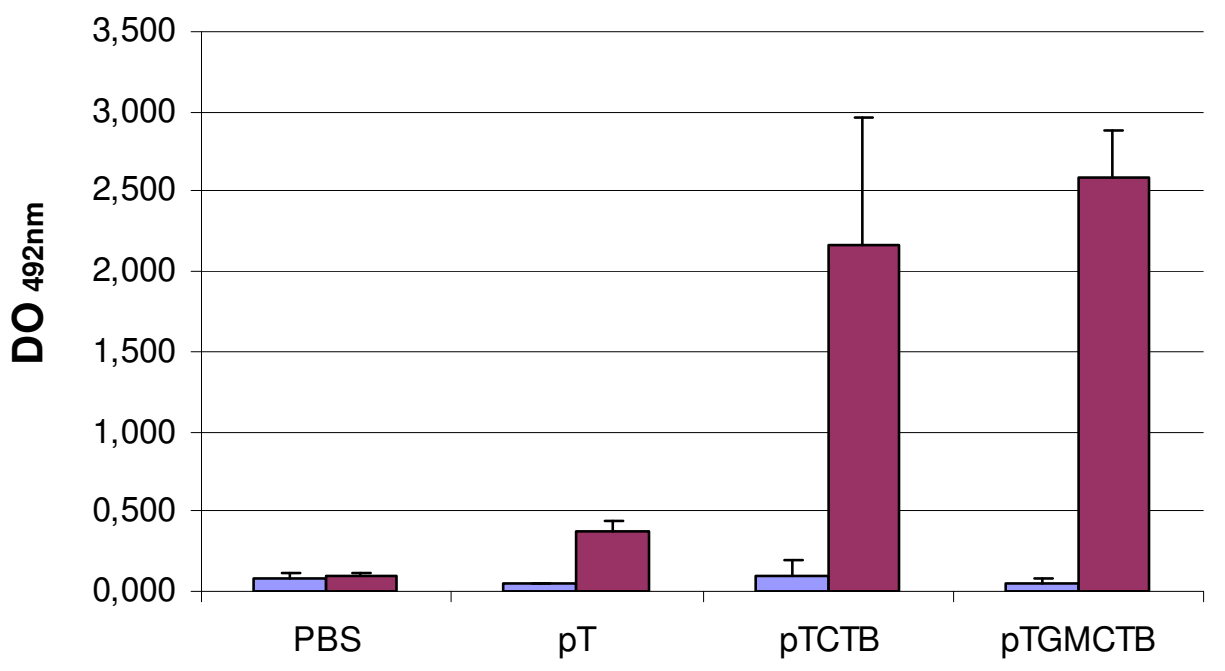

Amostras: soros pré-imune e coleta 3 (10 dias após a quarta dose) na diluição 1:100. A placa foi sensibilizada com 200ng da proteína CTB purificada. Os dados estão expressos como a média geométrica (e desvios padrões) da DO a $492 \mathrm{~nm}$ por grupo ( $\mathrm{n}=5$ animais).

Fonte: Medina-Armenteros (2012)

\section{6.2.2 Resposta imune protetora}

\section{6.2.2.1 Carga viral}

Foi avaliada a capacidade protetora das vacinas de DNA construídas. Para isso, quatorze dias após a quarta e última dose de plasmídios os animais foram desafiados com $5 \times 10^{6} \mathrm{UFS}$ de HRSV, via intranasal, procedendo-se de forma similar ao descrito no item 4.5.2.2. O gráfico da figura 35 mostra o número de cópias de RNA do genoma de HRSV encontrado nos pulmões dos animais imunizados com plasmídios. Apesar de pTGMCTB ter sido capaz de 
produzir anticorpos que reagem com o peptídeo GM, não foi observada uma redução da carga viral para os animais desse grupo, quando comparado com a carga viral obtida de pulmões de animais imunizados com PBS e o adjuvante fosfato de alumínio Os valores obtidos foram $6,81,6,87,11,7,9,46$ e 7,63 x $10^{4}$ para PBS, pT, pTGM, pTCTB e pTGMCTB, respectivamente. Esse resultado é consistente com o observado na imunização com a proteína recombinante GMCTB. Os anticorpos produzidos contra GM não foram capazes de bloquear a infecção por HRSV em células HEp-2 (figura 27), nem de reduzir a carga viral em camundongos Balb/c desafiados (figuras 28 e 35).

Figura 35- Carga viral em animais imunizados via intramuscular com vacinas de DNA.

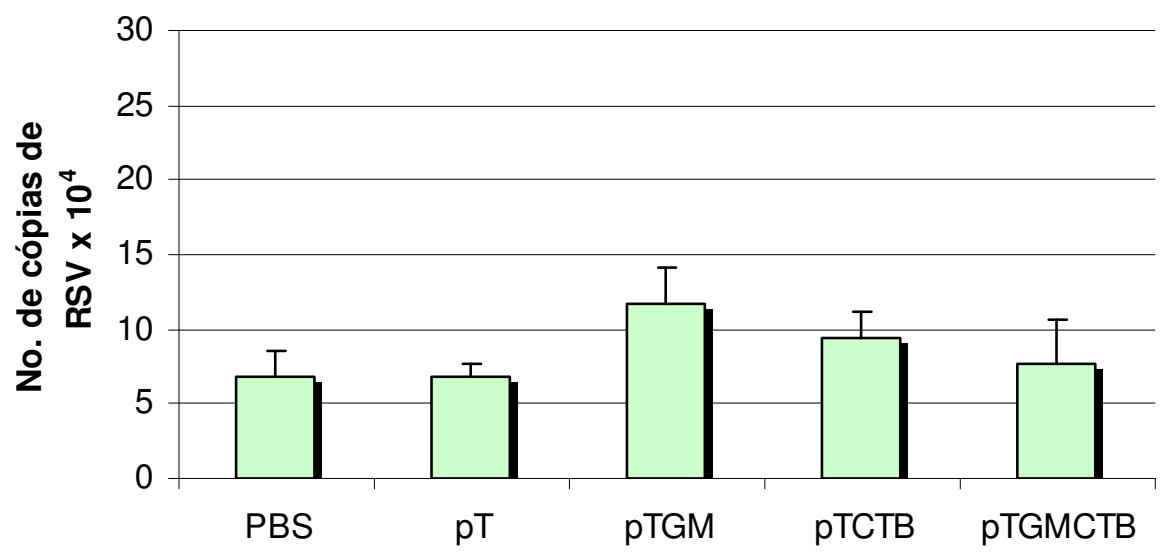

Quantificação por real time qPCR a partir do RNA isolado de pulmões, no quinto dia após desafio. Os resultados são expressos como a média geométrica (e desvios padrões) do número de cópias $\times 10^{4}$ do RNA viral, medida por amplificação de uma sequiência do gene $N$, para cada grupo ( $n=3$ animais).

Fonte: Medina-Armenteros (2012)

\section{6.2.2.2 Análise histopatológica}

Similar ao observado nos animais imunizados com as proteínas baseadas em GM, a análise dos cortes de pulmão revelou que os camundongos imunizados com plasmídios e desafiados não apresentaram lesões moderadas nem intensas (ver tabela 2 no item 3.2.11), em decorrência da infecção viral. Os valores de escore para cada lesão estão apresentados na tabela 6. Eles são baixos (lesões com intensidade discreta) tanto para animais que receberam PBS quanto para aqueles imunizados com as vacinas de DNA. O escore de histopatologia geral (figura 36) foi maior para PBS, porém não é o grupo com maior carga viral (figura 35). 
Tabela 6- Histopatologia de pulmões de animais imunizados com plasmídios.

\begin{tabular}{lccccccc} 
Grupos & Pneumonia & Hiperplasia & Linfócitos & Macrófagos & Eosinófilos & Geral \\
\cline { 1 - 4 } PBS & 1.0 & 0.7 & 0.7 & 1.0 & 0.7 & 4.0 \\
pT & 1.0 & 0 & 1.0 & 1.0 & 0.3 & 3.3 \\
pTGM & 1.0 & 0 & 0.3 & 1.0 & 1.0 & 3.3 \\
pTCTB & 1.3 & 0 & 0.3 & 0.3 & 0.7 & 3.7 \\
pTGMCTB & 1.0 & 0 & 0.3 & 1.0 & 1.0 & 3.3 \\
\hline
\end{tabular}

Os valores representam a média geométrica do escore de histopatologia para cada grupo.

Fonte: Medina-Armenteros (2012)

Figura 36- Histopatologia de pulmões de animais imunizados com vacinas de DNA após desafio.

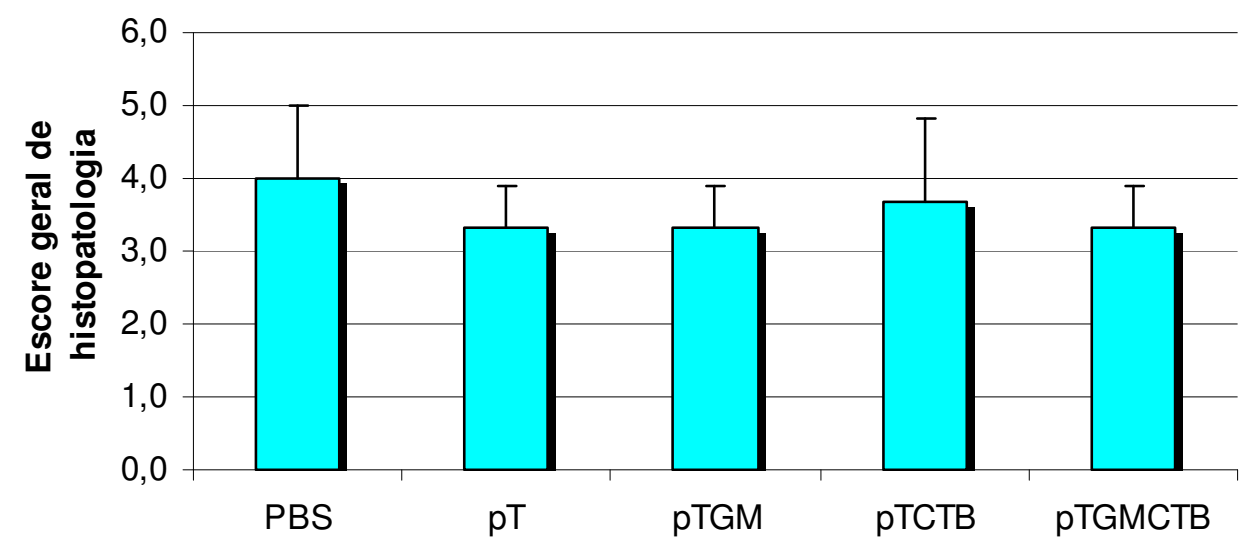

Os valores representam a média geométrica (e desvios padrões) do escore de histopatologia geral para cada grupo experimental ( $\mathrm{n}=3$ animais).

Fonte: Medina-Armenteros (2012) 


\section{DISCUSSÃO}

\subsection{Predição de epítopos na proteína $L$}

Para que uma vacina seja efetiva ela deve invocar uma forte resposta imune de células B e T; por isso, o mapeamento de epítopos é um aspecto fundamental no seu desenho (de Groot e Berzofsky, 2004; de Groot, 2006). Os métodos de predição in silico têm a capacidade de acelerar o descobrimento de epítopos consideravelmente. Nesse sentido, o escaneamento de genomas de patógenos à procura de epítopos potenciais usando algoritmos de predição, tem levado à caracterização de epítopos reais (de Groot e Berzofsky, 2004).

Epítopos de células $\mathrm{T}$ são fragmentos de peptídeos antigênicos derivados de patógenos que quando se ligam à molécula do $\mathrm{MHC}$, interagem com o receptor de células $\mathrm{T}$, depois de serem transportados à superfície de uma APC. Se for apresentada uma quantidade suficiente do epítopo, as células T podem disparar uma resposta imune específica contra o patógeno. Células T citotóxicas (CD8+) reconhecem peptídeos ligados ao MHC-I e células T helper (CD4+) reconhecem antígenos no contexto da molécula MHC-II. A molécula do MHC-I liga peptídeos de 8-15 aa dentro de uma fenda fechada. A ligação é estabilizada nas duas extremidades pelo contato entre os átomos do $\mathrm{N}$ e do C-terminais livres do peptídeo (resíduos de ancoramento) e os sítios invariáveis situados nas extremidades da fenda de todas as moléculas MHC-I. A região central do peptídeo é mais flexível (Rammensee et al., 1999).

Um dos objetivos propostos neste projeto foi avaliar a resposta imune de LTC contra a proteína L do vírus HRSV no modelo animal de camundongos Balb/c. Para atingir este objetivo foram identificados epítopos de células TCD8+ na proteína L por predição e, posteriormente, avaliamos a resposta imune celular contra peptídeos (9-17 aa) contendo epítopos. Esta proteína foi escolhida por ser altamente conservada entre as cepas de HRSV, ter um papel crucial no ciclo infeccioso do vírus, e ter sido pouco estudada com respeito à resposta imune contra ela.

A predição foi feita com os programas SYFPEITHI e PRED ${ }^{\mathrm{BALB} / \mathrm{C}}$, os quais analisam a presença de motivos de ligação aos alelos MHC-I H-2K $\mathrm{K}^{\mathrm{d}}$ e $\mathrm{L}^{\mathrm{d}}$ ou ao haplótipo de camundongo Balb/c H-2 ${ }^{\mathrm{d}}$, respectivamente (Zhang et al., 2005). A utilização desses programas permitiu selecionar 9 seqüências distribuídas ao longo da proteína L (figura 14) que continham prediptopes de 9-mer com alto escore de ligação às moléculas de MHC-I H$2 \mathrm{D}^{\mathrm{d}}$ e/ou $\mathrm{K}^{\mathrm{d}}$. Nenhuma delas continha epítopos para a molécula $\mathrm{H}-2 \mathrm{~L}^{\mathrm{d}}$, congruente com o 
reportado para Balb/c onde apenas tem sido encontrados epítopos apresentados pela molécula H-2K ${ }^{\mathrm{d}}$ (Kulkarni et al., 1995; Chang et al., 2001; Chang et al., 2002; Lee et al., 2006).

\subsection{Análise da resposta imune celular contra as seqüências da proteína $L$}

Apesar da maioria dos peptídeos que se ligam à molécula MHC-I serem de 9 aa (Rammensee et al., 1993) optamos por sintetizar peptídeos com seqüências maiores para analisar a sua imunogenicidade. Foi determinada a reposta imune celular contra 9 peptídeos selecionados da proteína L (S1, S5, S8, S9, S11, S12, S14, S15 e S16) em camundongos Balb/c. A resposta de células $\mathrm{T}$ contra os 9 peptídeos foi avaliada tanto na infecção viral como utilizando-os como imunógenos, e posterior estimulação ex vivo. Encontramos em dois desses peptídeos, S8 e S11, epítopos responsivos às células T de maneira consistente. Isso demonstra que para que um epítopo seja funcionalmente ativo, são necessários outros eventos, como clivagem no proteasoma, ligação ao transportador de membrana e ao receptor de células T (TCR) (Herd et al., 2006), além da probabilidade de ligação ao MHC-I, analisada nos programas de predição empregados. Coincidentemente, esses peptídeos apresentaram $100 \%$ de homologia entre as seqüências das cepas analisadas, portanto, são altamente conservados e estão presentes nos 2 subgrupos de HRSV (A e B), tornando-os um alvo interessante para o direcionamento da resposta imune celular. A resposta de liberação de IFN- $\gamma$ após estimulação com os peptídeos ex vivo foi reduzida pela adição de anticorpos antiCD8 no sistema ELISPOT, demonstrando que essas seqüências contem epítopos de células TCD8.

A seguir, foram testados cinco epítopos de 9-mer contidos em S8 e S11 (tabela 4). Os cinco tiveram uma resposta baixa de CFS, tanto quando usados como vacina de peptídeo (figura 20) quanto na infecção viral (figura 21). O valor de CFS para o grupo imunizado com Y2 (peptídeo imunodominante M2-1 ${ }_{82-90}$ ) e estimulado com o peptídeo homólogo, foi baixo (figura 13). Isto pode indicar uma falha na estimulação de linfócitos TCD8 respondedores ao peptídeo imunodominante quando usado como vacina devido ao adjuvante empregado. Nos ensaios de imunização foi usado adjuvante de Freund administrado em quatro doses a intervalos de uma semana. Os níveis de estimulação de resposta de células TCD8 baixos obtidos são congruentes com os relatos de uso deste adjuvante para estimular resposta imune celular. Liu e colaboradores obtiveram apenas uma baixa freqüência de células TCD8 específicas, na imunização com o peptídeo gp33-41 de LCMV (do inglês, lymphocytic choriomeningitis virus) (Liu et al., 2007). Outro grupo também demonstrou que esse 
esquema de imunização induziu uma ativação de 0,06\% de linfócitos TCD8 específicos (Kochenderfer et al., 2007). O observado para Y2 é a conseqüência da eleição dum esquema de imunização não apropriado para o tipo de resposta a ser avaliada. Dessa maneira, o uso do adjuvante de Freund não foi efetivo na ativação da resposta imune contra os peptídeos analisados, o que explica os níveis baixos de CFS obtidos nos ensaios ELISPOT. Além disso, foi demonstrado que a adição de IL-2 no sistema ELISPOT pode incrementar significativamente a resposta de células TCD8 (Kochenderfer et al., 2006). Assim, para vacinas de peptídeos são recomendados adjuvantes como CpG e IL-2 (Liu et al., 2007).

Diferente do observado na imunização com peptídeos, na infecção viral e posterior estimulação com Y2 foram obtidos valores de células produtoras de IFN- $\gamma$ altos (figura 21). O valor de CFS na infecção viral e estimulação com os peptídeos de 9-mer testados, porém, foi baixo (figura 21). Apesar das limitações do adjuvante empregado, de forma geral, a imunização com peptídeos foi capaz de gerar uma resposta de células $\mathrm{T}$ efetoras, com liberação de IFN- $\gamma$ no ELISPOT mensurável, maior que quando eles são apresentados ao sistema imune no contexto da infecção viral. Isto pode se dever a um efeito supressor do peptídeo imunodominante, como foi reportado por Mok e colaboradores. Eles mostraram que a imunogenicidade do epítopo subdominante $\mathrm{M} 2_{127-135}$ era potenciada ao mutar os resíduos de ancoramento do epítopo imunodominante $M 2_{82-90}$ (Mok et al., 2008). Esses dois peptídeos presentes na proteína M2-1 são apresentados pela mesma molécula $\mathrm{H}-2 \mathrm{~K}^{\mathrm{d}}$ podendo um competir com o outro para se ligar ao MHC-I. Dos peptídeos que propomos, S8.1, S8.2, S11.1 e S11.2 são restritos por H-2D ${ }^{d}$ (tabela 7). Os altos valores de escore de ligação ao MHC-I H-2 ${ }^{d}$ podem facilitar a apresentação deles, por não sofrerem a competição do epítopo imunodominante apresentado pelo $\mathrm{H}-2 \mathrm{~K}^{\mathrm{d}}$. Estudos mais detalhados devem ser feitos para poder determinar qual molécula MHCI realmente apresenta estes peptídeos.

Os peptídeos de 9-mer que ativaram a produção de IFN- $\gamma$ na infecção viral (figura 21) foram diferentes daqueles que ativaram a produção dessa citocina quando utilizados como imunógenos (figura 20). De forma geral os cinco peptídeos testados tiveram uma resposta similar de liberação de IFN- $\gamma$, portanto os cinco podem constituir epítopos de células TCD8. 
Tabela 7- Escore de ligação ao MHC-I dos epítopos de células TCD8 identificados.

\begin{tabular}{lclccccc}
\hline & & & \multicolumn{3}{c}{ ESCORE PRED $^{\text {BALB/C }} \mathbf{a}$} & \multicolumn{2}{c}{ SYFPEITHI $^{\mathbf{b}}$} \\
\hline Pept. & Seqüência & Posição & H-2D $^{\text {d }}$ & H-2K $^{\mathbf{d}}$ & H-2L $^{\mathbf{d}}$ & H-2K $^{\text {d }}$ & H-2L $^{\mathbf{d}}$ \\
S8.1 & IEPTYPHGL & $1114-1122$ & 9.7 & 6.1 & 5.1 & 13 & 12 \\
S8.2 & TYPHGLRVV & $1117-1125$ & 9.52 & 9.06 & 4.66 & 20 & 5 \\
S8.3 & GLRVVYESL & $1121-1129$ & 7.58 & 9.1 & 4.06 & 16 & 11 \\
S11.1 & EGYITDHMF & $1520-1528$ & 10.0 & 0.62 & 4.36 & 0 & 12 \\
S11.2 & GYITDHMFI & $1521-1529$ & 9.4 & 8.5 & 3.8 & 23 & 6 \\
\hline
\end{tabular}

${ }^{a}$ Escore de ligação ao MHC-I 1-10

${ }^{b}$ Escore de ligação ao MHC-I 1-31

Fonte: Medina-Armenteros (2012)

\subsection{Análise da resposta imune contra o peptídeo GM}

Uma vacina ideal contra a infecção por HRSV deve: reduzir a incidência e a severidade da doença provocada por HRSV de ambos grupos (A e B), em adultos e crianças; ser eficaz na presença de anticorpos maternais; e ser compatível com as vacinas pediátricas existentes. Igualmente importante, não deve induzir a patologia exacerbada quando o hospedeiro é infectado por vírus homólogo ou heterólogo. As abordagens de vacinação em camundongos com sucesso incluem vacinas de proteína purificada (Oien et al., 1994; Siegrist et al., 1999), vacinas de peptídeo (Bastien et al., 1999; Hsu et al., 1999), vírus vivo atenuado (Herlocher et al., 1999), e vacinas de DNA (Hsu et al., 1998; Li et al., 1998).

$\mathrm{Na}$ busca de imunógenos efetivos contra HRSV também estudamos a proteína G, pelo fato dela ser alvo da resposta imune humoral induzindo uma resposta de anticorpos neutralizantes. Trabalhamos especificamente com um peptídeo que abrange os resíduos 164 a 204, localizado no ectodomínio conservado da glicoproteína. Este peptídeo, GM, foi mutado nas posições 187,189 e 192 para eliminar o epítopo de células TCD4 (184-198) responsável pela resposta Th2 exagerada que acarreta a doença exacerbada com eosinofilia pulmonar (Tebbey et al., 1998).

A imunogenicidade do peptídeo foi avaliada utilizando diferentes abordagens. Uma delas consistiu na construção de vacinas de DNA inserindo a sequiência codificadora de GM em vetores de expressão eucariótica em fusão com a seqüência sinal do ativador de plasminogênio tecidual, e da subunidade B da toxina colérica (CTB), um potente adjuvante de mucosa. Também expressamos e purificamos o peptídeo GM em fusão com CTB, a partir 
de um vetor bacteriano. Assim, GM foi administrado como vacina de DNA (via intramuscular) ou proteína (vias intraperitoneal ou intranasal).

A estimulação da imunidade de mucosa contra o vírus é um aspecto crítico para o desenvolvimento de vacinas anti-HRSV. Foi observado que em humanos a administração intranasal de anticorpos monoclonais ou policlonais neutralizantes, levou a uma inibição pelo menos 160 vezes maior da infecção pulmonar por HRSV do que a administração parenteral, porém ambas foram efetivas (Prince et al., 1987). Ensaios clínicos de uma vacina de vírus vivo atenuado demonstraram que nos indivíduos vacinados, em que foi induzida uma resposta de IgA contra a proteína $\mathrm{G}$, houve proteção contra a infecção, enquanto naqueles em que não ocorreu essa resposta houve maior grau de infecção pelo vírus selvagem (Wright et al., 2000).

Nos dados aqui apresentados, para a imunização intranasal em camundongos, não foi observada resposta de anticorpos séricos ( $\operatorname{IgG}$ ) nem de mucosa ( $\operatorname{IgA}$ ) para nenhum grupo experimental (figuras 25 e 26, respectivamente). Inclusive, para a proteína de fusão GMCTB onde CTB deve funcionar como adjuvante de mucosa, direcionando o peptídeo GM para as células epiteliais do trato respiratório. Este efeito adjuvante da CTB, fusionado a ou coadministrado com um antígeno, já foi reportado (Arêas et al., 2004). Nesse caso a pentamerização da CTB é necessária para se ligar ao receptor GM1 presente na membrana das células epiteliais da mucosa. A formação de pentâmeros das proteínas CTB e GMCTB foi demonstrada por SDS-PAGE não desnaturante seguido de imunoblotting, bem como a capacidade delas de se ligarem ao GM1 como análise de funcionalidade (figura 22).

Inicialmente acreditamos que a ausência da resposta de anticorpos anti-GM podia se dever a um fenômeno de tolerância (Murphy et al., 2010), após a administração de 4 doses de antígeno. Para resolver essa questão, testamos a primeira coleta obtida 10 dias após a segunda dose. Foi obtido o mesmo resultado de não reatividade dos soros frente ao peptídeo GM sintético, ou seja não foram gerados anticorpos anti-GM IgG (séricos). Outro aspecto a levar em conta é o esquema de imunização empregado, sobre tudo com respeito à dose. Experimentos utilizando a CTB fusionada ao antígeno PsaA de Streptococcus pneumoniae inoculado por via intranasal levaram a uma resposta imune humoral de mucosa e sistêmica. No esquema de imunização foram administradas 6 doses do antígeno em 3 semanas, porém a quantidade foi bem menor $(1-4 \mu \mathrm{g}$ ) (Arêas et al., 2004). As quantidades altas de antígeno (CTB, 26,8 $\mu \mathrm{g}$; GM, $10 \mu \mathrm{g}$; CTB + GM, 26,8 $\mu \mathrm{g}$ e $10 \mu \mathrm{g}$, respectivamente; e GMCTB, 40 $\mu \mathrm{g})$ empregadas no nosso esquema de imunização podem ter levado ao desenvolvimento de tolerância contra o antígeno, daí a não detecção de anticorpos contra os imunógenos baseados 
em GM. Portanto, concluímos que a inoculação intranasal com as proteínas baseadas em GM não foi capaz de induzir resposta imune humoral tanto sistêmica quanto de mucosa, nas nossas condições experimentais.

A caracterização da resposta imune contra os peptídeos purificados revelou que as proteínas GM, GM+CTB e GMCTB, administradas via intraperitoneal, foram capazes de induzir resposta de anticorpos contra GM, de maneira específica. Apesar dos títulos altos apresentados, esses anticorpos, não se mostraram neutralizantes de HRSV, como era nossa expectativa. Outro dado a salientar é o fato de que não existem diferenças entre a resposta humoral frente às diferentes proteínas administradas via intraperitoneal $(\mathrm{GM}, \mathrm{GM}+\mathrm{CTB} \mathrm{e}$ GMCTB). Isto indica que a CTB não está funcionando como adjuvante, pelo menos por essa via. Por outro lado, a detecção de anticorpos nos soros de animais imunizados via intraperitoneal com os mesmos imunógenos utilizados na imunização intranasal, confirma o resultado de que o esquema de imunização usado por via intranasal não foi capaz de induzir uma resposta imune humoral.

A imunização com vetores eucarióticos revelou que apenas o plasmídio pTGMCTB, foi capaz de induzir resposta de anticorpos contra GM, de maneira específica. A falta de reatividade com GM dos soros de animais imunizados com pTCTB, bem como a confirmação da produção de anticorpos anti-CTB indicam que, os anticorpos gerados por pTGMCTB são específicos para GM. No caso do grupo imunizado com pTGM, a ausência de anticorpos reconhecendo GM é consistente com a falha na detecção de expressão de GM pelo plasmídio por imunofluorescência. Isso sugere que o peptídeo pT-GM ou não está sendo expresso eficientemente, ou que GM não está sendo exposto de forma a ser reconhecido pelo anticorpo utilizado para a detecção.

A capacidade de proteção frente a desafio com HRSV também não foi demonstrada, sendo que não houve redução da carga viral nos animais imunizados com os imunógenos baseados em GM (proteínas ou vacina de DNA), consistente com a falta de anticorpos neutralizantes. Além disso, a imunização com nenhum dos imunógenos induziu lesões severas ou moderadas após exposição ao vírus selvagem no desafio. A observação de lesões apenas discretas em animais imunizados com as proteínas contendo GM ou os plasmídios (pTGM, pTGMCTB) e desafiados vem reforçar o achado de que as mutações introduzidas (em azul) no epítopo de células TCD4+ (184-AICKRIPNKKPGKKT-198) em GM, eliminam a predisposição a desenvolver a doença exacerbada após exposição com HRSV selvagem (Tebbey et al., 1998). 
O peptídeo GM contem vários epítopos de células B murinas e humanas que mapeiam entre os aa 165-172, 171-187 e 196-204. Foi reportado que em camundongos Balb/c, esses anticorpos estão implicados na proteção do trato respiratório baixo (Plotnicky-Guilquin et al., 1999). Além disso, foi testada a capacidade protetora de um peptídeo sintético produzido em plantas da região entre os aa 170-191, o qual foi capaz de gerar imunidade tanto em mucosa quanto sistêmica (Belanger et al., 2000). Apesar destas evidências que motivaram a escolha do peptídeo GM como imunógeno, os nossos resultados mostram que o peptídeo GM só, ou no contexto da proteína de fusão GMCTB, não adquire uma conformação apropriada, capaz de induzir anticorpos neutralizantes. A ausência de anticorpos que bloqueiem a infecção viral explica a aparição de efeito citopático nos ensaios de neutralização e a carga viral alta nos grupos imunizados com GM.

A base para a proposta de vacinas de DNA, apresentada neste trabalho, é que após a inoculação do DNA plasmidial ocorre uma seqüência de eventos que levam à síntese intracelular do antígeno vacinal nas células APC estimulando, conseqüentemente, uma resposta imune humoral e celular específicas para o antígeno (Silva et al., 2005). Apesar da proteína GMCTB não ter gerado anticorpos neutralizantes contra HRSV, esperava-se uma redução na carga viral quando veiculada num plasmídio de expressão eucariótica, o que não foi constatado em nossos experimentos (figura 35). Essa expectativa vinha principalmente de um dado publicado anteriormente, em que uma vacina de DNA codificando para a proteína G integral foi capaz de induzir uma resposta de anticorpos neutralizantes e protetores em camundongos contra a infecção de trato respiratório baixo (Li et al., 2000). Assim, esperávamos dado similar para GM, e com a melhoria de estar lidando com uma região mais restrita e mais bem caracterizada da proteína $\mathrm{G}$, teoricamente diminuindo a possibilidade de induzir a patologia exacerbada quando o hospedeiro é infectado pelo vírus selvagem após a imunização. 


\section{CONCLUSÕES}

Os resultados aqui reportados indicaram que os peptídeos S8 e S11 foram capazes de induzir a liberação de IFN- $\gamma$ de maneira específica. A resposta imune celular foi constatada tanto no contexto da infecção viral, quanto quando esses peptídeos foram administrados como imunógenos, sendo maior no segundo caso. Peptídeos de 9 mer dentro dessas sequiências, restritos pelo haplótipo $\mathrm{H}-2^{\mathrm{d}}$ da molécula MHC-I, também induziram uma resposta de liberação de IFN- $\gamma$ específica. Portanto, concluímos que a proteína L do HRSV (polimerase viral) apresenta epítopos responsivos às células TCD8. Os cinco epítopos identificados são: S8.1 (IEPTYPHGL), S8.2 (TYPHGLRVV), S8.3 (GLRVVYESL), S11.1 (EGYITDHMF) e S11.2 (GYITDHMFI). Estamos em fase de caracterização de uma vacina múlti epítopos contra HRSV, incorporando os epítopos aqui identificados, para testar sua capacidade de proteção frente a desafio com HRSV.

Com respeito à proteína $\mathrm{G}$, foram construídos os vetores de expressão eucariótica baseados no peptídeo GM, pTGM e pTGMCTB, bem como os controles pT e pTCTB. As construções pTGMCTB e pTCTB funcionaram expressando as proteínas recombinantes correspondentes, enquanto para pTGM não foi possível detectar a expressão do peptídeo GM. Os dois plasmídios funcionais foram capazes de induzir uma resposta de anticorpos, porém, para o caso de pTGMCTB não são neutralizantes de HRSV, como era nossa expectativa. A imunização com as proteínas baseadas em GM (peptídeo sintético e GMCTB) induzem uma resposta humoral, porem os anticorpos também não são neutralizantes para HRSV. Concluímos que o peptídeo GM não adquire uma conformação adequada capaz de gerar anticorpos neutralizantes, quando está em fusão com a proteína CTB, tanto na forma de proteína de fusão, quanto como vacina de DNA. 


\section{REFERÊNCIAS}

American Academy of Pediatrics, COIDACOFAN. Revised indications for the use of palivizumab and respiratory syncytial virus immune globulin intravenous for the prevention of respiratory syncytial virus infections. Pediatrics. 2003;112(6):1442-6.

American Academy of Pediatrics, COIDACOFAN. Reassessment of the indications for ribavirin therapy in respiratory syncytial virus infections. American Academy of Pediatrics Committee on Infectious Diseases. Pediatrics. 1996;97(1):137-140.

Aherne W, Bird T, Court SD, Gardner PS, McQuillin J. Pathological changes in virus infections of the lower respiratory tract in children. J Clin Pathol. 1970;23(1):7-18.

Alexopoulou L, Holt AC, Medzhitov R, Flavell RA. Recognition of double-stranded RNA and activation of NF-kappaB by Toll-like receptor 3. Nature. 2001;413(6857):732-8.

Alwan WH, Kozlowski WJ, Openshaw PJ. Distinct types of lung disease caused by functional subsets of antiviral T cells. J Exp Med. 1994;179(1):81-9.

Alwan WH, Openshaw PJ. Distinct patterns of T- and B-cell immunity to respiratory syncytial vinis induced by individual viral proteins. Vaccine. 1993;11(4):431-7.

Alwan WH, Record FM, Openshaw PJ. Phenotypic and functional characterization of T cell lines specific for individual respiratory syncytial virus proteins. J. Immunol. 1993;150(12):5211-8.

Andersson C, Liljeström P, Ståhl S, Power UF. Protection against respiratory syncytial virus (RSV) elicited in mice by plasmid DNA immunisation encoding a secreted RSV G proteinderived antigen. FEMS Immunol Med Microbiol. 2000;29(4):247-53.

Anderson JJ, Serin M, Harrop J, Amin S, Toms GL, Scott R. Natural killer cell response to respiratory syncytial virus in the Balb/c mouse model. Adv Exp Med Biol. 1989;257:211-20.

Anderson LJ, Hierholzer JC, Tsou C, Hendry RM, Fernie BN, Stone Y et al. Antigenic characterisation of respiratory syncytial virus strains with monoclonal antibodies. J Infect Dis. 1985;151(4):626-33.

Arêas AP, Oliveira ML, Miyaji EN, Leite LC, Aires KA, Dias WO et al. Expression and characterization of cholera toxin B-pneumococcal surface adhesin A fusion protein in Escherichia coli: ability of CTB-PsaA to induce humoral immune response in mice. Biochem Biophys Res Commun. 2004;321(1):192-6.

Arêas AP, Oliveira ML, Ramos CRR, Sbrogio-Almeida ME, Raw I, Ho PL. Synthesis of cholera toxin B subunit gene: cloning and expression of a functional 6XHis-tagged protein in Escherichia coli. Protein Expr Purif. 2002;25(3):481-7.

Atreya PL, Kulkarni S. Respiratory syncytial virus strain A2 is resistant to the antiviral effects of type I interferons and human MxA. Virology. 1999;261(2):227-41.

De acordo com: International Committee of Medical Journal Editors.

Uniform requirements for manuscripts submitted to Biomedical Journal:

sample references. Available from: http://www.icmje.org [2007 May 22]. 
Bâchi T, Howe C. Morphogenesis and ultrastructure of respiratory syncytial virus. J Virol. 1973;12(5):1173-1180.

Bancroft GJ. The role of natural killer cells in innate resistance to infection. Curr Opin Immunol. 1993;5(4):503-10.

Barr F, Pedigo H, Johnson TR, Shepherd VL. Surfactant protein-A enhances uptake of respiratory syncytial virus by monocytes and U937 macrophages. Am J Respir Cell Mol Biol. 2000;23(5):586-92.

Bartz H, Turkel 0, Hoffjan S, Rothoeft T, Gonschorek A, Schauer U. Respiratory syncytial virus decreases the capacity of myeloid dendritic cells to induce interferon-gamma in naive $\mathrm{T}$ cells. Immunology. 2003;109(1):49-57.

Bastien N, Trudel M, Simard C. Complete protection of mice from respiratory syncytial virus infection following mucosal delivery of syntetic peptide vaccines. Vaccine. 1999;17(78):832-36.

Belanger H, Fleysh N, Cox S, Bartman G, Deka D, Trudel M et al. Human respiratory syncytial virus vaccine antigen produced in plants. FASEB J. 2000;14(14):2323-8.

Bembridge GP, Garcia-Beato R, López JA, Melero JA, Taylor G. Subcellular site of expression and route of vaccination infiuence pulmonary eosinophilia following respiratory syncytial virus challenge in $\mathrm{BALB} / \mathrm{c}$ mice sensitized to the attachment $\mathrm{G}$ protein. $\mathrm{J}$ lmmunol. 1998;161(5):2473-80.

Birnboim HC and Doly J. A rapid alkaline extraction procedure for screening recombinant plasmid DNA. Nucleic Acids Res. 1979;7(6):1513-23.

Bitko V, Shulyayeva O, Mazumder B, Musiyenko A, Ramaswamy M, Look DC et al. Nonstructural proteins of respiratory syncytial virus suppress premature apoptosis by an NFkappaB-dependent, interferon-independent mechanism and facilitate virus growth. $J$ Virol. 2007;81(4):1786-95.

Bryson DG, McNulty MS, Logan EF, Cush PF. Respiratory syncytial virus pneumonia in young calves: clinical and pathologic findings. Am J Vet Res. 1983;44(9):1648-55.

Carromeu C. Estudos de caraterização estrutural, localizaço intracelular e imunogenicidade da RNA polimerase do vírus respiratório sincicial humano [tese (Doutorado em Biotecnologia)]. Instituto de Ciências Biomédicas de São Paulo, Universidade de São Paulo, 2007.

Centers for Disease Control and Prevention (CDC). Respiratory syncytial virus activity: United States, 2003-2004. MMWR. 2004;53(49):1159-60.

Chang J, Braciale TJ. Respiratory syncytial virus infection suppresses lung CD8+ T-cell effector activity and peripheral CD8+ T-cell memory in the respiratory tract. Nat Med. 2002;8(1):54-60. 
Chang J, Srikiatkhachorn A, Braciale TJ. Visualization and characterization of respiratory syncytial virus F-specific CD8+ T cells during experimental virus infection. J Immunol. 2001;167(8):4254-60.

Chanock RM, Kapikian AZ, Mills J, Kim HW, Parrott RH. Influence of immunological factors in respiratory syncytial virus disease. Arch Environ Health. 1970;21(3):347-55.

Chanock RM, Roizman B, Myers M. Recovery from infants with respiratory illness of a virus related to chimpanzee coryza agent. I. Isolation, properties and characterization. Am J Hyg. 1957;66(3):281-290.

Cherrie AH, Anderson K, Wertz GW, Openshaw PJ. Human cytotoxic T cells stimulated by antigen on dendritic cells recognize the $\mathrm{N}, \mathrm{SH}, \mathrm{F}, \mathrm{M}, 22 \mathrm{~K}$, and $1 \mathrm{~b}$ proteins of respiratory syncytial virus. J Virol.1992;66(4):2102-10.

Collins PL, Murphy BR. New generation live vaccines against human respiratory syncytial virus designed by reverse genetics. Proc Am Thrc Soc. 2005;2(2):166-73.

Collins PL, Chanock RM, Murphy BR. Respiratory syncytial virus. In: Knipe DM, Howley, PM, editors. Fields Virology, $4^{\text {th }}$ ed. Philadelphia; Lippincott, Williams \& Wilkins; 2001.vol.2. p.1443-85.

Collins PL, Mottet G. Membrane orientation and oligomerization of the small hydrophobic protein of human respiratory syncytial virus. J Gen Virol. 1993;74(7):1445-50.

Connors M, Giese NA, Kulkarni AB, Firestone C-Y, Morse HC, and Murphy BR. Enhanced pulmonary histopathology induced by respiratory syncytial virus (HRSV) challenge of formalin-inactivated HRSV-immunized BALB/c mice is abrogated by depletion of IL-4 and IL-10. J Virol. 1994;68(8):5321-25.

Cristina J, López JA, Albó C, Garcia-Barreno B, García J, Melero JA et al. Analysis of genetic variability in human respiratory syncytial virus by the RNase A mismatch cleavage method: subtype divergence and heterogeneity. Virology 1990;174(1):126-34.

Crowe JE Jr, Firestone CY, Murphy BR. Passively acquired antibodies suppress humoral but not cell-mediated immunity in mice immunized with live attenuated respiratory syncytial virus vaccines. J Immunol. 2001;167(7):3910-18.

Crowe JE Jr. Host responses to respiratory virus infection and immunization. Curr Top Microbiol Immunol. 1999;236:191-214.

Dagouassat N, Robillard V, Haeuw JF, Plotnicky-Gilquin H, Power UF, Corvaia N et al. A novel bipolar mode of attachment to aluminium-containing adjuvants by BBG2Na, a recombinant subunit HRSV vaccine. Vaccine. 2001;19(30):4143-52.

de Graaff PM, de Jong EC, van Capel TM, van Dijk ME, Roholl PJ, Boes J et al. Respiratory syncytial virus infection of monocyte-derived dendritic cells decreases their capacity to activate CD4 T cells. J Immunol. 2005;175(9):5904-11. 
de Graaff PM, Heidema J, Poelen MC, van Dijk ME, Lukens MV, van Gestel SP et al. HLADP4 presents an immunodominant peptide from the RSV G protein to CD4 T cells. Virology. 2004;326(2):220-30.

De Groot AS. Immunomics: discovering new targets for vaccines and therapeutics. Drug Discov Today. 2006;11(5-6):203-9.

De Groot AS, Berzofsky JA. From genome to vaccine - new immunoinformatics tools for vaccine design. Methods. 2004;34(4):425-28.

De Groot AS, Saint-Aubin C, Bosma A, Sbai H, Rayner J, Martin W. Rapid determination of HLA B*07 ligands from the West Nile virus NY99 genome. Emerg Infect Dis. 2001;7(4): 706-13.

de Jong EC, Smits HH, Kapsenberg ML. Dendritic cell-mediated T cell polarization. Springer Semin Immunopathol. 2005;26(3):289-307.

de Waal L, Yüksel S, Brandenburg AH, Langedijk JP, Sintnicolaas K, Verjans GM et al. Identification of a common HLA-DP4-restricted T-cell epitope in the conserved region of the respiratory syncytial virus G protein. J Virol. 2004;78(4):1775-81.

DuBridge R B, Tang P, Hsia H C, Leong PM, Miller J H, Calos M P. Analysis of mutation in human cells by using an Epstein-Barr virus shuttle system. Mol Cell Biol. 1987;7(1):379-87.

Falsey AR, Hennessey PA, Formica MA, Cox C, Walsh EE. Respiratory syncytial virus infection in elderly and high-risk adults. N Engl J Med. 2005;352(17):1749 -59.

Falsey AR, Walsh EE. Relationship of serum antibody to risk of respiratory syncytial virus infection in elderly adults. J Infect Dis. 1998;177(2):463-6.

Feldman SA, Hendry RM, Beeler JA. Identification of a linear heparin binding domain for human respiratory syncytial virus attachment glycoprotein G. J Virol. 1999;73(8):6610-7.

Ferron F, Longhi S, Henrissat B, Canard B. Viral RNA-polymerase-a predicted 2'-O-ribose methyltransferase domain shared by all Mononegavirales. Trends Biochem Sci. 2002;27(5): 222-4.

Follet EA, Pringle CR, Pennington TH. Virus development in enucleated cells: echovirus, poliovirus, pseudorabies virus, reovirus, respiratory syncytial virus and Semliki Forest virus. J Gen Virol. 1975;26(2):183-96.

Gaddum RM, Cook RS, Wyld SG, Lopez JA, Bustos R, Melero JA et al. Mutant forms of the $\mathrm{F}$ protein of human respiratory syncytial (RS) virus induce a cytotoxic $\mathrm{T}$ Iymphocyte response but not a neutralizing antibody response and only transient resistance to RS virus infection. J Gen Virol. 1996;77(6):1239-48.

Garcia-Barreno B, Delgado T, Melero JA. Oligo(A) sequences of human respiratory syncytial virus $\mathrm{G}$ protein gene: assessment of their genetic stability in frameshift mutants. J Virol. 1994;68(9):5460-68. 
García-Barreno B, Jorcano JL, Aukenbauer T, López-Galíndez C, Melero JA. Participation of cytoskeletal intermediate filaments in the infectious cycle of human respiratory syncytial virus (RSV). Virus Res. 1988;9(4):307-21.

Ghildyal R, Hartley C, Varrasso A, Meanger J, Voe1ker DR, Anders EM et al. Surfactant protein A binds to the fusion glycoprotein of respiratory syncytial virus and neutralizes virion infectivity. J Infect Dis. 1999;180(6):2009-13.

Glezen WP, Paredes A, Allison JE, Taber LH, Frank AL. Risk of respiratory syncytial virus infection for infants from low-income farnilies in relationship to age, sex, ethnic group, and maternal antibody level. J Pediatr.1981;98(5):708-15.

Godefroy S, Goestch L, Plotnicky-Gilquin H, Nguyen TN, Schmitt D, Staquet MJ et al. Immunization onto shaved skin with a bacterial enterotoxin adjuvant protects mice against respiratory syncytial virus (rsv).Vaccine. 2003;2(15):1665-71.

Graham BS, Bunton LA, Wright PF, Karzon DT. Role of T-Iymphocyte subsets in the pathogenesis of primary infection and rechallenge with respiratory syncytial virus in mice. $\mathrm{J}$ Clin Invest. 1991;88(3):1026-33.

Hall CB. Nosocomial respiratory syncytial virus infections: the "Cold War" has not ended. Clin Infect Dis. 2000;31(2):590-6.

Hall CB, Walsh EE, Long CE, Schnabel KC. Immunity to and frequency of reinfection with respiratory syncytiat virus. J Infect Dis. 1991;163(4):693-8.

Hancock GE, Speelman DJ, Heers K, Bortell E, Smith J, Cosco C. Generation of atypical pulmonary inflammatory responses in BALB/c mice after immunization with the native attachment (G) glycoprotein of respiratory syncytial virus. J Virol. 1996;70(11):7783-91.

Harlow E, Lane D. Antibodies: a laboratory manual. New York: Cold spring Harbor Laboratory Press; 1988.

Henderson FW, Collier AM, Clyde WA, Denny FW. Respiratory syncytial virus infections, reinfections and immunity: a prospective, longitudinal study in young children. N Engl J Med. 1979;300(10):530-4.

Herd KA, Mahalingam S, Mackay IM, Nissen M, Sloots TP, Tindle RW. Cytotoxic Tlymphocyte epitope vaccination protects against human metapneumovirus infection and disease in mice. J Virol. 2006;80(4):2034-44.

Herlocher M L, Ewasyshyn M, Sambhara S, Gharaee-Kermani M, Cho D, Lai J et al. Immunological properties of plaque purified strains of live attenuated respiratory syncytial virus (RSV) for human vaccine. Vaccine. 1999;17(2):172-81.

Hickling TP, Bright H, Wing K, Gower D, Martin SL, Sim RB et al. A recombinant trimeric surfactant protein $\mathrm{D}$ carbohydrate recognition domain inhibits respiratory syncytial virus infection in vitro and in vivo. Eur J Immunol. 1999;29(11):3478-84. 
Hoffman SJ, Laham FR, Polack FP. Mechanisms of illness during respiratory syncytial virus infection: the lungs, the virus and the immune response. Microb Infect. 2004;6(8):767-72.

Holberg CJ, Wright AL, Martínez FD, Ray CG, Taussig LM, Lebowitz MD. Risk factors for respiratory syncytial virus-associated lower respiratory illnesses in the first year of life. Am J Epidemiol. 1991;133(11):1135-51.

Hsu SC, Chargelegue D, Obeid OE, Steward MW. Synergistic effect of immunization with a peptide cocktail inducing antibody, helper and cytotoxic T-cell responses on protection against respiratory syncytial virus. J Gen Virol. 1999;80(6):1401-5.

Hsu SC, Obeid OE, Collins M, Igbal M, Chargelegue D, Steward MW. Protective cytotoxic T lymphocyte responses against paramyxoviruses induced by epitope-based DNA vaccines: involvement of IFN- $\gamma$. Int Immunol. 1998;10(10):1441-7.

Hussell T, Openshaw PJ. Intracellular TFN-gamma expression in natural killer cells precedes lung CD8 + T cell recruitment during respiratory syncytial virus infection. J Gen Virol. 1998;79(11):2593-601.

Isaacs, D. Viral subunit vaccines. Lancet 1991;337(8751):1223- 4.

Johnson TR, Teng MN, Collins PL, Graham BS. Respiratory syncytial virus (RSV) G glycoprotein is not necessary for vaccine-enhanced disease induced by immunization with formalin-inactivated RSV. J Virol. 2004a;78(11):6024-32.

Johnson TR, Varga SM, Braciale TJ, Graham BS. Vbeta14(+) T cells mediate the vaccineenhanced disease induced by immunization with respiratory syncytial virus (RSV) G glycoprotein but not with formalin-inactivated RSV. J Virol. 2004b;78(16):8753-60.

Johnson TR and Graham BS. Secreted respiratory syncytial virus G glycoprotein induces interleukin-5 (IL-5), IL-13, and eosinophilia by an IL-4-independent mechanism. J Virol. 1999; 73(10):8485-95.

Johnson TR, Johnson JE, Roberts SR, Wertz GW, Parker RA, Graham BS. Priming with secreted glycoprotein G of respiratory syncytial virus (HRSV) augments interleukin-5 production and tissue eosinophilia after HRSV challenge. J Virol. 1998;72(4):2871-80.

Karron RA, Buonagurio DA, Georgiu AF, Whitehead SS, Adamus JE, Clements-Mann M L. Respiratory syncytial virus (RSV) SH and G proteins are not essential for viral replication in vitro: clinical evaluation and molecular characterization of a cold-passaged, attenuated RSV subgroup B mutant. Proc Natl Acad Sci USA. 1997;94(25):13961-6.

Kerr MH, Paton JY. Surfactant protein levels in severe respiratory syncytial virus infection. Am J Respir Crit Care Med. 1999;159(4):1115-8.

Kim HW, Canchola JG, Brandt CD, Pyles G, Chanock RM, Jensen K et al. Respiratory syncytial virus disease in infants despite prior administration of antigenic inactivated vaccine. Am J Epidemiol. 1969;89(4):422- 34. 
Kochenderfer JN, Chien CD, Simpson JL, Gress RE. Maximizing CD8+ T cell responses elicited by peptide vaccines containing $\mathrm{CpG}$ oligodeoxynucleotides. Clin Immunol. 2007;124(2):119-30.

Kochenderfer JN, Chien CD, Simpson JL, Gress RE. Synergism between CpG-containing oligodeoxynucleotides and IL-2 causes dramatic enhancement of vaccine-elicited CD8+ T cell responses. J Immunol. 2006;177(12):8860-73.

Kos FJ, Engleman EG. Immune regulation: a critical link between NK cells and CTLs. Immunol Today. 1996;17(4):174-6.

Krilov LR, Anderson LJ, Marcoux L, Bonagura VR, Wedgwood JF. Antibody-mediated enhancement of respiratory syncytial virus infection in two monocyte/macrophage cell lines. J Infect Dis. 1989;160(5):777-82.

Kulkarni AB, Collins PL, Bacik I, Yewdell JW, Bennink JR, Crowe JE Jr et al. Cytotoxic T cells specific for a single peptide on the M2 protein of respiratory syncytial virus are the sole mediators of resistance induced by immunization with $\mathrm{M} 2$ encoded by a recombinant vaccinia virus. J Virol. 1995;69(2):1261-4.

Kulkarni AB, Morse HC 3rd, Bennink JR, Yewdell JW, Murphy BR. Immunization of mice with vaccinia virus-M2 recombinant induces epitope-specific and cross-reactive $\mathrm{Kd}$ restricted CD8+ cytotoxic T cells. J Virol.1993;67(7):4086-92.

Kurt-Jones EA, Popova L, Kwinn L, Haynes LM, Jones LP, Tripp RA et al. Pattern recognition receptors TLR4 and CD 14 mediate response to respiratory syncytial virus. Nat Immunol 2000; 1(5):398-401.

Laemmli UK. Cleavage of structural proteins during the assembly of the head of bacteriophage T4. Nature.1970;227(5259):680-5.

Langedijk JP, de Groot BL, Berendsen HJ, van Oirschot JT. Structural homology of the central conserved region of the attachment protein $\mathrm{G}$ of respiratory syncytial virus with the fourth subdomain of 55-kDa tumor necrosis factor receptor. Virology. 1998;243(2):293-302.

Lee S, Miller SA, Wright DW, Rock MT, Crowe JE Jr. Tissue-Specific Regulation of CD8+ T Lym Lymphocyte Immunodominance in Respiratory Syncytial Virus Infection. J Virol. 2006;81(5):2349-58.

Levine S, Klaiber-Franco R, Paradiso PR. Demonstration that glycoprotein $G$ is the attachment protein of respiratory syncytial virus. J Gen Virol 1987;68(9):2521-4.

Li X, Sambhara S, Li CX, Ettorre L, Switzer I, Cates G et al. Plasmid DNA encoding the respiratory syncytial virus $G$ protein is a promising vaccine candidate. Virology. 2000;269(1):54-65.

Li X, Sambhara S, Li CX, Ewasyshyn M, Parrington M, Caterini J et al. Protection against respiratory syncytial virus infection by DNA immunization. J. Exp. Med. 1998;188(4):681-8. 
Liu Y, Xu L, Jiang Y, Sun J, He X. Phenotypic and functional analysis of LCMV gp33-41specific CD8 $\mathrm{T}$ cells elicited by multiple peptide immunization in mice revealed the upregulation of PD-1 expression on antigen-specific CD8 T cells. Cell Mol Immunol. 2007;4(6):431-7.

Liuzzi M, Mason SW, Cartier M, Lawetz C, McCollum RS, Dansereau N et al. Inhibitors of respiratory syncycial virus replication target cotranscriptional mRNA guanylylation by viral RNA-dependent RNA polimerase. J Virol. 2005;79(20):13105-15.

Lodmell DL, Ray NB, Ulrich JT, Ewalt LC. DNA vaccination of mice against rabies virus: effects of route of vaccination and the adjuvant monophsophoryl lipid A (MPL). Vaccine. 2000;18:(11-12):1059-66.

Lukens MV, Claassen EA, de Graaff PM, van Dijk ME, Hoogerhout P, Toebes M, et al. Characterization of the CD8+ $\mathrm{T}$ cell responses directed against respiratory syncytial virus during primary and secondary infection in C57BL/6 mice. Virology. 2006;352(1):157-68.

Martínez I, Valdés O, Delfraro A, Arbiza J, Russi J, Melero JA. Evolutionary pattern of the $\mathrm{G}$ glycoprotein of human respiratory syncytial virus from antigenic group B: the use of alternative termination codons and lineage diversification. J Gen Virol. 1999;80(1):125-30.

Martínez I, Melero JA. Enhanced neutralization of human respiratory syncytial virus by mixtures of monoclonal antibodies to the attachment $(\mathrm{G})$ glycoprotein. J Gen Virol 1998;79(9):2215-20.

Martínez I, Dopazo J, Melero JA. Antigenic structure of the human respiratory syncytial virus $\mathrm{G}$ glycoprotein and relevance of hypermutation events for the generation of antigenic variants. J Gen Virol. 1997;78(10):2419-29.

McIntosh K, Masters HB, Orr I, Chao RK, Barkin RM. The immunologic response to infection with respiratory syncytial virus in infants. J Infect Dis. 1978;138(1):24-32.

Melero JA. "Molecular Biology of Human Respiratory Syncytial Vírus". In: Arie J Zuckerman, Royal Free and Univerisity college medical school, editors. Perspectives in medical virology. Oxford: Elsevier; 2007. p.1-42.

Melero JA, García-Barreno B, Martínez I, Pringue CR, Cane PA. Antigenic structure, evolution and immunobiology of human respiratory syncytial virus attachement $(\mathrm{G})$ protein. J Gen Virol 1997;78(10):2411-18.

Mills J 5th, Van Kirk JE, Wright PF and Chanock RM. Experimental respiratory syncytial virus infection of adults: possible mechanisms of resistance to infection and illness. $\mathrm{J}$ Immunol. 1971;107(1):123-30.

Mink MAO, Stec OS, Collins PL. Nucleotide sequence ofthe 3' leader and 5' trailer regions of human respiratory syncytial virus genomic RNA. Virology. 1991;185(2):615-24.

Mok H, Lee S, Wright DW, Crowe JE Jr. Enhancement of the CD8+ T cell response to a subdominant epitope of respiratory syncytial virus by deletion of an immunodominant epitope. Vaccine. 2008;26(37):4775-82. 
Monick MM, Yarovinsky TO, Powers LS, Butler NS, Carter AB, Gudmundsson G et al. Respiratory syncytial virus up-regulates TLR4 and sensitizes airway epithelial cells to endotoxin. J Biol Chem. 2003;278(52):53035-44.

Moore AE, Sabachewsky L, Toolan HW. Culture characteristics of four permanent lines of human cancer cells. Cancer Res. 1955;15(9)598-602.

Mufson MA, Orvell C, Rafnar B, Norrby E. Two distinct subtypes of human respiratory syncytial virus. J Gen Virol. 1985;66(10):2111-24.

Murphy K, Travers P, Walport M. "O sistema imune de mucosa" In: Imunobiologia de Janeway. 7th ed., Porto Alegre: Artmed, 2010. p. 457-493.

Murphy BR, Alling DW, Snyder MH, Walsh EE, Prince GA, Chanock RM et al. Effect of age and preexisting antibody on serum antibody response of infants and children to the $F$ and $\mathrm{G}$ glycoproteins during respiratory syncytial virus infection. $\mathrm{J}$ Clin Microbiol. 1986a;24(5):894-8.

Murphy BR, Prince GA, Walsh EE, Kim HW, Parrott RH, Hemming VG et al. Disassociation between serum neutralisng and glycoprotein antibody responses of infants and children who received inactivated respiratory syncytial virus vaccine. J Clin Microbiol 1986b;24(2):197-202.

Neilson KA, Yunis EJ. Demonstration of respiratory syncytial virus in an autopsy series. Pediatr Pathol. 1990;10(4):491-502.

Ogilvie MM, Vathenen AS, Radford M, Codd J, Key S. Maternal antibody and respiratory syncytial virus infection in infancy. J Med Virol. 1981;7(4):263-71.

Oien NL, Brideau RJ, Walsh EE, Wathen MW. Induction of local and systemic immunity against human respiratory syncytial virus using a chimeric FG glycoprotein and cholera toxin B subunit. Vaccine. 1994;12(8):731-5.

Olson MR, Varga SM. CD8 T cells inhibit respiratory syncytial virus (RSV) vaccineenhanced disease. J Immunol. 2007;179(8):5415-24.

Openshaw PJ, Culley FJ, Olszewska W. Immunopathogenesis of vaccine-enhanced RSV disease. Vaccine. 2001;20(1):27-31.

Orvell C, Norrby E, Mufson MA. Preparation and characterization of monoclonal antibodies directed against five structural components of human respiratory syncytial virus subgroup B. J Gen Virol. 1987;68(12):3125-35.

Paramore LC, Ciuryla V, Ciesla G, Liu L. Economic impact of respiratory syncytial virusrelated illness in the US: an analysis of national databases. Pharmacoeconomics. 2004;22(5):275-84. 
Plotnicky-Guilquin H, Goestch L, Huss T, Champion T, Beck A, Haeuw JF. Identification of multiple protective epitopes (protectopes) in the central conserved domain of a prototype human respiratory syncytial virus G protein. J Virol. 1999;73(7):5637-45.

Poch 0, Blumberg BM, Bougueleret L, Tordo N. Sequence comparison of tive polymerases ( $\mathrm{L}$ proteins) of unsegmented negative-strand RNA viruses: theoretical assignment of functional domains. J Gen Virol. 1990;71(5):1153-62.

Poch 0, Sauvaget I, Delarue M, Tordo N. Identification of four conserved motifs among the RNA-dependent polymerase encoding elements. EMBO J. 1989;8(12):3867-74.

Polack FP, lrusta PM, Hoffman SJ, Schiatti MP, Melendi GA, Delgado MF et al. The cysteine-rich region of respiratory syncytial virus attachment protein inhibits innate immunity elicited by the virus and endotoxin. Proc Natl Acad Sci USA 2005;102(25):89969001.

Polack FP, Teng MN, Collins PL, Prince GA, Exner M, Regele H et al. A role for immune complexes in enhanced respiratory syncytial vinis disease. J Exp Med. 2002;196(6):859-65.

Prince GA, Hemming VG, Horswood RL, Baron PA, Chanock RM. Effectiveness of topically administered neutralizing antibodies in experimental immunotherapy of respiratory syncytial virus infection in cotton rats. J Virol. 1987;61(6):1851-4.

Ramaswamy M, Shi L, Varga SM, Barik S, Behlke MA, Look DC. Respiratory syncytial virus nonstructural protein 2 specifically inhibits type I interferon signal transduciton. Virology. 2006;344(2):328-39.

Rammensee H, Bachmann J, Emmerich NN, Bachor OA, Stevanovic S. SYFPEITHI: database for MHC ligands and peptide motifs. Immunogenetics. 1999;50(3-4):213-9.

Rammensee HG, Falk K, Rötzschke O. Peptides naturally presented by MHC class I molecules. Annu. Rev. Immunol. 1993,11:213-44.

Richardson LS, Yolken RH, Belshe RB, Camargo E, Kim HW, Chanock RM. Enzymelinked immunosorbent assay for measurement of serological response to respiratory syncytial virus infection. Infect lmmunol. 1978;20(3):660-4.

Roberts SR, Lichtenstein D, Ball LA, Wertz GW. The membrane-associated and secreted forms of the respiratory syncytial virus attachment glycoprotein $\mathrm{G}$ are synthesized from alternative initiation codons. J Virol. 1994;68(7):4538-46.

Rodriguez WJ, Gruber WC, Groothuis JR, Simoes EA, Rosas AJ, Lepow M et al. Respiratory syncytial virus immune globulin treatment of RSV lower respiratory tract infection in previously healthy children. Pediatrics. 1997;100(6):937-42.

Romagnani S. Induction of TH1 and TH2 responses: a key role for the 'natural' immune response? Immunol Today. 1992;13(10):379-81. 
Rutigliano JA, Rock MT, Johnson AK, Crowe JE Jr, Graham BS. Identification of an H2D(b)-restricted CD8 + cytotoxic T Iymphocyte epitope in the matrix protein of respiratory syncytial virus. Virology. 2005;337(2):335-43.

Sakurai H, Williamson RA, Crowe JE, Beeler JA, Poignard P, Bastidas RB et al. Human antibody responses to mature and immature forms of viral envelope in respiratory syncytial virus infection: significance for subunit vaccines. J Virol. 1999;73(4):2956-62.

Sambrook J, Fritsch EF, Maniatis T. Molecular Cloning a laboratory manual, 2nd ed. USA: Cold Spring Harbor Laboratory Press; 1989. 3v.

Schlender J, Bossert B, Buchholz U, Conzelmann KK. Bovine respiratory syncytial virus nonstructural proteins NS I and NS2 cooperatively antagonize alpha/beta interferon induced antiviral response. J Virol. 2000;74(18):8234-42.

Schwarze J, Hamelmann E, Bradley KL, Takeda K, Gelfand EW. Respiratory syncytial virus infection results in airway hyperresponsiveness and enhanced airway sensitization to allergen. J Clin Invest. 1997;100(1):226-33.

Siegrist CA, Plotnicky-Gilquin H, Córdova M, Berney M, Bonnefoy JY, Nguyen TN et al. Protective efficacy against respiratory syncytial virus following murine neonatal immunization with BBG2Na vaccine: influence of adjuvants and maternal antibodies. J Infect Dis. 1999;179(6):1326-33.

Silva CL, Bonato VL, Coelho-Castelo AA, De Souza AO, Santos SA, Lima KM et al. Immunotherapy with plasmid DNA encoding mycobacterial hsp65 in association with chemotherapy is a more rapid and efficient form of treatment for tuberculosis in mice. Gene Ther. 2005;12(3):281-7.

Simmons CP, Dong T, Chau NV, Dung NT, Chau TN, Thao le TT et al. Early T-Cell Responses to Dengue Virus Epitopes in Vietnamese Adults with Secondary Dengue Virus Infections. J.Virol. 2005;79(9):5665-75.

Simmons CP, Hussell T, Sparer T, Walzl G, Openshaw P, Dougan G. Mucosal delivery of respiratory syncytial virus CTL peptide with enterotoxin-based adjuvants elicits protective, immunopathogenic, and immunoregulatory antiviral CD8+ $\mathrm{T}$ cell responses. J Immunol. 2001;166(2):1106-13.

Simoes EA. Respiratory syncytial virus infection. Lancet. 1999;354(9181):847-52.

Spann KM, Tran KC, Chi B, Rabin R, Collins PL. Suppression of the induction of alpha, beta and lambda interferons by the NS 1 and NS2 proteins of human respiratory syncytial virus in human epithelial cells and macrophages. J Virol. 2004;78(8):4363-69.

Sparer TE, Matthews S, Hussell T, Rae Al, Garcia Barreno B, Melero JA et al. Eliminating a region of respiratory syncytial virus attachment protein allows induction of protective immunity without vaccine-enhanced lung eosinophilia. J Exp Med. 1998;187(11):1921-6. 
Stec DS, Hill MG 3rd, Collins PL. Sequence analysis of the polymerase L gene of human respiratory syncytial virus and predicted phylogeny of nonsegmented negative-strand viruses. Virology. 1991;183(1):273-87.

Stein RT, Sherrill D, Morgan WJ, Holberg CJ, Halonen M, Taussig LM et al. Respiratory syncytial virus in early life and risk of wheeze and allergy by age 13 years. Lancet. 1999;354(9178):541-5.

Taylor G. "Immunology of RSV". In: Arie J Zuckerman , Royal Free and Univerisity college medical school, editors. Perspectives in medical virology, I4. Oxford: Elsevier; 2007. p.43-87.

Taylor G. The role of antibody in controlling and/or clearing virus infections. In: A da GL, editor. Strategies vaccine design. Austin, TX, Landes Company; 1994; p. 17.

Taylor G, Stott EJ, Furze J, Ford J, Sopp P. Protective epitopes on the fusion protein of respiratory syncytial virus recognized by murine and bovine monoclonal antibodies. J Gen Virol. 1992;73(9):2217-23.

Taylor CE, Craft AW, Kernahan J, Millman R, Reid MM, Scott R et al.. Local antibody production and respiratory syncytial virus infection in children with leukaemia. J Med Virol. 1990;30(4):277-81.

Tayyari F, Marchant D, Moraes T J, Duan W, Mastrangelo P, Hegele R G. Identification of nucleolin as a cellular receptor for human respiratory syncytial virus. Nat Med. 2011;17(9):1132-5.

Tebbey PW, Hagen M, Hancock GE. Atypical pulmonary eosinophilia is mediated by a specific amino acid sequence of the attachment (G) Protein of Respiratory Syncytial Virus. J Exp Med. 1998;188(10):1967-72.

Teng MN, Whitehead SS, Collins PL. Contribution of the respiratory syncytial vinis G glycoprotein and its secreted and membrane-bound forms to virus replication in vitro and in vivo. Virology. 2001;289(2):283-96.

Thomas LH, Stott EJ, Collins AP, Jebbett J. Experimental pneumonia in gnotobiotic calves produced by respiratory syncytial virus. Br J Exp Pathol 1984;65(1):19-28.

Tripp RA, Jones LP, Haynes LM, Zheng H, Murphy PM, Anderson LJ. CX3C chemokine mimicry by respiratory syncytial virus G glycoprotein. Nat Immunol. 2001;2(8):732-8.

Tripp RA, Jones L, Anderson LJ. Respiratory syncytial virus G and/or SH glycoproteins modify $\mathrm{CC}$ and CXC chemokine mRNA expression in the BALB/c mouse. J Virol. 2000;74(3):6227-9.

Tripp R, Moore D, Jones L, Sullender W, Winter J, Anderson LJ. Respiratory syncytial virus $\mathrm{G}$ and/or SH protein alters Th 1 cytokines, natural killer cells, and neutrophils responding to pulmonary infection in BALB/c mice. J Virol. 1999;73(9):7099-107. 
Viuff B, Uttenthal A, Tegtmeier C, Alexandersen S. Sites of replieation of bovine respiratory syncytial virus in naturally infected ealves as determined by in situ hybridisation. Vet Pathol. 1996;33(4):383-90.

Voges B, Vallbracht S, Zimmer G, Bossow S, Neubert WJ, Richter K, et al. Recombinant Sendai virus induces $\mathrm{T}$ cell immunity against respiratory syncytial virus that is protective in the absence of antibodies. Cell Immunol. 2007;247(2):85-94.

Walsh EE, Hruska J. Monoclonal antibodies to respiratory syncytial virus proteins: identification of the fusion protein. J Virol. 1983;47(1):171-77.

Waris ME, Tsou C, Erdman DD, Zaki SR, Anderson LJ. Respiratory syncytial virus infection in BALB/ c mice previously immunized with formalin-inactivated virus induces enhanced pulmonary inflammatoryresponse with a predominant Th2-like cytokine pattern. J Virol. 1996;70(5):2852-60.

Watt PJ, Zardis M, Lambden PR. Age related IgG subclass response to respiratory syneytial virus fusion protein in infected infants. Clin Exp Immunol. 1986;64(3):503-9.

Welliver Re, Kaul TN, Putnam TI, Sun M, Riddlesberger K, Ogra PL. The antibody response to primary and seeondary infeetion with respiratory syncytial virus: kinetics of class-specific responses. J Pediatr. 1980;96(5):808-13.

Wright PF, Karron RA, Belshe RB, Thompson J, Crowe JE Jr, Boyce TG et al. Evaluation of a live, coldpassaged, ternperature-sensitive, respiratory syncytial virus vaccine candidate in infancy. J Infect Dis. 2000;182(5):1331-42.

Yu JR, Kim S, Lee JB, Chang J. Single intranasal immunization with recombinant adenovirus-based vaccine induces protective immunity against respiratory syncytial virus infection. J Virol. 2008;82(5):2350-7.

Zhang LG, Srinivasan KN, Veeramani A, August JT and Brusic V. PRED ${ }^{\text {Balb/c }}$ : a system for the prediction of pptide binding to $\mathrm{H} 2^{\mathrm{d}}$ molecules, a haplotype of the Balb/c mouse. Nucleic Acid Res 2005;33 (Web Server issue):180-183.

Zhang L, Peeples ME, Boucher RC, Collins PL, Pickles RJ. Respiratory syncytial virus infection of human airway epithelial cells is polarized, specific to ciliates cells, and without obvious cytopathology. J Virol. 2002;76(11):5654-66. 